UNIVERSIDADE ESTADUAL PAULISTA “JÚLIO DE MESQUITA FILHO” FACULDADE DE CIÊNCIAS AGRONÔMICAS CAMPUS DE BOTUCATU

\title{
GEOPROCESSAMENTO APLICADO AO ZONEAMENTO AGRÍCOLA PARA CANA-DE-AÇÚCAR IRRIGADA DO ESTADO DO PIAUÍ
}

CLESCY OLIVEIRA DA SILVA

Tese apresentada à Faculdade de Ciências Agronômicas da UNESP - Campus de Botucatu, para obtenção do Título de Doutora em Agronomia (Irrigação e Drenagem).

BOTUCATU - SP

Fevereiro - 2016 
UNIVERSIDADE ESTADUAL PAULISTA “JÚLIO DE MESQUITA FILHO” FACULDADE DE CIÊNCIAS AGRONÔMICAS

CAMPUS DE BOTUCATU

\section{GEOPROCESSAMENTO APLICADO AO ZONEAMENTO AGRÍCOLA PARA CANA-DE-AÇÚCAR IRRIGADA DO ESTADO DO PIAUÍ}

\section{CLESCY OLIVEIRA DA SILVA}

Orientador: Prof. Dr. Sérgio Campos

Tese apresentada à Faculdade de Ciências

Agronômicas da UNESP - Campus de Botucatu, para obtenção do Título de Doutora em Agronomia (Irrigação e Drenagem).

BOTUCATU - SP

Fevereiro - 2016 
FICHA CATALOGRÁFICA ELABORADA PELA SEÇÃO TÉCNICA DE AQUISIÇÃO E TRATAMENTO DA INFORMAÇÃO - DIRETORIA TÉCNICA DE BIBLIOTECA E DOCUMENTAÇÃO - UNESP - FCA - LAGEADO - BOTUCATU (SP)

5586g Geoprocessamento aplicado ao zoneamento agrícola para cana-de-açúcar irrigada do estado do Piauí / Clescy oliveira da Silva. - Botucatu : [s.n.], 2016

ix, $72 \mathrm{f}$. : fots. color.; grafs. color., tabs.

Tese (Doutorado) - Universidade Estadual Paulista, Faculdade de Ciências Agronômicas, Botucatu, 2016

orientador: Sérgio Campos

Inclui bibliografia

1. Cana-de-açúcar - Irrigação. 2. Balanço hídrico. 3. Sistemas de informação geográfica. I. Campos, Sérgio. II. Universidade Estadual Paulista "Júlio de Mesquita Filho" (Câmpus de Botucatu). Faculdade de Ciências Agronômicas. III. Título. 


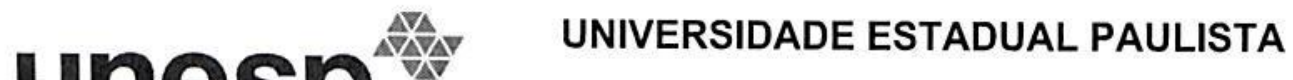 \\ Câmpus de Botucatu}

\section{CERTIFICADO DE APROVAÇÃO}

TÍTULO DA TESE: GEOPROCESSAMENTO APLICADO AO ZONEAMENTO AGRÍCOLA DA CANA-DE-AÇÚCAR IRRIGADA DO ESTADO DO PIAUI.

\section{AUTORA: CLESCY OLIVEIRA DA SILVA ORIENTADOR: SÉRGIO CAMPOS}

Aprovada como parte das exigências para obtenção do Titulo de Doutora em AGRONOMIA (IRRIGAÇÃO E DRENAGEM), pela Comissão Examinadora:

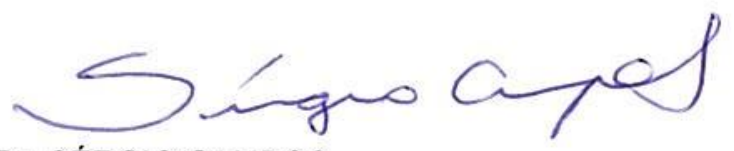

Prof. Dr. SÉRGIO CAMPOS

Depto de Engenharia Rural / Faculdade de Ciências Agrônomica - UNESP

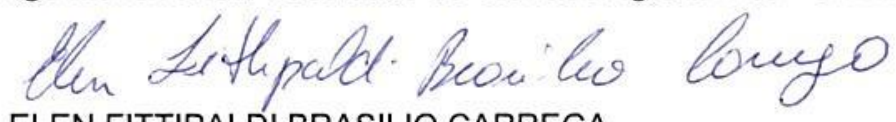

Profa. Dra. ELEN FITTIPALDI BRASILIO CARREGA

Depto de Educação Física / FACULDADES INTEGRADAS DE BOTUCATU - UNIFAC

Katael Celore Mon in.

Prof. Dr. RAFAEL CALORE NARDINI

Depto de Agronomia / Faculdade Eduvale de Avaré

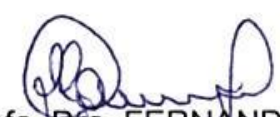

Profa. Dra. FERNANDA LEITE RIBEIRO

Depto de Geociências / UNIVERSIDADE ESTADUAL DE LONDRINA - UEL

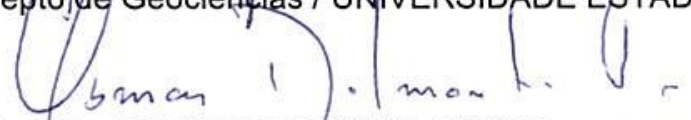

Prof. Dr. OSMAR DELMANTO JUNIOR

Depto de Agronegócios / FACULDADE DE TECNOLOGIA DE BOTUCATU

Botucatu, 19 de fevereiro de 2016. 
Aos meus pais, Maria das Graças Oliveira e Antonio José Silva pela dedicação de uma vida e amor incondicional.

Às minhas famílias Oliveira e Oliveira por todo apoio e incentivos constantes. 


\section{AGRADECIMENTOS}

Ao Senhor da vida e do amor por me proporcionar todo o suporte emocional que precisei para encarar mais esse grande desafio, guiando cada passo dado. E por colocar cada pessoa abaixo citadas, que foram essenciais.

À Faculdade de Ciências Agronômicas (UNESP - FCA), campus Botucatu, por todo o suporte técnico e físico.

Ao orientador, professor Dr. Sérgio Campos pela acolhida, paciência e acreditação no meu desempenho na realização desse trabalho.

Ao professor Dr. Francisco Edinaldo Mousinho, pela humildade, amizade, disponibilidade, orientações e sugestões que muito contribuíram para a elaboração desse trabalho.

À minha amiga/prima Simone Raquel Oliveira, pelos anos de amizade, e por ter me conduzido no universo agronômico de forma sábia e amiga. Muito do que escrevi foi por acreditar em suas palavras.

Aos queridos amigos: Angélica de Deus, Lima, João Queluz, Mariana de Campos, Milena Lozano, Ramilos Brito e Edilson Ramos pelos ensinamentos compartilhados, companheirismo, risos e brincadeiras que tornaram a minha estadia tão agradável.

Aos amigos/irmãos Raimundo Monteiro, Franciana Sousa, Bruna Soldera, Géssica Lima, Joselina Correia e Yara Garcia, por todo amor fraternal dedicado e experiências compartilhadas, que levarei comigo.

Aos funcionários e docentes do programa de pós-graduação do departamento de Engenharia Rural pela atenção dada dentro e fora do horário, sempre com cordialidade e dedicação.

À Fundação Capes pelo suporte financeiro para o desenvolvimento desse trabalho e meu aperfeiçoamento profissional.

Às famílias Oliveira e Oliveira pelo amor, paciência, dedicação, suporte e por sempre me motivarem seguir, não importando as pedras encontradas no caminho.

À minha "Ohana", Franklin e Helena, que me ensinaram o que é amor incondicional. Sou grata por cada momento juntos, e pelas "injeções" de ânimo dadas. 
"Ora, a fé é a certeza daquilo que esperamos e a prova das coisas que não vemos".

Hebreus 11:1 


\section{SUMÁRIO}

RESUMO. .1

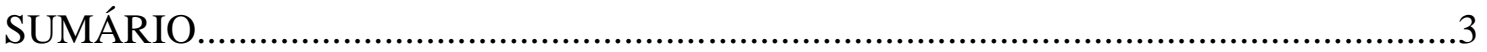

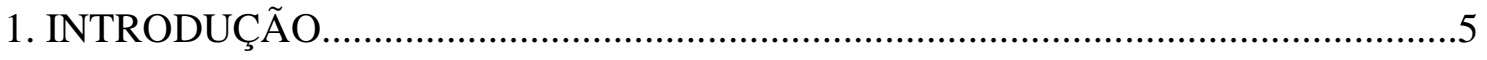

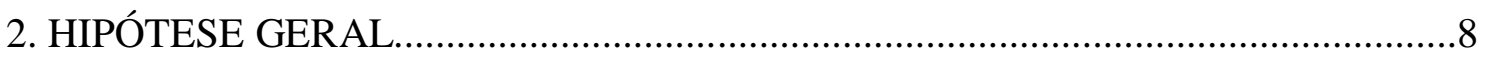

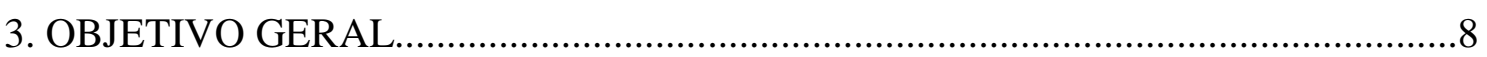

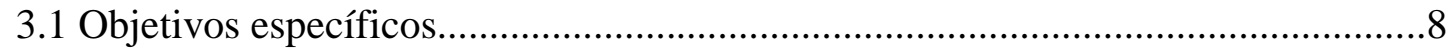

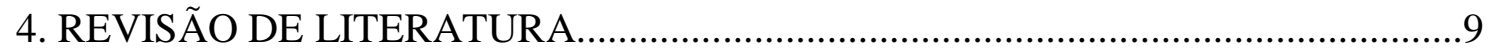

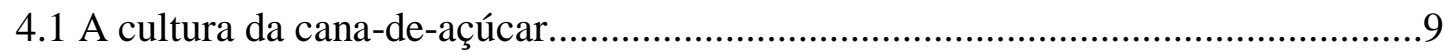

4.2 Necessidade hídrica da cana-de-açúcar..........................................................11

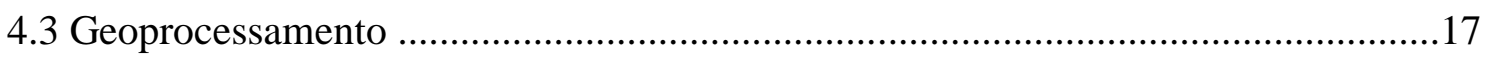

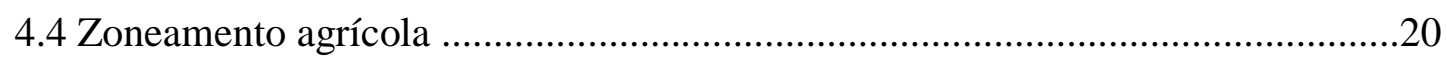

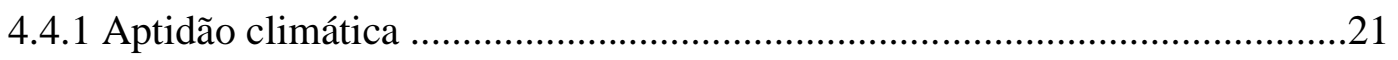

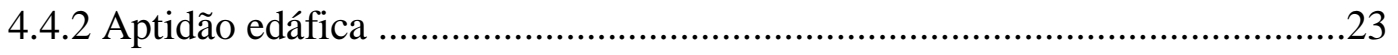

4.4.3 Balanço hídrico da cultura ...................................................................25

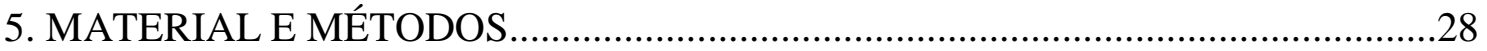

5.1 Caracterização da área de estudo.....................................................................28

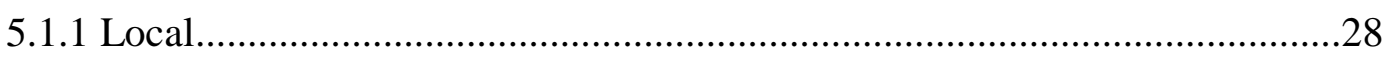

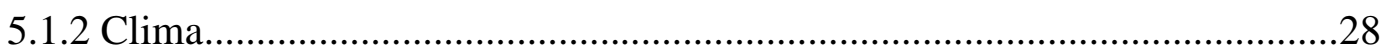

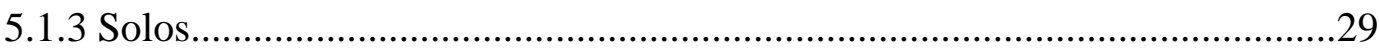

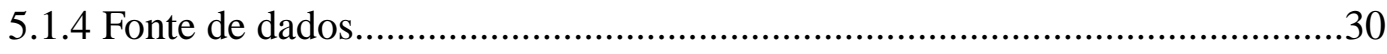

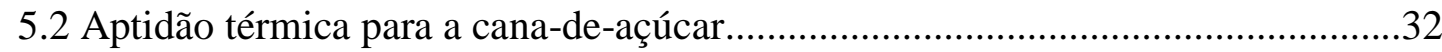

5.3 Aptidão edáfica para fins de mecanização ...........................................................32

5.4 Estimativa de lâmina de irrigação para cana-de-açúcar .....................................33

5.5 Zoneamento agrícola para cana-de-açúcar irrigada ..........................................36

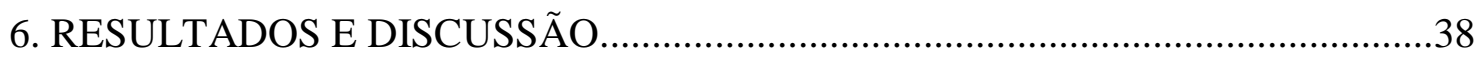

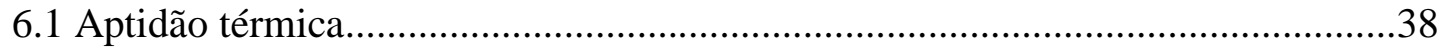

6.2 Aptidão para fins de mecanização agrícola - declividade.....................................43

6.3 Lâmina bruta de irrigação por gotejamento.........................................................46

6.4 Zoneamento agrícola da cana-de-açúcar irrigada .............................................59

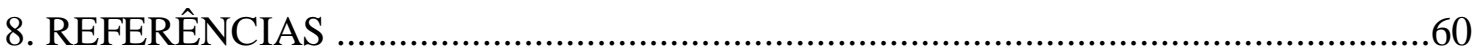

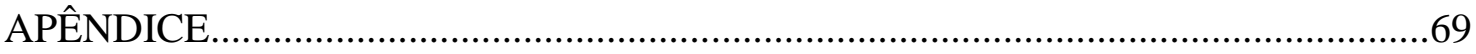




\section{LISTA DE FIGURAS}

Figura 1 - Disposição geográfica dos postos pluviométricos utilizados no cálculo do balanço hídrico diário da cultura

Figura 2 - Gráfico de temperatura média do ar mensal para o estado do Piauí ........................38

Figura 3 - Mapa de temperatura média do ar anual para o estado do Piaúi ....................40

Figura 4 - Mapa temático de aptidão térmica para cana-de-açúcar do estado do Piauí............41

Figura 5 - Mapa temático de aptidão para fins de mecanização para cana-de-açúcar no estado

do Piauí

Figura 6 - Percentuais de área do Estado do Piauí referentes às classes de lâminas brutas de irrigação da cana-de-açúcar em solos com capacidade de água disponível de $75 \mathrm{~mm}$, para cada data de plantio

Figura 7 - Percentuais de área do estado do Piauí referentes às classes de lâminas brutas de irrigação da cana-de-açúcar em solos com capacidade de água disponível de $100 \mathrm{~mm}$, para cada data de plantio.

Figura 8 - Percentuais de área do estado do Piauí referentes às classes de lâminas brutas de irrigação da cana-de-açúcar em solos com capacidade de água disponível de $125 \mathrm{~mm}$, para cada data de plantio.

Figura 9 - Mapa das mesoregiões do estado do Piauí.

Figura 10 - Espacialização de lâmina bruta de irrigação por gotejamento, da cana-deaçúcar, especializadas para 12 meses de plantio em solos com capacidade de água disponível de $75 \mathrm{~mm}$, para o estado do Piauí.

Figura 11 - Espacialização de lâmina bruta de irrigação por gotejamento, da cana-deaçúcar, especializadas para 12 meses de plantio em solos com capacidade de água disponível de $100 \mathrm{~mm}$, para o estado do Piauí.

Figura 12 - Espacialização de lâmina bruta de irrigação por gotejamento, da cana-deaçúcar, especializadas para 12 meses de plantio em solos com capacidade de água disponível de $125 \mathrm{~mm}$, para o estado do Piauí.

Figura 13 - Zoneamento agrícola para a cana-de-açúcar irrigada, para 12 meses de plantio em solos com capacidade de água disponível de $75 \mathrm{~mm}$, para o estado do Piauí 
Figura 14 - Zoneamento agrícola para a cana-de-açúcar irrigada, para 12 meses de plantio em solos com capacidade de água disponível de $100 \mathrm{~mm}$, para o estado do Piauí. .57

Figura 15 - Mapa do zoneamento agrícola para a cana-de-açúcar irrigada, para 12 meses de plantio em solos com capacidade de água disponível de $155 \mathrm{~mm}$, para o estado do Piauí. .58 


\section{LISTA DE TABELAS}

Tabela 1 - Valores de referência considerados para diversos parâmetros na definição

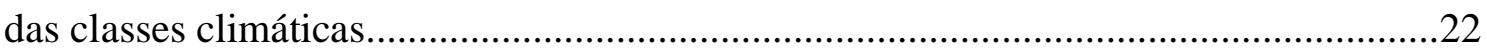
Tabela 2 - Valores de coeficientede cultura (kc) nas respectivas fases de

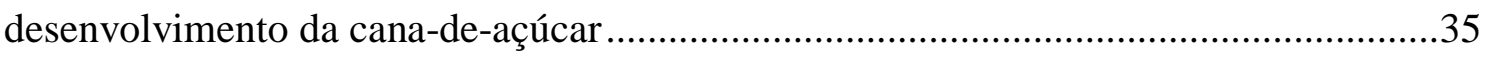


GEOPROSSAMENTO APLICADO AO ZONEAMENTO AGRÍCOLA PARA CANADE-AÇÚCAR IRRIGADA DO ESTADO DO PIAUÍ, Botucatu, 2016.57p. Tese (Doutorado em Agronomia/Irrigação e Drenagem) - Faculdade de Ciências Agronômicas, Universidade Estadual Paulista "Júlio de Mesquita Filho".

Autor: CLESCY OLIVEIRA DA SILVA

Orientador: Dr. SÉRGIO CAMPOS

\section{RESUMO}

O trabalho teve como objetivo principal espacializar parâmetros edafoclimáticos da cana-de-açúcar e suas respectivas lâminas brutas de irrigação. $\mathrm{O}$ zoneamento agrícola da cana-de-açúcar irrigada foi elaborado seguindo quatro etapas. A primeira etapa foi a confecção do mapa temático de temperatura média do ar, indicando os locais com aptidão térmica $\left(\mathrm{Tm}>21^{\circ} \mathrm{C}\right)$ para todo o Estado do Piauí. A segunda etapa foi a elaboração do mapa de declividade indicando as áreas aptas declividade abaixo de 12\%, para fins de mecanização, utilizando mosaicos de imagens SRTM. A terceira foi a elaboração de mapas de lâminas brutas de irrigação para todo o ciclo da cana-de-açúcar com base no balanço hídrico da cultura, utilizando uma série histórica de 15 anos, com dados diários de precipitação, de 87 locais de postos pluviométricos, disponibilizado pelo INMET (Instituto Nacional de Meteorologia) e a SUDENE (Superintendência do Desenvolvimento do Nordeste), localizados no Piauí e em Estados vizinhos. Foram estabelecidas 12 meses de plantio (janeiro a dezembro), para cada CAD analisada $(75 \mathrm{~mm}, 100 \mathrm{~mm}$ e $125 \mathrm{~mm})$, totalizando 36 mapas de lâminas bruta de irrigação. A evapotranspiração de referência (ETo) diária foi estimada pelo método de Thornthwaite (1948), para todos os 87 locais dos postos pluviométricos. De posse dos dados do balanço hídrico da cultura, os valores de lâminas brutas foram calculados levando em consideração o sistema de irrigação por gotejamento. Como resultado, se obteve mapas com percentuais de área do Estado e seus respectivos intervalo de classes de lâmina de irrigação. O balanço hídrico da cultura foi processado por meio da ferramenta "Macros" do Excel 2013, em planilhas eletrônicas. A análise estatística realizada no balanço hídrico da cultura, seguiu o método de Monte Carlo. A quarta etapa foi o cruzamento dos mapas de aptidão térmica, aptidão para mecanização e 
lâminas brutas de irrigação, resultando no zoneamento de agrícola para cana-de-açúcar irrigada. O programa de SIG utilizado para a confecção de todos os mapas contidos nesse trabalho foi o Quantum Gis® 2.8.2. O Estado do Piauí não possui restrições térmicas para o cultivo da cana-de-açúcar. O Piauí tem extensas áreas potencialmente aptas a mecanização agrícola. Os melhores meses de plantio com o menor consumo de lâmina bruta de irrigação, em geral, foram observados no período seco da região. $\mathrm{O}$ zoneamento agrícola da cultura da cana-de-açúcar irrigada indicou áreas aptas e inaptas para fins de mecanização agrícola, e os meses de plantio em que há um consumo de lâmina bruta para irrigação por gotejamento.

Palavras chaves: Balanço hídrico da cultura, temperatura média do ar, lâmina bruta de irrigação, SIG. 


\section{GEOPROCESSING APPLIED TO AGRICULTURAL ZONING OF SUGARCANE}

PIAUI STATE, Botucatu, 2016. 86 p. Tese (Doutorado em Agronomia/Irrigação e

Drenagem) - Faculdade de Ciências Agronômicas, Universidade Estadual Paulista

"Júlio de Mesquita Filho".

Author: CLESCY OLIVEIRA DA SILVA

Adviser: Dr. SÉRGIO CAMPOS

\section{SUMMARY}

The work aimed to spatialise edaphoclimatic parameters of sugarcane and their gross irrigation levels. The agricultural zoning for sugarcane irrigation was developed following four steps. The first step was the preparation of thematic map of average air temperature, indicating the locations with thermal fitness $\left(\mathrm{Tm}>21^{\circ} \mathrm{C}\right)$ throughout the state of Piauí. The second step was the preparation of the slope map indicating areas suitable slope below $12 \%$ for mechanization purposes, using SRTM images mosaics. The third was the development of gross irrigation depth maps for the entire cycle of sugarcane based on the water balance of the culture, using a historical series of 15 years, with daily rainfall data from 87 local rain gauge stations, provided by INMET (National Meteorological Institute) and SUDENE, located in Piaui and neighboring states. 12 months plantations were established (January to December), for each CAD analyzed $(75 \mathrm{~mm}, 100 \mathrm{~mm}$ and $125 \mathrm{~mm})$, totaling 36 maps of gross irrigation levels. The reference evapotranspiration (ETo) daily was estimated by Thornthwaite method (1948) for all 87 locations of rainfall stations. Having the data of the water balance of culture, the values of gross blades were calculated taking into account the drip irrigation system. As a result, if obtained maps of the area percentages of the state and their range of water depth classes. The water balance of the crop was processed through the tool "Macros" Excel 2013 for spreadsheets. Statistical analysis in the water balance of culture, followed the Monte Carlo method. The fourth step was the crossing of thermal maps fitness, fitness for mechanization and gross irrigation levels, resulting in agricultural zoning for sugarcane irrigated. The GIS software used for making all the maps contained in this work is the Quantum Gis® 2.8.2. The state of Piauí does not have thermal constraints for the cultivation of sugarcane. Piauí has 
extensive potentially suitable areas to agricultural mechanization. The best months for planting with the lowest consumption of raw water depth generally were observed in the dry season in the region. The agricultural zoning of sugarcane irrigated indicated areas suitable and unsuitable for the purpose of agricultural mechanization, and the months of planting that there is a consumption of raw blade to drip irrigation.

Keywords: culture water balance, average air temperature, gross irrigation depth, GIS 


\section{INTRODUÇÃO}

A cana-de-açúcar no Brasil, tem a finalidade de atender, em sua maioria, a produção do etanol (álcool usado como combustível) e de açúcar, uma parcela menor é destinada a fabricação de bebida alcoólica (aguardente) e alimentação de animais.

Atualmente, o Brasil é o maior produtor de cana-de-açúcar a nível mundial, com uma área total cultivada de aproximadamente 9,7 milhões de hectares e uma produção anual de 708,3 milhões de toneladas, gerando reflexos importantes na economia brasileira, no ano de 2015 (IBGE, 2015). O país é responsável por mais da metade da comercialização do açúcar no mundo e líder na produção do etanol. Estima-se que até 2019 o mesmo possa alcançar 32,6 milhões de toneladas de açúcar para exportação e 58,8 bilhões de litros de etanol produzido para consumo do mercado interno e externo, valor esse considerado o dobro da produção registrada em 2008 (BRASILa, 2015).

A cultura da cana-de-açúcar no Nordeste vem se expandindo devido às crescentes necessidades do setor energético, o que leva a uma demanda de tecnologias para o aumento de sua produtividade na região. Segundo Datagro (2014) a produção do Nordeste não pode ser ignorada, pois é responsável por $10 \%$ da produção brasileira, o equivalente à metade da produção da Tailândia.

Devido ao aumento do valor do petróleo e à preocupação em buscar energias com menor grau de prejuízo ambiental, o Brasil vê a necessidade de 
substituição do combustível fóssil por biocombustíveis para suprimento do mercado interno e a oportunidade de conquistar mercados externos.

A expansão de novas áreas para o cultivo de cana-de-açúcar trouxe a necessidade de se subsidiar o planejamento da ocupação pela cultura de forma adequada, no que se refere à produtividade e as questões sócio-ambientais. O Ministério da Agricultura, Pecuária e Abastecimento (MAPA) elaborou um planejamento por meio da adoção do Zoneamento Agroecológico da Cana-de-Açúcar (ZAE-Cana) que indica áreas de expansão da cultura de forma sustentável, o qual foi aprovado e encontra-se em vigor pelo Decreto n ${ }^{\circ}$ 6.961, de 17 de setembro de 2009, publicado no Diário Oficial da União de 18 de setembro de 2009 (BRASIL, 2012),

A elaboração do ZAE-Cana, proposto pelo MAPA, indica uma avaliação do potencial das terras para a produção da cultura da cana-de-açúcar em regime de sequeiro, e uma irrigação por salvamento de até $50 \mathrm{~mm}$, numa produção sustentável, com solos aptos, baixo risco climático e que permite manejo mecanizado sem a queima da cana. Dessa forma, exclui algumas áreas com potencial de solo e clima, mas com restrição ambiental, e as áreas de irrigação acima de $50 \mathrm{~mm}$.

Um projeto em execução pela Embrapa, coordenado por Antonio Santiago, pesquisador da Embrapa Tabuleiro Costeiros, intitulado de Produção sustentável da cana-de-açúcar, considera as áreas dos estados de Tocantins, Maranhão e Piauí como áreas promissoras de expansão, quando se leva em consideração suas características de solo e clima como, também, pelas condições de logística e distribuição para atendimento da demanda do mercado externo, que facilitam o rápido escoamento do produto final, chegando ao consumidor com a qualidade exigida pelo mercado internacional (CNPTIA, 2015).

De fato, na safra 2014/2015, os estados do Piauí, Maranhão e Tocantins responderam por apenas $7,9 \%$ da produção nordeste de cana-de-açúcar (2,3 milhões de toneladas), em uma área cultivada de aproximadamente 98 mil hectares, com rendimento médio de 190,5 t.ha ${ }^{-1}$ (IBGEb, 2015). Ainda analisando a mesma fonte de dados, esse rendimento é inferior à média nacional, porém, superior à média regional, o que demonstra o potencial edafoclimático da região para a produção de cana-de-açúcar, desde que os principais fatores limitantes à produção sejam eliminados com o uso de tecnologias, como a adoção da irrigação e fertirrigação. 
No caso específico do Piauí, de acordo Manzato et al. (2009), as áreas potenciais ao cultivo da cana-de-açúcar que possuem características físicas do solo, de relevo e topografia favorável, situam-se em regiões com regime climático semiárido e sub-úmido seco. Andrade Júnior et al. (2012) ressaltam que com uma precipitação variando de 800 a 1.200 mm anuais, cuja magnitude e distribuição espacial é insuficiente, a mesma não satisfaz a exigência hídrica da cultura de forma adequada durante o todo o seu ciclo, passando por períodos longos de estresse hídrico no solo.

A irrigação aplicada à cana-de-açúcar é realizada por diversos métodos, dentre eles, o que tem mais se destacado é a irrigação localizada (gotejamento subsuperficial). Esse sistema, segundo Andrade Júnior et al. (2012) é um dos mais eficientes, pois reduz a evaporação da água e danos mecânicos ao sistema, há uma menor interferência com os tratos culturais, favorece a colheita mecanizada e tem a melhor eficiência na aplicação da fertirrigação. O planejamento adequado da irrigação localizada e da fertirrigação tem proporcionado um crescimento na produção de até mais de 100\%, conforme estudos realizado no Estado, pela Embrapa Meio-Norte.

Nesse sentido, dado o potencial edafoclimático do estado do Piauí para a produção de cana-de-açúcar sob regime de irrigação plena e com base em resultados locais de pesquisa, e a pouca informação técnica e científica sobre a cultura irrigada, torna-se fundamental um zoneamento que relacione informações edafoclimáticas com a adoção da prática da irrigação localizada, permitindo identificar as diferentes regiões, dentro do Estado, e suas respectivas lâminas de irrigação. Atualmente, os zoneamentos agrícolas para cana-de-açúcar elaborados para o Piauí contemplam apenas regiões com possibilidade de cultivo de cana-de-açúcar sob condição de sequeiro, ou seja, em áreas onde o único suprimento hídrico para a cultura ocorre via precipitação pluvial. 


\section{HIPÓTESE GERAL}

O estado do Piauí, considerado por muitos como a última fronteira agrícola do país, possui grande potencial para o cultivo da cana-de-açúcar irrigada devido às suas condições edafotérmicas favoráveis à cultura.

\section{OBJETIVO GERAL}

- Espacialização de parâmetros edafotérmicos, como elaboração do zoneamento agrícola da cana-de-açúcar irrigada no estado do Piauí.

\subsection{Objetivos específicos:}

- Elaborar mapa temático de aptidão térmica para a cana-de-açúcar irrigada no estado do Piauí;

- Elaborar mapa de aptidão para fins de mecanização para a cana-deaçúcar irrigada no estado do Piauí;

- Espacializar as regiões de lâminas de irrigação para a cana-de-açúcar no estado do Piauí;

- Espacializar as regiões com aptidão térmica e para mecanização da canade-açúcar irrigada. 


\section{REVISÃO DE LITERATURA}

\subsection{A cultura da cana-de-açúcar}

A cana-de-açúcar é uma gramínea pertencente à família Poaceae, originária do sudoeste da Ásia. É uma planta que serve como fonte para produção de açúcar, biocombustível (álcool etílico) entre outros.

De acordo com França \& Jasinski (2007), a cana-de-açúcar tem como características: caule em forma de colmos, inflorescência, folhas com bainhas abertas e lâminas de sílicas nas bordas. É uma cultura semiperene e pode ser plantada em três épocas diferentes: sistema de ano-e-meio (cana de 18 meses), sistema de ano (cana de 12 meses) e plantio de inverno, sendo que se for feita uma fertirrigação com vinhaça, ou mesmo irrigação, o plantio da cana pode ocorrer em todo o ano (ROSSETTO, 2014).

Estudos têm comprovado que o comportamento do crescimento radicular da cana-de açúcar se difere conforme o tipo de variedade, a disponibilidade hídrica, o estado e tipo de solo, misturas de fertirrigação, assim como, as condições climáticas do local. Quando há um maior enraizamento da cana, maior será a sua capacidade de absorver nutriente, sua disponibilidade hídrica e exploração do solo (MEDINA et al., 2002).

Vasconcelos e Dinardo-Miranda (2010) afirmam que existem variedades com maior concentração de raízes na superfície e outras, com distribuição mais uniforme em profundidade, e que após período de seca, tem variedades, que 
retomam rapidamente o crescimento radicular por ocasião do restabelecimento da umidade do solo, enquanto em outras variedades essa reestruturação é mais lenta.

Faroni (2005), analisando o sistema radicular de cana-de-açúcar e identificando raízes metabolicamente ativas, de um canavial em Piracicaba, SP, observou que em um Latossolo Vermelho, a variedade RB85-5156 concentrou 75\% de seu sistema radicular em $20 \mathrm{~cm}$ de profundidade do perfil do solo, embora as raízes tenham alcançado $80 \mathrm{~cm}$. Costa et al. (2007), avaliando a distribuição radicular da cana, em Porto Feliz, SP, observaram que em Latossolo Vermelho Amarelo, as variedades RB83-5486 e RB83-5089, apresentaram maior concentração de raízes em 54 cm de profundidade no perfil do solo. Quando se analisou a cultivar RB83-5486, em um Neossolo Vermelho, o sistema radicular apresentou maior concentração em $46 \mathrm{~cm}$ de profundidade.

A prática de plantio da cana, comumente utilizada no Brasil é a propagação vegetativa de estacas ou toletes, contendo duas ou três gemas. Fernandes (2009) analisando diferentes formas de plantio da cana em Campo de Goytacazes, RJ, verificou que o plantio com colmos inteiros, com palha e ponta é o mais recomendado, pois se tem uma maior economia de mão-de-obra, no plantio, e sua produção não diferiu das outras formas (colmo inteiro com palha e sem ponta, colmo inteiros sem palha e sem ponta, e colmo picado sem palha e sem ponta). Townsend (2000), recomenda que as mudas venham de canaviais vigorosos, sem pragas e doenças, que tenha entre oito e 12 meses de idade, sendo submetidas a tratamentos com fungicidas e inseticidas antes do plantio.

Assim como em outras culturas, a cana-de-açúcar, desde de sua produção para comercialização, passou por melhoramentos em suas variedades, objetivando variedades mais resistente a doenças, pragas, e as condições de solo e clima da região. Landell et al. (2005) relatam que essa prática é bastante antiga e que a prioridade, na época, era por varietais que apresentassem maior teor de sacarose, merecendo destaque a espécie Saccharum officinarum (cana nobre), que até o início do século XX era responsável por grande parte da matéria-prima mundial, através de variedades como Bourbon. Marin (2015) cita 115 variedades de cana-de-açúcar mais difundidas atualmente no Brasil, distribuídas por centros de pesquisa, divididas em: Planalsucar (Programa Nacional de Melhoramento da Cana-de Açúcar) - Ridesa (Rede 
Interuniversitária de Desenvolvimento do Setor Sucroalcooleiro) (RB), Copersucar (SP) - CTC (Centro de Tecnologia Canavieira), e IAC (Instituto Agronômico).

Cultivada desde a colonização, a cana-de-açúcar, no Brasil, recebeu uma atenção maior, a nível de produção, por volta da metade do século XVI, no Nordeste brasileiro (Alagoas, Bahia, Paraíba, Pernambuco e Sergipe). Atualmente, o Brasil é o número um no ranking da produção mundial de cana, responsável por mais da metade do açúcar comercializado no mundo, e o primeiro na de etanol, conquistando a cada dia, mais mercado externo com a difusão do biocombustível como fonte alternativa de energia (MAPA, 2015).

Na safra 2013/2014 a região Centro-Sul do Brasil, foi a que mais produziu cana-de-açúcar, responsável por quase $90 \%$ de toda a produção, restando apenas $10 \%$ para a região Norte-Nordeste (UNICA, 2015). Nessa mesma consulta de safra, os únicos Estados da federação que não apareceram como produtores de cana-deaçúcar foram Amapá e Roraima, para a unidade de mil toneladas. O Piauí contribui com $1,6 \%$ da produção brasileira, mesmo havendo um crescimento entre as safras de 2013/2014 e 2014/2015 de 1.800 toneladas. Ao todo, são 59 municípios produtores de cana no Estado, se destacando o município de União com 336.494 toneladas, seguido por José de Freitas com 229.219 toneladas, no ano de 2014 (IBGE, 2014).

\subsection{Necessidades hídricas da cana-de-açúcar}

Os vegetais possuem em sua composição cerca de $80 \%$ a $95 \%$ de água (LACERDA, ENÉAS FILHO, PINHEIRO, 2007). Dessa forma, a água desempenha um papel fundamental para a ocorrência de reações bioquímicas em seu metabolismo e na composição da massa de seus tecidos, se tornando indispensável para a germinação e desenvolvimento dos mesmos.

De acordo com Marin (2014), a Organização das Nações Unidas para a Agricultura e Alimentação (FAO) indica que a necessidade hídrica da cana-deaçúcar vai de 1.500 a $2.500 \mathrm{~mm}$, essa necessidade deve suprida de maneira uniforme durante todo o período de desenvolvimento vegetativo da cultura. No entanto, o autor relata que estudos recentes identificaram que a cana exige uma necessidade hídrica em torno de 1.200 a $1.300 \mathrm{~mm}$ para atingir seu máximo potencial. 
Bernardo (2008), afirma que na agricultura irrigada, deve-se otimizar o uso do fator "água", para que os demais fatores de produção possam ser melhor utilizados, resultando em altos índices de produtividade, com uma melhor combinação dos insumos aplicados. $\mathrm{O}$ autor ressalta que o conhecimento dos efeitos da lâmina total aplicada, precipitação e irrigação, sobre a produtividade da cana-de-açúcar são fundamentais para auxiliar na tomada de decisão, buscando o manejo racional da cultura.

Hernandez (2006) afirma que o uso da irrigação na cana-deaçúcar será benéfico e necessário quanto maior for o período (número de meses do ano) de déficit hídrico no solo. O mesmo autor ressalta que comparada ao cultivo de sequeiro, a irrigação terá melhor desempenho em solo mais arenoso onde a cana estiver cultivada, pois esses solos possui uma menor capacidade para armazenamento de água e chuvas intensas em um curto período pode não garantir a quantidade de água necessária a cultura. A irrigação, também, favorece um melhor estabelecimento da cana recémplantada, dessa forma pode haver uma antecipação da colheita, maior produtividade, aumento da expectativa da vida útil do canavial, passando de 5 para 8 a 10 anos para que se inicie um novo plantio.

Segundo Dalri et al. (2008), a ampliação de área cultivadas não está necessariamente relacionada ao aumento da produção de cana-de-açúcar no Brasil, mesmo com a disponibilidade de expansão das terras cultiváveis. Os pesquisadores apontam como alternativa viável o desenvolvimento de novas variedades que respondam bem à irrigação, uma vez que a produtividade média brasileira é de 78,6 t.ha ${ }^{-}$ ${ }^{1}$ (IBGE, 2010), muito distante ainda do potencial produtivo biológico da cultura.

Para a expansão do cultivo sustentável do manejo irrigado da cana-de-açúcar no Brasil é fundamental políticas locais ou regionais, que apoiem financeiramente à pesquisa da irrigação em cultivares de cana de alto potencial de produção para a região. Atualmente, com a importância que a cultura tem assumido devido ao programa de agroenergia do Governo Federal, tem-se constatado incremento nos trabalhos de pesquisa que visam quantificação de lâmina de irrigação e seus efeitos em variedades de cana que tenham alto potencial de produção, atingindo valores competitivos de mercado. Definindo, assim, o manejo da irrigação que deva ser praticado, tendo com base a disponibilidade de água nas mais diversas regiões, e a variedade mais adaptável ao local. 
Trabalhos de pesquisa das mais diversas variedades de cana-deaçúcar, em várias regiões produtora no Brasil e no mundo, têm apresentado um aumento da produtividade de colmo e açúcar devido ao emprego da irrigação, seja plena ou por salvamento. No Brasil, foram realizados alguns estudos com o objetivo de avaliar o regime irrigado da cultura da cana-de-açúcar em diferentes ambientes produtivos (DALRI e CRUZ, 2002; DANTAS NETO et al., 2006; DALRI et al., 2008; FARIAS et al., 2008; GAVA et al., 2008; e CARVALHO et al., 2015).

No município de Capim, PB, Dantas Neto et al. (2006) pesquisaram sobre o comportamento da variedade de cana-de-açúcar SP79-1011, durante o ciclo da primeira soca (correspondendo a segunda folha), sob o manejo de diferentes lâminas de irrigação e níveis de adubação de cobertura. As lâminas aplicadas nos tratamentos corresponderam a 807, 986, 1164 e $1343 \mathrm{~mm}$, utilizando níveis de adubação por cobertura de 85 e $305 \mathrm{~kg} \cdot \mathrm{ha}^{-1}$ de $\mathrm{N}$ e $\mathrm{K}_{2} \mathrm{O}$ na proporção de 1:0,94. Os autores analisaram: o crescimento, a qualidade e o rendimento da planta; e verificaram que as irrigações aplicadas na fase inicial e no seu início máximo de desenvolvimento da primeira soca, tiveram uma influência direta no comportamento dos mesmos. Os parâmetros de crescimento, tiveram um comportamento linear positivo, e a sacarose em um comportamento quadrático, em relação a lâmina de irrigação. Sendo que as doses de adubação produziram efeitos maiores nos parâmetros analisados que a lâmina de irrigação aplicada.

Nas mesmas condições edafoclimáticas, Farias et al. (2008) avaliaram o desenvolvimento morfofisiológico (parte aérea e raiz) da cana-de-açúcar, da variedade SP79-1011, em regime irrigado e sequeiro. Os autores verificaram que, a cana sob o regime de irrigado, apresentou uma taxa máxima de acúmulo de fitomassa de 0,7169 g.dia ${ }^{-1}$ e 0,6974 g.dia ${ }^{-1}$ sobre o regime de sequeiro. O índice máximo de área foliar foi de 6,82 em 152 DAP (dias após o plantio) na cana irrigada e de 6,80 em 157 DAP sob sequeiro. Eles ressaltam que o sistema de irrigação pode ser dimensionado tomando-se a profundidade radicular de $60 \mathrm{~cm}$ como base, pois no final do período de cultivo, foram identificados $90 \%$ da fitomassa de raízes concentradas nessa profundidade.

Ensaios de campo, analisando a cana-planta, foram conduzidos por Oliveira et al. (2011), no município de Carpina, PE, no período de julho de 2006 a novembro de 2007, para verificar os efeitos de diferentes regimes hídricos no solo 
(sequeiro e irrigação plena), sobre atributos tecnológicos, a eficiência de uso da água, produção de colmo e açúcar, em 11 variedades de cana, com maturação precoce, média e tardia. As variedades analisadas foram: SP79-1011, RB813804, RB863129, RB872552, RB943365, RB72454, RB763710, SP78-4764, SP81-3250, RB867515 e RB92579. Como resultados, os autores observaram que não houve diferença nos atributos tecnológicos entre os regimes de irrigação plena e de sequeiro, com exceção das variedades RB72454, RB763710 e RB943365. A cana sob irrigação apresentou maior eficiência de uso da água, chegando a uma produção média de $70,2 \mathrm{~kg} \mathrm{ha}^{-1} \mathrm{~mm}^{-1}$ de colmos a mais que a cana sob regime de sequeiro. $\mathrm{O}$ açúcar teve um acréscimo na produção superior a 200\% nas variedades RB92579 e RB943365.

O rendimento de açúcar e álcool da terceira folha da cana-deaçúcar foi avaliado por Carvalho et al. (2009), nos Tabuleiros Costeiros da Paraíba, submetida à irrigação $(0,50,100$ ou $150 \%$ da lâmina utilizada na fazenda) sob dois regimes de adubação de cobertura (72 e $\left.276 \mathrm{~kg} \cdot \mathrm{ha}^{-1}\right)$, tomando como referencial a variedade SP 791011. A precipitação efetiva durante o ciclo da cultura foi de $775 \mathrm{~mm}$ e as lâminas aplicadas com a irrigação foram de 0, 152, 290 e 393 mm. As aplicações de água foram feitas por um sistema de irrigação tipo pivô central rebocável, em turnos de 12 dias, e a evapotranspiração foi calculada com base no tanque classe "A" menos a precipitação efetiva. A interação fatores adubação de cobertura $\times$ irrigação não alterou significativamente o rendimento da terceira folha de cana. O aumento da lâmina de irrigação resultou em acréscimos na produção de colmos, no rendimento bruto de açúcar e no rendimento bruto de álcool. Valor máximo de lâmina aplicada foi de $1.168 \mathrm{~mm}$.

Em ensaios conduzidos por Dalri et al. (2008), em Botucatu, SP, avaliando a frequência de irrigação por gotejamento subsuperficial na produção e qualidade tecnológica da cana-de-açúcar, variedade RB72454, no seu primeiro ciclo, notaram que a irrigação por gotejamento não alterou a qualidade da cana-de-açúcar e não houve diferenças estatísticas significativas entre as diferentes frequências de irrigação. A produção de colmos foi de 202,2 t.ha ${ }^{-1}$, 297,9 t.ha ${ }^{-1}$, 320,6 t.ha' ${ }^{-1}$ e 282,8 t.ha ${ }^{-1}$, na testemunha e nos tratamentos L1, L2 e L3, respectivamente. Comparado com a testemunha, o tratamento L2 se mostrou 58,5\% maior na produção de colmos. Os tratamentos foram definidos pela frequência da irrigação, sendo que o sistema de irrigação era acionado quando a evapotranspiração da cultura superasse $10 \mathrm{~mm}$ (L1), 20 mm (L2) e 30 mm (L3) mais um tratamento testemunha (sem irrigação). 
Nas condições edafoclimáticas do município de Jaú, SP, Gava et al. (2008) avaliaram o desempenho produtivo das variedades de cana-de-açúcar RB867515, RB855536 e SP80-3280. Todas sob regime irrigado por gotejamento subsuperficial e de sequeiro. Houve interação entre o manejo adotado e os genótipos avaliados. A irrigação por gotejamento, apresentou uma resposta significativa, com um incremento na sua produção, em média, de $24 \%$ em colmos e de $18 \%$ de açúcar. A cultivar que mais se destacou foi a RB867515 (ciclo de 11 meses), apresentou um rendimento de colmos de 141,0 t.ha ${ }^{-1}$ e de 18,7 t.ha ${ }^{-1}$ de açúcar, e com a aplicação de uma lâmina de irrigação de $400 \mathrm{~mm}$, houve um incremento de $24 \%$ em relação à testemunha sem irrigação.

Para as mesmas condições climáticas e de solo, Silva et al. (2009) avaliaram o potencial de produção e qualidade tecnológica do caldo de oito variedades de cana (IAC91-1099, IACSP93-3046, IACSP93-3060, PO88-62, RB855536, RB867515, SP83-2847 E SP85-1115) sob irrigação por gotejamento subsuperficial. As parcelas experimentais foram constituídas por cinco fileiras duplas, com oito metros de comprimento cada e espaças entre si de 1,8 m. Os ensaios tiveram duração de 336 dias (cana planta) e de 365 dias (cana soca), durante os quais foram aplicadas lâminas de irrigação de $400 \mathrm{~mm}$ (cana planta) e $320 \mathrm{~mm}$ (cana soca). Houve diferenças significativas em termos produtivos entre as variedades avaliadas. Destacaram-se as cultivares IAC91-1099, IACSP95-3060, RB855536, RB867515 e SP85-1115 com produtividades médias superiores a 114,2 t.ha ${ }^{-1}$. Em termos de açúcar total recuperável, a diferença foi obtida apenas na primeira colheita, com destaque para a cultivar SP85-1115, com média de 145,4 kg.ha-1 ${ }^{-1}$, respectivamente.

No Paquistão, durante os anos de 2004 e 2005, estudos sobre o crescimento, produtividade e qualidade tecnológica da cana-de-açúcar, cultivar HSF240, em resposta a aplicação de diferentes técnicas de plantio, métodos de irrigação, níveis de disponibilidade de água no solo e tipos de cobertura do solo foram conduzidos por Chattha (2007). Concluiu que as características agronômicas avaliadas foram significativamente afetadas pelos métodos de irrigação e níveis de disponibilidade de água no solo avaliados. As maiores produtividades de colmos (104,9 t.ha ${ }^{-1}$ e 105,8 t.ha ${ }^{-}$ ${ }^{1}$ ) foram obtidas com o método alternativo de irrigação (skip irrigation - sulcos entre as fileiras de plantas) e aplicando-se $3.000 \mathrm{~mm} / \mathrm{ha}$, durante todo o ciclo da cultura, economizando $25 \%$ de água em relação ao método tradicional de irrigação. As 
características tecnológicas (brix, pureza, fibra, açúcares totais e açúcares recuperáveis) não foram afetadas pelos métodos e manejo de irrigação.

Em Alagoas, Teodoro et al. (2009) avaliaram características agroindustriais de nove variedades de cana-de-açúcar irrigadas de suplementação por gotejamento, em um ciclo de 12 meses. As variedades analisadas foram: RB92579, RB863129, RB931003, RB93509, RB72454, RB867515, RB951541, RB971755 e RB98710. Os resultados para rendimento de colmos mostraram que a cultivar RB92579 produziu 185 t.ha $^{-1}$, com $141 \mathrm{~kg}$ de açúcares totais recuperáveis por hectare. As variedades RB92579, RB93509, RB951541, RB931003 RB98710 e RB867515 foram as que apresentaram o maior potencial de produtividade satisfatório para cultivos irrigado por gotejamento. Dessa forma, os autores ressaltam que o uso da irrigação durante a estação seca e verânicos ameniza os efeitos da má distribuição de chuva na região, e que a adoção desse sistema pode aumentar significativamente a produtividade e a longevidade da cultura, juntamente com outros fatores de produção (adubação, controle de pragas e doenças, potencial genético das cultivares).

No caso específico da região Meio-Norte, estudos conduzidos por Andrade Júnior et al. (2012), analisando aplicação da fertirrigação em sistema de irrigação por gotejamento subsuperficial, evidenciaram a viabilidade técnica desse sistema em cana-de-açúcar, nas condições de solo e clima de União, PI. Os resultados mostraram que em uma aplicação de uma lâmina de $1.154 \mathrm{~mm}$ de água, com 114,2 kg.ha ${ }^{-1}$ de $\mathrm{N}$ e de 60,1 kg.ha ${ }^{-1}$ de $\mathrm{K}_{2} \mathrm{O}$, conseguiu a produção em máximo rendimento de colmos (207,4 Mg.ha $\left.{ }^{-1}\right)$. E com $90 \mathrm{~kg} \cdot \mathrm{ha}^{-1}$ de $\mathrm{N}$ e de $60 \mathrm{~kg} \cdot \mathrm{ha}^{-1}$ de $\mathrm{K}_{2} \mathrm{O}$, associado ao mesmo valor de lâmina, se produziu o valor máximo de açúcar e álcool (25,3 Mg.ha $\left.{ }^{1}\right)$ e de álcool $\left(20,0 \mathrm{~m}^{3} \cdot \mathrm{ha}^{-1}\right)$.

Os estudos, de uma forma geral, têm demonstrado resposta positiva, em termos de produção de açúcar e álcool, de alguns genótipos de cana-deaçúcar, os quais, em sua totalidade, oriundos de programas de melhoramento voltados à obtenção de variedades destinadas ao cultivo de sequeiro. É importante salientar que devido às variações de solo, clima e genótipos avaliados não existe uma indicação única de resposta para os níveis de disponibilidade de água no solo a serem mantidos visando à obtenção de produtividades elevadas de açúcar e álcool, devendo ser conduzidos ensaios nos diferentes ambientes de produção no Brasil. 


\subsection{Geoprocessamento}

Geoprocessamento é a área de conhecimento que utiliza técnicas matemáticas e computacionais para o tratamento da informação geográfica e que vem influenciando de maneira crescente as áreas de Cartografia, Análise de Recursos Naturais, Transportes, Comunicações, Energia e Planejamento Urbano e Regional (CÂMARA; DAVIS, 2001). Representa, ainda, um conjunto de tecnologias capazes de coletar e tratar informações georreferenciadas, que permitam o desenvolvimento constante de novas aplicações (GOMES, 2015). O Ministério do Meio Ambiente (MMA) utiliza essa tecnologia nos estudos técnicos que desenvolve, procurando estar sempre atualizado em relação aos avanços científicos nas áreas de obtenção, processamento e difusão de dados espaciais (MMA, 2015). Assim como o MMA muitas outras instituições públicas e privadas utilizam a técnica, desenvolvendo trabalhos nas mais diversas áreas, servindo como parâmetro tomadas de decisões. Segundo Antunes (2015) o geoprocessamento é uma ferramenta imprescindível para o Brasil em função da dinâmica transformação do seu território e da consequente necessidade de seu monitoramento.

Como é uma área cuja a tecnologia é bem abrangente, o geoprocessamento, engloba a informações técnicas de ferramentas como: Sistema de Informação Geográfica (SIG), Sensoriamento Remoto (SR), Sistema de Posicionamento Global (GPS). As ferramentas chamadas de SIG (ou GIS, Geographic Information System, em inglês), permitem realizar análises complexas, ao integrar dados de diversas fontes e ao criar bancos de dados georreferenciados, tornando possível automatizar a produção de documentos cartográficos (CÂMARA; DAVIS, 2001). O SR é um processo de medição e obtenção de dados sobre um objeto ou fenômeno, ou mesmo alguma propriedade deste, através de sensores que não se encontram em contato físico com o objeto ou fenômeno estudado (PNC DAS CIDADES, 2008). O GPS é uma ferramenta de coleta de dados geográficos, utilizado para fins de navegação ou para uso no SIG, permitindo que o usuário, em qualquer ponto da superfície terrestre, ou próximo a ela, tenha sempre a disposição, no mínimo 4 satélites para serem rastreados, permitindo navegação em tempo real, sob quaisquer condições meteorológicas, indicando sua posição geográfica no globo terrestre (FIGUEIRÊDO, 2005). 
De acordo com CAMARA et al. (1996) o SIG integra numa única base de dados informações espaciais provenientes de dados cartográficos, dados de censo e cadastro urbano e rural, imagens de satélite, redes e modelos numéricos de terreno, ou seja, é uma ferramenta que agrega mecanismos que combina várias informações, por meio de algoritmos de manipulação e análise, para consultar, recuperar e visualizar o conteúdo da base de dados e gerar mapas. Logo, os softwares desenvolvidos como SIG, integram informações vinda de SR e GPS. Camara; Queiroz (2001) afirmam que há pelo menos três grandes maneiras de utilizar um SIG: como ferramenta para produção de mapas, como suporte para análise espacial de fenômenos, e como um banco de dados geográficos, com funções de armazenamento e recuperação de informação espacial.

Atualmente existem diversos softwares desenvolvidos como SIG, de licença livre ou comercial, cada uma com suas especificidades e limitações, aplicados as mais diversas áreas. No site do MMA, pode ser encontrado uma lista de SIG's livres destinadas ao usuário das ferramentas, contendo análise de cada um dos softwares identificando suas principais funcionalidades. O MMA (2015) ressalta que as análises feitas no site se restringiram às funcionalidades disponíveis nas interfaces padrão, sem a verificação completa das outras bibliotecas disponíveis em cada programa.

Algumas análises podem exigir o uso de vários SIG's, por causa de suas limitações que cada um apresenta. Entre os SIG's mais difundido pode-se citar: Spring, desenvolvido pelo o Instituto Nacional de Pesquisas Espaciais (INPE); o ArcGIS, um pacote pertencente a Environmental Systems Research Institute (ESRI); IDRISI, elaborado desenvolvido na Clark University Graduate School of Geography; e o QUANTUM GIS®, elaborado por Open Source Geospatial Foundation (OSGeo).

O SIG Quantum Gis® é um software de código aberto licenciado segundo a Licença Pública Geral GNU, que funciona em ambientes de Linux, Unix, Mac OSX, Windows e Android e suporta inúmeros formatos de vetores, rasters e bases de dados e funcionalidades, com uma interface gráfica amigável de fácil uso, escrito em C++ e Python e baseado nas bibliotecas Qt4 (MANGHI, G.; CAVALLINI, P. e NEVES, 2011). O projeto que deu origem ao Quantum GIS teve início no ano de 2002 e tinha como objetivo criar um visualizador gratuito para a base 
de dados PostGIS que funcionasse em sistemas operacionais livres (GNU/Linux) (ALMEIDA, 2016).

Nanni et al. (2016) explicam que na plataforma do Quantum Gis® se consegue sobrepor dados vetoriais e raster em diferentes formatos e projeções sem conversão para um formato interno comum. Os mesmo autores ressaltam que isso é possível porque o Quantum Gis® suporta os formatos do tipo: tabelas PostgreSQL espacialmente habilitadas usando PostGIS; formatos vetoriais suportados pela biblioteca OGR instalada, incluindo arquivos do tipo shapefile, MapInfo, SDTS, GML; formatos Raster e de imageamento suportados pela biblioteca GDAL (Geospatial Data Abstraction Library) instalada, como GeoTiff, Erdas Img., ArcInfo Ascii Grid, JPEG, PNG; bases de dados SpatiaLite; raster do GRASS e dados vetoriais a partir de banco de dados GRASS; dados espaciais OCG hospedados on-line em servidores do tipo Web Map Service (WMS) ou Web Feature Service (WFS); e dados OpenStreetMap.

O Quantum Gis® recebe constantes contribuições de voluntários e de profissionais da área de geoprocessamento que buscam aprimorar o software identificando e divulgando suas falhas, produzindo tutoriais, traduzindo manuais, gerando novas ferramentas e melhorando as ferramentas já existentes (ALMEIDA, 2016). Na internet pode-se encontrar fóruns, blogs e perfis de redes sociais destinadas apenas aos usuários desse SIG. Neles pode-se tirar dúvidas, promover debates, trocar experiências, organizar e divulgar eventos na área, promovendo a divulgação do Quantum Gis® nas mais diversas línguas, incluindo o português.

Num país de dimensão continental como o Brasil, com uma grande carência de informações adequadas para a tomada de decisões sobre os problemas urbanos, rurais e ambientais, o Geoprocessamento apresenta um enorme potencial, principalmente se baseado em tecnologias de custo relativamente baixo, em que o conhecimento seja adquirido localmente (CAMARA; DAVIS; MONTEIRO, 2001). Pelos motivos relatados anteriormente, Pereira et al. (2011) relatam que o uso do geoprocessamento como ferramenta para elaboração de zoneamentos no Brasil, podem ter sido iniciadas na década de 1970, com o objetivo de fazer uma análise sobre impactos ambientas, e ganharam ênfase por meio da Lei $\mathrm{n}^{\circ} 6.938$, em 1981, que estabelece os objetivos e as normas da Política Nacional de Meio Ambiente - PNMA, fazendo referência ao zoneamento ambiental como instrumento de política para tomadas 
de decisões. Dessa forma foram elaborados vários tipos de zoneamentos nas mais diversas áreas.

Como exemplo pode-se citar o trabalho de Irmão e Maciel (2015), que elaboraram um zoneamento econômico ambiental, para Rio Branco, AC, com o objetivo de usá-lo como instrumento estratégico fundamentado na Sustentabilidade que contribuirá, significativamente, para o planejamento e reorientação das políticas públicas, dando suporte à gestão territorial e subsidiando a tomada de decisões do setor privado e da sociedade em geral. Utilizaram as ferramentas de geoprocessamento para o levantamento de diversas informações, dentre elas: os aspectos do solo (diagnóstico), dinâmica do desmatamento, tipologias florestais, aptidão à mecanização e outros.

O geoprocessamento é uma técnica que devido à sua variabilidade na aplicação e seu baixo custo, vem se difundido bem rápido, se popularizando, com resultados satisfatórios e relevantes integrando variáveis ambientais, antrópicas, climáticas, entre outras. Dessa forma, tornar uma ferramenta extremamente necessária para planejamento e tomadas de decisões.

\subsection{Zoneamento Agrícola}

O zoneamento agrícola é uma ferramenta com o objetivo de identificar áreas homogêneas e classificá-las de acordo com critérios pré-estabelecidos que levam em consideração características de solo, clima e planta. Assim, o zoneamento agrícola é fundamentado na potencialidade climática e edáfica de uma região, quanto os riscos associados são de alta relevância (CIIAGRO, 2015).

Segundo Cecílio et al. (2003), o zoneamento agrícola tem uma fundamental importância no momento em que se irá organizar trabalhos na área, tomar decisões ou dá suporte ao planejamento da agricultura. Eles justificam essa importância pelo fato do zoneamento tomar como base em aferições de fatores que caracterizam as aptidões agrícolas, distribuídas na região em estudo. Os autores recomendam o uso de elementos climáticos como: a precipitação, insolação, temperatura do ar e índices obtidos do balanço hídrico do solo, na elaboração do zoneamento agrícola. Além disso, deve-se conhecer as características fisiológicas da cultura e dados sócio-econômicos. Assim, através de espacialização utilizando um Sistema de Informação Geográfica 
(SIG), define as regiões, em estudo, que possuem aptidão para o cultivo da cultura, em um certo tipo de solo e a melhor época de plantio.

O Ministério da Agricultura, Pecuária e Abastecimento (MAPA) vem adotando o zoneamento de risco climático como ferramenta orientadora da política agrícola para o Governo Federal, sendo usado pela primeira vez em 1996 para a cultura do trigo, mas que, atualmente, são 40 culturas com 15 ciclo anual, em 24 Unidades da Federação, publicado e revisado anualmente por meio de portarias (MAPA, 2010).

De acordo com Marin (2015), o zoneamento de risco climático da cana-de-açúcar ainda não possui portarias publicadas, mas o MAPA vem discutindo com outros Ministérios e organizações da sociedade civil, com bases técnicas estabelecidas e coordenadas pela Empresa Brasileira de Pesquisa Agropecuária (Embrapa), em parceria com algumas instituições e universidades.

$\mathrm{Na}$ literatura encontramos outros tipos de zoneamentos da canade-açúcar, desenvolvido para diversas regiões do país e outros em elaboração ou revisão por macros projetos organizados pela Embrapa, universidades e instituições civis e públicas, visando regionalização, e sustentabilidade da cultura.

\subsubsection{Aptidão climática}

As atividades agrícolas sofrem influência direta dos fatores climáticos, portanto estudos sobre as condições climáticas são importantes para conhecer como as mesmas influenciam o desenvolvimento das culturas. Assim, é de suma importância fazer um levantamento climatológico do ambiente em que se deseja implantar uma determinada cultura, dessa maneira, pode-se fazer planejamento sobre o manejo mais adequado ou até mesmo a substituição da cultura por outra que melhor se adapte às condições climáticas locais, obtendo uma maior produção.

Segundo Rossin; Tommaselli (2010) ressaltam a importância de se relacionar fatores climáticos à produção agrícola, pois acreditam que a maior parte de toda a produção é prejudicada por eventos climáticos atípicos da região e por não haver um planejamento agrícola adequado. Almeida, Calijuri e Pinto (2013) afirmam que a temperatura do ar influencia diretamente o nível de sacarose da cana, além de inibir a sua brotação, em caso de temperatura ar muito baixas, e prejudicar o crescimento e desenvolvimento da planta. Dessa forma, Marin (2015) recomenda que a cana-de-açúcar 
deve ser cultivada em locais com condições climáticas específicas, dependendo do produto que se deseja obter: açúcar de usina, aguardente ou forragem.

Segundo Varejão-Silva; Barros (2001), a cana-de-açúcar sofre influência direta do clima, ela exige um período vegetativo que se mantenha em condições consideradas ótimas de temperatura e disponibilidade hídrica, para o seu desenvolvimento. Os autores realizaram zoneamento de aptidão climática da cana-deaçúcar, para Pernambuco, utilizando como indicadores as temperaturas médias mensais (Tm) e índice de umidade anual, divididas em quatro classes (tabela 1).

Tabela 1 - Valores de referência considerados para diversos parâmetros na definição das classes climáticas

\begin{tabular}{lclc}
\hline \multicolumn{2}{c}{ Índice de umidade anual } & \multicolumn{2}{c}{ Temperatura média anual } \\
\hline Inapta & $\mathrm{Iu} \leq-10$ & Inapta & $\mathrm{Tm}<18^{\circ} \mathrm{C}$ \\
Aptidão restrita & $-10<\mathrm{Iu}<0$ & Restrita & $18^{\circ} \mathrm{C}<\mathrm{Tm}<19^{\circ} \mathrm{C}$ \\
Aptidão moderada seca & $0<\mathrm{Iu}<10$ & Moderada seca & $19^{\circ} \mathrm{C}<\mathrm{Tm}<21^{\circ} \mathrm{C}$ \\
Apta & $10<\mathrm{Iu}<60$ & Apta & $\mathrm{Tm}>21^{\circ} \mathrm{C}$ \\
Moderada úmida & $\mathrm{Iu} \geq 60$ & & \\
\hline \multicolumn{2}{l}{ Fonte: Varejão-Silva; Barros $(2001)$} & &
\end{tabular}

Eles definiram essas classes como períodos de características climáticas bem distintas de acordo com a sua influência no desenvolvimento da cultura. A classe definida como "apta" indica áreas sem limitações climáticas à cultura; a de "aptidão moderada", indica áreas com pequena deficiência hídrica necessitando de uma irrigação suplementar; a de "aptidão moderada úmida" são áreas com período chuvoso longo, que prejudica a formação da sacarose; a de "aptidão restrita" são áreas com certa deficiência hídrica que exige uma irrigação de salvamento; e de "inaptidão climática" são áreas que o cultivo necessita de uma irrigação plena.

Manzatto et al. (2009), no desenvolvimento do zoneamento agroecológico da cana-de-açúcar para o Brasil, utilizaram parâmetros climáticos de temperatura média do ar anual (Ta), deficiência hídrica anual (Da) e índice de satisfação da necessidade de água (ISNA), para caracterizar áreas com aptidões climáticas para o cultivo da cana-de-açúcar. Classificaram como baixo risco para o cultivo sem irrigação a região que apresentou $\mathrm{Da}<200 \mathrm{~mm}$ e a Ta $>19^{\circ} \mathrm{C}$, além de índice de satisfação da necessidade de água (ISNA) > 0,6 e risco de geada $<20 \%$. Para o cultivo com irrigação de salvação, consideraram a deficiência hídrica anual (Da) $>200 \mathrm{~mm}$ e Da $<400 \mathrm{~mm}$, para delimitar as áreas com aptidão sob essa condição. 
Collicchio (2008), no zoneamento edafoclimático e ambiental para cana-de-açúcar no estado de Tocantins, utilizou os parâmetros climáticos definidos por Camargo et al. (1977), que dividiram em seis classes denominadas de: A - apta com condições térmicas e hídricas satisfatórias $\left(\mathrm{Ta}>20^{\circ} \mathrm{C}\right.$ e $\left.\mathrm{Da}<200 \mathrm{~mm}\right)$; B - marginal com certa restrição térmica $\left(18^{\circ} \mathrm{C}<\mathrm{Ta}<20^{\circ} \mathrm{C}\right.$; Ta $>14^{\circ} \mathrm{C}$; $\left.\mathrm{Da}<200 \mathrm{~mm}\right)$; $\mathrm{C}-$ marginal, apresenta restrição hídrica, justificado com a irrigação suplementar (Ta > $18^{\circ} \mathrm{C}$ e $200 \mathrm{~mm}<\mathrm{Da}<400 \mathrm{~mm}$ ); D - marginal a inapta para a produção, por não apresentar estação de repouso por frio ou por seca $\left(\mathrm{Ta}>24^{\circ} \mathrm{C}\right.$ e $\left.\mathrm{Da}=0 \mathrm{~mm}\right)$; E - inapta para a produção de açúcar por deficiência hídrica acentuada ( $\mathrm{Da}>400 \mathrm{~mm}$ ) e F - inapta por carência térmica ou pela ocorrência de geadas excessivas $\left(\mathrm{Ta}<18^{\circ} \mathrm{C}\right.$ e ou $\mathrm{Ta}<$ $\left.14^{\circ} \mathrm{C}\right)$.

No anuário desenvolvido por Waldheim et al. (2006) foram consideradas áreas aptas aquelas com $\mathrm{Ta}>21^{\circ} \mathrm{C}$; restrita com $\mathrm{Ta}<19^{\circ} \mathrm{C}$ e $\mathrm{Da}>140$ $\mathrm{mm}$; e inapta com $\mathrm{Ta}<18^{\circ} \mathrm{C}, \mathrm{Da}=0 \mathrm{~mm}$ e excedente hídrico anual (Ea) $>800 \mathrm{~mm}$. Com base nesses critérios, indicaram os municípios de Paulistana e Picos no estado do Piauí, como restritos para o cultivo de cana-de-açúcar.

Marin (2015), define as condições climáticas exigida pela canade-açúcar. Entre as definições ele cita a exigência térmica da cultura, que encontra-se entre $21^{\circ} \mathrm{C}$ a $30^{\circ} \mathrm{C}$ de temperatura média do ar, considerada ideal para um ótimo crescimento e desenvolvimento da cultura. Abaixo de $20^{\circ} \mathrm{C}$, o autor afirma que a produção é prejudicada.

Portanto, constata-se, que de acordo com a região onde o zoneamento foi executado, uma grande diversidade de parâmetros e indicadores climáticos passíveis de serem utilizados para a delimitação e indicação de áreas climaticamente aptas ao cultivo de cana-de-açúcar, notadamente os relacionados à temperatura média anual e deficiência hídrica anual.

\subsubsection{Aptidão edáfica}

Além das condições climáticas ótimas, a cultura necessita de um determinado tipo de solo para um bom desenvolvimento, portanto, a aptidão edáfica deve ser incluída dentro do zoneamento agrícola. Dessa forma, o solo deve ser 
classificado considerando suas características físicas e fisiográficas, sob um determinado tipo de manejo para a cultura (MANZATTO et al., 2009).

Brunini et al. (2010) caracterizaram as áreas com aptidão agrícola boa como aquelas que possuem solos com alta fertilidade natural, onde não há pedregosidade e tenha uma profundidade favorável; a aptidão agrícola média considera o caráter distrófico e/ou a profundidade desfavorável e a aptidão restrita considera duas ou mais condições desfavoráveis. Definiram ainda os solos Argissolos, Cambissolos, Latossolos, Luvissolos, Neossolos Quartzarênicos e Nitossolos como sendo de condição favorável de profundidade do solo, sem restrição física a livre penetração radicular; e solos Neossolos Litólicos e Plintossolos com condição desfavorável de profundidade de solo que limita o crescimento radicular. Esses parâmetros foram usados no trabalho de zoneamento da cana-de-açúcar de Collicchio (2008), aplicado a Tocantins.

Aptidão agrícola dos solos é dividida em três classes principais: boa, regular, restrita e inapta. As classes principais são subdivididas em seis grupos (1, $2,3,4,5$, e 6) e esses grupos são enquadrados de acordo com os níveis de manejo adotados denominados de A, B e C. De acordo com o nível de manejo (A, B e C), os subgrupos que indicam melhor aptidão são as de 1 a 3 , área adequadas a lavouras. $\mathrm{O}$ subgrupo 4 indica áreas representadas por pastagem plantada, e o subgrupo 5 a silvicultura e/ou pastagem natural. O subgrupo 6 indica áreas que não pode haver nenhum manejo de produção agrícola, pois são área de preservação da flora e da fauna. Quando a classificação por manejo, o manejo A tem como base práticas agrícolas de baixo nível tecnológico, que são aquelas que exigem um trabalho mais braçal, que podem utilizar tração animal com implementos agrícolas mais simplistas. O manejo B tem como base práticas agrícolas de nível tecnológico médio, essas práticas agrícolas estão condicionadas diretamente à tração animal. $\mathrm{O}$ manejo $\mathrm{C}$ tem como base práticas agrícolas com alto nível tecnológico, com a presença da mecanização nas diversas fases da implantação e manutenção da cultura (RAMALHO FILHO; BEEK 1995; MANZATTO et al., 2009; CARVALHO et al., 2009).

O fator mecanização, mencionado anteriormente como um dos atributos a ser observado na aptidão edáfica, é de suma importância, para a produção agrícola atual, pois as colheitadeiras disponíveis no mercado são adaptadas para declividade de até $12 \%$. Nas últimas décadas, a mecanização da cana-de-açúcar é aplicada à colheita e ao plantio. Devido a alguns fatores como: artigo 40 do Código 
Florestal determinando a instituição de uma política nacional para a colheita por meio da queima; a antecipação da proibição dessa prática pelo estado de São Paulo, com planos diferenciados para áreas mecanizáveis de forma gradual; a Norma Regulamentadora NR-31 que estabelece critérios mais rigorosos em relação a mão-deobra; e a redução de custo no setor sucroalcooleiro; a mecanização do sistema de produção agrícola cresceu consideravelmente no país.

Brunini (2007), estabeleceu a mecanização como um dos critérios na elaboração do zoneamento das culturas bioenergética, incluindo a cana-deaçúcar, para o estado de São Paulo. As classes de capacidade de usos de solos, foram estabelecidas associando com a mecanização, a fertilidade do solo e o sistema de manejo.

Os benefícios da mecanização foram observados por Rosetto (2015). O autor afirma que o manejo mecanizado da cultura, proporciona uma maior proteção ao solo contra a erosão, redução da poluição ambiental e diminuição de impurezas minerais.

Dessa forma, Manzatto et al. (2009), Collicchio (2008) e o Ministério da Agricultura e Abastecimento (MAPA) (BRASILb, 2015) adotaram declividade abaixo de $12 \%$ para a região considerada apta para a mecanização. Para o cultivo da cana-de-açúcar, o mesmo critério foi adotado para esse zoneamento, utilizando imagens SRTM (Shuttle Radar Topography Mission), para extração de dados topográficos relativos à altimetria por meio dos modelos digitais de elevação (MDE), para o cálculo de declividade. Essa metodologia, também, foi utilizada por Manzatto et al. (2009) e Collicchio (2008).

\subsubsection{Balanço hídrico da cultura}

A irrigação, como uma prática de complementação ou de salvação, é essencial no Nordeste brasileiro, onde as chuvas são mal distribuídas e o recurso água é escasso. Assim, o uso racional desse recurso considerando técnicas que venham a auxiliar a sustentabilidade na produção agrícola e ainda ter um produto em grande quantidade e qualidade com custos competitivos é o desafio imposto à agricultura atual. 
O excesso de irrigação agrava o problema de escassez de água, e o manejo adequado do sistema de irrigação se faz necessário para economia no uso da água nessa atividade (PEREIRA et al, 2009). Logo, para um manejo racional da irrigação, visando a redução do desperdício e a otimização do consumo da água pela cultura, é necessário conhecer quando e quanto devo irrigar, com base no ciclo vegetativo da cultura. A resposta a essas questões se dá com o conhecimento da quantidade de água que há no solo, que se obtêm por meio do balanço hídrico.

Pereira, Angelucci e Sentelhas (2002) definiram o balanço hídrico como a contabilização de água no solo, ou seja, a quantidade de água que entra e saí do solo, em um volume vegetado, considerando o princípio de conservação de massa. Diversas ferramentas são utilizadas para a determinação ou estimativa da quantidade de água no solo, uma delas é o balanço hídrico da cultura.

O balanço hídrico da cultura elaborado por Thornthwaite e Mather (1995), é o mais difundido no meio científico, utilizando como variáveis de entrada no modelo, a precipitação, a temperatura média do ar, a latitude do local onde foi coletado os dados meteorológicos e a Capacidade de Água Disponível (CAD) no solo. Como resultado do balanço hídrico da cultura têm-se a evapotranspiração potencial, evapotranspiração real, deficiência hídrica, excedente hídrico, numa escala diária. Pereira, Villa Nova e Sediyama (1997), ressaltam a simplicidade do método para a aplicação no manejo da irrigação, que pode ser utilizado sob as mais diversas condições edafoclimáticas.

Silva et al. (2013) utilizam o balanço hídrico da cultura para fazer análise do zoneamento agrícola em cenários futuros, com alterações climáticas apresentado pelo Painel Intergovernamental sobre Mudanças Climáticas (IPCC), aplicado à cana-de-açúcar, avaliando seus possíveis impactos para tomada de decisões na região Nordeste.

Collicchio (2008) e Araújo Filho et al. (2000), desenvolveram zoneamentos para a cana-de-açúcar utilizando o balanço hídrico de Thornthwaite e Mather (1955) como ferramenta para indicação de locais onde existem melhores condições climáticas e hídricas exigidas pela cultura, para o Tocantins e Pernambuco, respectivamente. Por meio dessa mesma ferramenta foi elaborado o zoneamento de aptidão climática para o cultivo da cana-de-açúcar, em Minas Gerais, por Almeida, Calijuri e Pinto (2013). Eles identificaram uma grande área do estado restrita ao cultivo 
da cultura. Manzatto et al. (2009) utilizaram, também, o balanço hídrico de Thornthwaite e Mather (1955) no zoneamento agroecológico da cana (ZAE), como um dos parâmetros para identificação de áreas aptas a expansão da cultura no Brasil, em regime de sequeiro. O trabalho teve como objetivo fornecer bases técnicas para tomadas de decisões e elaboração de políticas públicas visando o ordenamento da expansão e a produção sustentável de cana no território brasileiro. 


\section{MATERIAL E MÉTODOS}

O estudo foi dividido nas seguintes etapas: elaboração do mapa de aptidão térmica para a cana-de-açúcar irrigada no estado do Piauí, elaboração de um mapa de declividade para definir áreas aptas ao manejo mecanizado, geração de mapas de lâminas de irrigação pelo sistema de gotejamento, e por último, o cruzamento de mapas de aptidão térmica, de declividade, e lâminas de irrigação, para todo o Estado.

\subsection{Caracterização da área de estudo}

\subsubsection{Local}

O estudo foi desenvolvido para o estado do Piauí, que possui uma área de 251.577,738 km² e 224 municípios (IBGE, 2010). Localizado na região nordeste do Brasil, em um quadrante correspondente às latitudes de 2०44'49” e

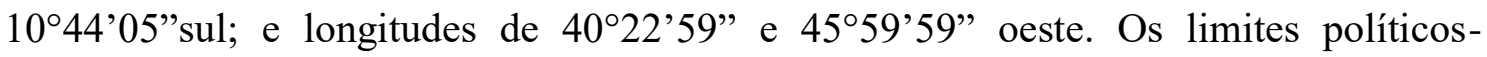
administrativo correspondem: ao norte o Oceano Atlântico, ao leste os estados do Ceará e Pernambuco, Bahia ao sul e sudeste, ao sudoeste Tocantins e oeste o Maranhão.

\subsubsection{Clima}

O Piauí encontra-se numa zona de transição entre três biomas brasileiros: o clima semiárido do Nordeste, clima úmido da Amazônia e o dos Cerrados. Com uma variação no espaço e tempo da precipitação pluviométrica o Estado mostra-se com dois regimes chuvosos: no sul do Estado chove de novembro a março; no centro e norte, a estação chuvosa tem início em dezembro, prolongando-se até maio (PIAUÍ, 2005). 
Seguindo a classificação de Köppen, o Estado possui clima quente e úmido com chuva de verão/outono e de verão (Aw’ e Aw, respectivamente), e clima semiárido (BSh). O clima Aw' ocorre no centro-norte do Estado, com o trimestre mais chuvoso em fevereiro-março-abril e agosto-setembro-outubro o mais seco, com precipitações pluviométricas variando de $1.000 \mathrm{~mm}$ a $1.800 \mathrm{~mm}$. O clima Aw ocorre no centro-sul e a sudoeste do Estado, com trimestre mais chuvoso em dezembro-janeirofevereiro e junho-julho-agosto o mais seco, com precipitações pluviométricas variando de $1.000 \mathrm{~mm}$ a $1.400 \mathrm{~mm}$. Na região leste e sudeste do Estado, predomina o clima BSh, ocorrendo os menores índices de pluviosidades variando de $400 \mathrm{~mm}$ a $1.000 \mathrm{~mm}$, com trimestre mais chuvoso nos meses de janeiro-fevereiro-março e julho-agosto-setembro são os meses mais secos (PIAUÍ, 2010).

De acordo com o Atlas Climatológico do Piauí, elaborado por Andrade Júnior et al. (2004), os meses de janeiro e fevereiro apresentam as temperaturas médias (Tm) entre 24 e $28{ }^{\circ} \mathrm{C}$, na maior parte do Estado, com exceção da região do extremo sudoeste, que apresenta valores entre 22 e $24{ }^{\circ} \mathrm{C}$. Os meses de março a maio, as temperaturas médias entre 24 e $36{ }^{\circ} \mathrm{C}$ ocorrem na região centro-sul do Estado, com valores entre 26 e $28{ }^{\circ} \mathrm{C}$ na região centro-oeste, predominando na maior parte do Estado. Em maio, junho e julho, enquanto a maior parte do Estado encontra-se com Tm entre 26 e $28^{\circ} \mathrm{C}$, os municípios de Pedro II e São Miguel do Tapuio, na região de fronteira com o Ceará, são encontrados os menores valores de Tm, com valores entre 22 e $24^{\circ} \mathrm{C}$.

A partir do mês de agosto, Andrade Júnior et al. (2004), observaram que a Tm começa a se elevar, na maior parte do Estado, com valores entre 26 a $28^{\circ} \mathrm{C}$, na maior parte do Estado. Em setembro, começa o período mais quente apresentando valores de Tm entre 28 e $30^{\circ} \mathrm{C}$, esse período segue até novembro. No mês de novembro as áreas com Tm acima de $28{ }^{\circ} \mathrm{C}$, começa a reduzir, se concentrado na região centro-norte. Em dezembro, a maiores $\operatorname{Tm}\left(28\right.$ a $\left.30^{\circ} \mathrm{C}\right)$ são encontradas na região norte do Estado. No restante do Estado observou a predominância de Tm entre 26 e 28 ${ }^{\circ} \mathrm{C}$, mas com menores Tm entre 22 e $24{ }^{\circ} \mathrm{C}$ ocorreram no extremo sudoeste.

\subsubsection{Solos}

Os solos do Piauí apresentam uma grande variabilidade de tipos de solo, e de acordo com IBGE - Embrapa (2001), os tipos presentes são: Argissolo 
vermelho-amarelo, Chernossolo argilúvico, Gleissolos sálicos, Latossolo Amarelo, Latossolo Vermelho Amarelo, Luvissolo Crômico, Neossolo Flúvico, Neossolo quartzarênico, Plintossolo Halico, Plintossolo pétrico e Vertisssolo eurânico. Segundo Mousinho (2005), os solos de maior abrangência do Estado (Argissolo, Neossolo, Latossolos e Luvissolo), em geral, apresentam de média a baixa fertilidade natural e grande variabilidade de retenção de água, apresentando potencialidade agrícola.

De acordo com dados divulgados pela Embrapa Solos, por meio de análise feita por Santos et al. (2011), na atualização da nova legenda, o sul e sudoeste do Estado encontra-se com predomínio de Latossolos Amarelos distróficos, seguido por grandes faixas de Neossolos Litólicos distróficos. Ao norte, fazendo fronteira com o Maranhão, encontra-se os solos Plintossolos Pétricos concrecionários e Plintossolos Háplicos distróficos em maior extensão. Na região central há uma grande variedade de tipos de solos predominando os Neossolos Litólicos distrófico e Latossolos VermelhoAmarelos distrófico.

\subsubsection{Fonte dos Dados}

Para a realização do trabalho, utilizou-se o banco de dados históricos de postos pluviométricos, disponibilizados pela Superintendência do Desenvolvimento do Nordeste (Sudene). O banco de dados foi composto por valores diários de 87 postos distribuídos no Piauí e em Estados vizinhos (Bahia, Ceará, Maranhão e Pernambuco), para uma melhor cobertura de toda área analisada, com um período histórico de registros diários de 15 anos (figura 1). A tabela com a descrição dos postos pluviométricos e sua localização geográfica pode ser visualizada no Apêndice 1.

Os arquivos vetoriais de municípios do estado do Piauí, no formato "shape", foram disponibilizados pelo IBGEa (2015), na escala 1:250.000, ano de 2010 e Datum SIRGAS 2000, para o cruzamento com os mapas temáticos gerados.

O software SIG utilizado para a confecção dos mapas temáticos, foi o Quantum GIS 2.8.2 ${ }^{\circledR}$ (QUANTUM GIS DEVELOPMENT TEAM, 2015). 


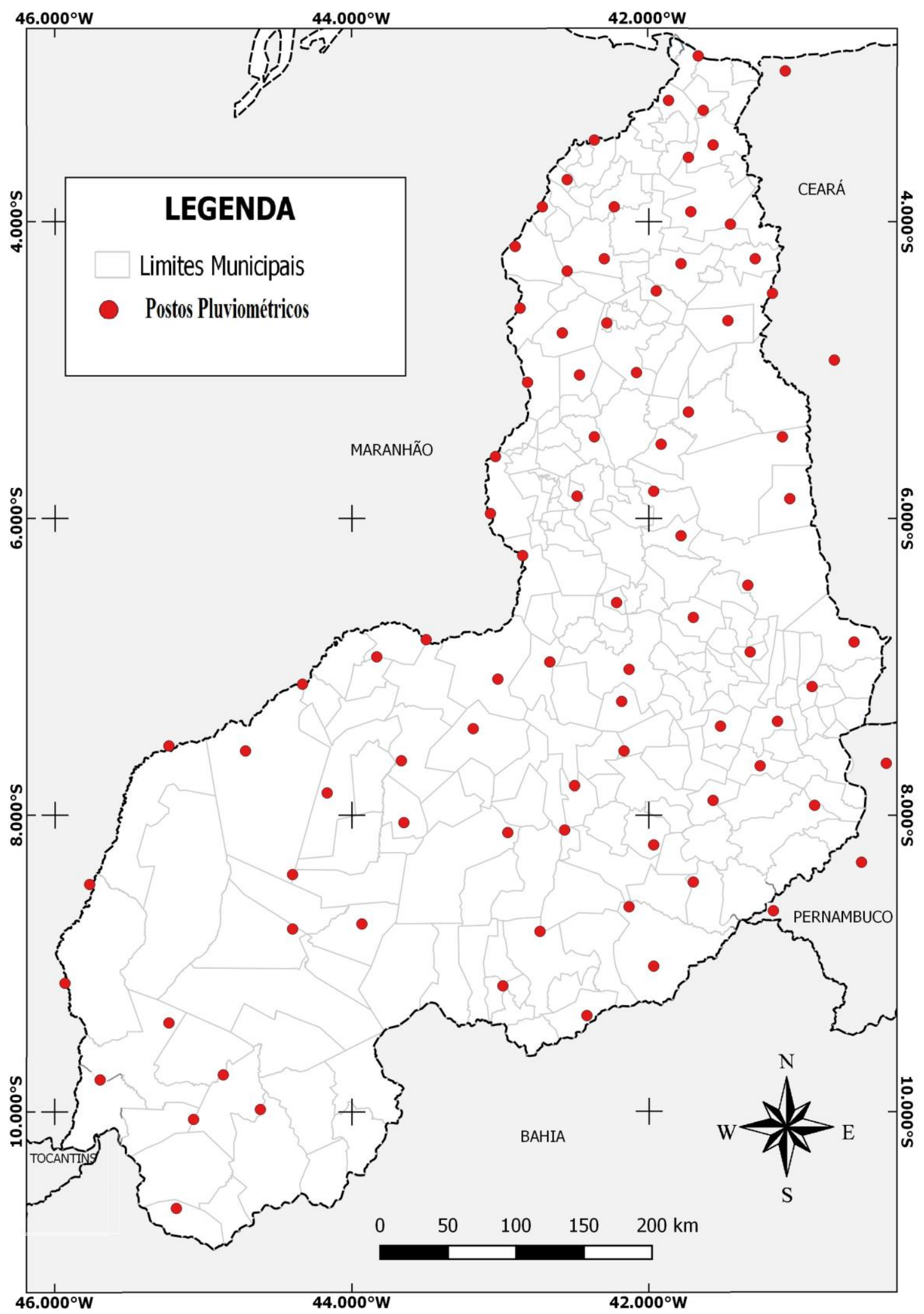

Figura 1 - Disposição geográfica dos postos pluviométricos utilizados no cálculo do balanço hídrico diário da cultura.

Fonte: Silva, C. O. da (2016). 


\subsection{Aptidão térmica para cana-de-açúcar irrigada}

O mapa de aptidão térmica foi elaborado com dados de temperatura média do ar em escala anual, para os 87 postos pluviométricos. Como não se disponibilizava de dados de temperatura média do ar medidos para todos os postos pluviométricos, utilizando a metodologia de Lima e Ribeiro (1998), que se baseia nos dados de latitude, longitude e altitude, foram estimadas as temperaturas médias mensais para cada posto, sendo esta metodologia empregada em vários outros trabalhos realizados na região tais como: Gomes, Andrade Júnior e Medeiros, 2005; Medeiros, 2007; Medeiros et al. 2013 e 2014.

Para esse estudo considerou valores de temperatura média do ar maior que $21^{\circ} \mathrm{C}$, considerando os parâmetros de exigência climática da cana-de-açúcar exposta por MAPA (Brasilb, 2015), para a elaboração do mapa.

A espacialização dos dados de temperatura média do ar, procedeu-se importando o arquivo com os 87 valores de temperatura média anual do ar, no formato *.csv, para o Quatum Gis®. Em seguida, interpolou os dados utilizando a ferramenta Vizinho mais próximo. Para a finalização do mapa temático, foi feito o recorte com a malha municipal do IBGE. O arquivo interpolado e recortado, foi rasterizado e depois vetorizado para unir os dois arquivos (temperatura média do ar e municípios). A união dos vetores foi realizada por meio de álgebra de mapas com ferramenta Interseção, resultando em um vetor com tabela de atributos de municípios e seus respectivos valores de temperatura média do ar interpolados.

\subsection{Aptidão para fins de mecanização}

O mapa de aptidão para fins de mecanização considerou o parâmetro da mecanização, pois a maioria dos produtores de cana-de-açúcar, normalmente, têm elevado nível tecnológico e adotam práticas agrícolas de forma intensiva. Desta forma, independentemente do potencial edáfico do solo para irrigação, as áreas com declividade superior a $12 \%$ serão descartadas do zoneamento, por representar áreas com dificuldade de mecanização nas diferentes etapas do processo de produção da cana-de-açúcar. Collicchio (2008), Manzatto et al. (2009) e o Ministério da 
Agricultura e Abastecimento (MAPA) (BRASILb, 2015) adotaram declividade abaixo de $12 \%$ para a região considerada apta para a mecanização e para o cultivo da cana-deaçúcar.

Para tanto, foi elaborado um mapa de declividade, a partir de dados de altimetria de mosaicos de imagens SRTM (Shuttle Radar Topograffic Mission) do banco de dados digital da U. S. Geological Survey - USGS, disponibilizado pelo projeto TOPODATA do INPE (Instituto Nacional de Pesquisas Espaciais), que oferece o Modelo Digital de Elevação (MDE) do terreno numa resolução espacial de 30 x 30 m cada pixel.

Posteriormente, foi construído em SIG, no software Quatum Gis ${ }^{\circledR}$ 2.8.2, um arquivo/imagem com o mosaico de 26 cenas, cobrindo todo o território do estado do Piauí. Os dados foram georreferenciados no sistema de projeção LatLong (graus decimais) e Datum WGS84, na escala 1:250.000.

Em seguida, reprojetou o mosaico para o sistema UTM (em metros), para que os algoritmos gerassem o MDE com informações referentes à declividade, expressas na forma de porcentagem. A ferramenta utilizada para a geração do MDE de declividade, é denominado de MDE (Modelo digital de elevação).

De posse do MDE de declividade, prosseguiu classificando o arquivo matriz conforme os parâmetros de aptidão de declividade. O arquivo foi classificado com duas classes: aptas (área com declividade < 12\%) e não aptas (áreas com declividade > 12\%), tendo como resultado o mapa de aptidão para fins de mecanização da cana-de-açúcar.

Posteriormente, vetorizou o arquivo classificado para recorte e união com a malha municipal do IBGE, conforme descrito anteriormente.

\subsection{Estimativa de lâminas de irrigação para cana-de-açúcar}

$\mathrm{Na}$ elaboração do mapa de lâminas de irrigação, foi utilizado o banco de dados pluviométricos para o Estado do Piauí, de 87 postos pluviométricos, com série histórica de 15 anos, permitindo assim a elaboração do balanço hídrico diário utilizando o método de Thornthwaite e Mather (1955). Conforme dito anteriormente, não se disponibilizou de dados de temperatura média do ar medidos para todos os postos pluviométricos. Desta forma, utilizando a metodologia de Lima e Ribeiro (1998), 
obteve os valores estimados de temperaturas do ar média mensal, considerando os mesmos para cada dia do respectivo mês.

A precipitação efetiva foi estimada por meio de uma percentagem fixa de $75 \%$ das precipitações totais diárias, utilizando a CAD (Capacidade de Armazenamento de Água) como valor limitante, conforme realizado nos trabalhos de Mousinho (2008) e Oliveira (2014), seguindo adaptação de Embrapa (2003). Dessa forma, a precipitação efetiva foi calculada seguindo as equações a seguir.

$$
\begin{aligned}
& \mathrm{P}_{\mathrm{efi}}=\mathrm{P}_{\mathrm{ti}}, \text { se } \mathrm{P}_{\mathrm{ti}} \leq \mathrm{CAD} \\
& \mathrm{P}_{\mathrm{efi}}=0,75 \mathrm{P}_{\mathrm{ti}}, \text { se } \mathrm{P}_{\mathrm{ti}}>\text { CAD }
\end{aligned}
$$

em que: $\mathrm{P}_{\text {efi }}$ é precipitação efetiva ocorrida no dia i (em L);

Pti é precipitação total ocorrida no dia i (em L).

A evapotranspiração potencial (ETo) diária, foi estimada pelo método de Thornthwaite (1948), que tem como base de cálculo a temperatura média do ar. Para a obtenção da ETo em escala diária, dividiu o valor da ETo mensal pelo número de dias do respectivo mês. Partindo-se do princípio de que os valores diários de ETo não apresentariam alterações significativas de um ano para outro, considerou que os mesmos valores de ETo de um determinado dia do ano foi igual para o mesmo dia de todos os anos da série histórica.

Os parâmetros utilizados no balanço hídrico do cultivo $(\mathrm{BH})$ seguiram os mesmos indicados pelo zoneamento de risco climático elaborado pelo Ministério da Agricultura e Abastecimento (MAPA) (BRASILb, 2015). Dessa forma, os valores de capacidade de água disponível (CAD) adotados foram de 75, 100 e 125 mm, denominado de solos Tipo 1 (textura arenosa), Tipo 2 (textura média) e Tipo 3 (textura argilosa), respectivamente. Os valores de coeficiente de culturas $(\mathrm{Kc})$ e suas respectivas fases de desenvolvimento, adotados, podem ser visualizados na tabela 2. Considerou-se o valor da profundidade efetiva do sistema radicular da cana-de-açúcar igual a 0,60 m em todo o ciclo da cultura, conforme recomendado por Farias et al. (2008). 
Tabela 2 - Valores de coeficiente de cultura (Kc) nas respectivas fases de desenvolvimento da cana-de-açúcar

\begin{tabular}{lcc}
\hline Período de desenvolvimento & Dias após emergência & Kc \\
\hline Do plantio até 0,75 de cobertura & 0 a 60 & 0,90 \\
Máximo uso de água & 60 a 210 & 1,15 \\
Início da senescência & 210 a 270 & 1,05 \\
Maturação & 270 a 360 & 0,70
\end{tabular}

Fonte: Bernardo (2006) apud BRASILb (2015).

A Evapotranspiração da cultura (ETc) foi calculada conforme equação a seguir:

$$
\mathrm{ETc}=\mathrm{ETp} \times \mathrm{Kc}
$$

em que: ETc é a evapotranspiração da cultura $\left(m m \cdot d_{i a}{ }^{-1}\right)$;

ETp é a evapotranspiração potencial $\left(\mathrm{mm} \cdot \mathrm{dia}^{-1}\right)$;

Kc o coeficiente da cultura, ver tabela 3 (adimensional).

Nos balanços hídricos estimou-se uma lâmina bruta que elevasse o armazenamento de água no solo à capacidade de campo, visando a irrigação antes que a cultura atingisse o ponto de murcha. De acordo com Pereira, Angelocci e Sentelhas (2002) apud Mousinho, Andrade Júnior e Frizzone (2008), nesse momento um percentual da CAD é denominada de Água Facilmente Disponível (AFD). AFD é a fração da água total disponível, que facilmente pode ser retirada do solo pela cultura, a partir do seu armazenamento máximo, sem que haja algum déficit hídrico à cultura. Ela é o resultado do produto entre o fator de disponibilidade (f) e a CAD, (equação 4).

$$
\mathrm{AFD}=\mathrm{f} \times \mathrm{CAD}
$$

em que: AFD é a água facilmente disponível (em L);

f é a fração de esgotamento da água no solo (adimensional);

CAD é a capacidade de água disponível no solo (em L).

Seguindo recomendações de Doorenbos \& Kassam (2000), o BH considerou a irrigação da cana-de-açúcar, assim que a água facilmente disponível 
foi consumida, assim, a fração de esgotamento da água no solo (f) utilizada foi 0,2, ou seja, a irrigação seria realizada quando a planta consumisse $20 \%$ da água disponível no solo.

No cálculo da lâmina bruta de irrigação, considerando que a cultura seria irrigada por gotejamento, considerou-se a eficiência do mesmo igual a 90\%. A adoção do sistema de irrigação por gotejamento, é justificado pelos bons resultados, que o mesmo alcançou em estudos conduzidos pela Embrapa na Usina Comvap Açúcar e Álcool Ltda (União - Pi), observada no trabalho de Andrade Júnior (2012).

Os BH's foram processados por meio de planilhas eletrônicas, com auxílio da ferramenta Macro disponível no Excel (Microsoft). Os resultados de lâmina brutas foram submetidos a análise estatística seguindo o teste de aderência de Kolmogorov-Smirnov, ao nível de significância de 5\%, para as séries de lâminas brutas obtidas nos BH's. Em seguida, considerando o ajuste dos dados à distribuição de probabilidade normal, a partir dos valores da média e desvio padrão, procedeu-se a realização das simulações utilizando o método de Monte Carlo. Assim, foram simulados mil valores de lâminas bruta de irrigação da cana-de-açúcar para cada combinação de mesesde plantio e CAD. Em seguida foram calculadas as lâminas brutas de irrigação para o ciclo da cana-de-açúcar com probabilidade de ocorrência de 75\%, para as mesmas combinações acima e para cada local.

Os valores de lâminas brutas de irrigação necessária para o ciclo da cana-de-açúcar, para os 12 meses de plantio (janeiro a dezembro), para as CAD’s 75, 100 e $125 \mathrm{~mm}$ foram geoespacializados para o Estado do Piauí utilizando-se o software Quantum Gis ${ }^{\circledR}$, totalizando 36 mapas temáticos de lâminas brutas. Os dados foram importados e geoespacializados no SIG seguindo a mesma metodologia, descrita anteriormente, para o mapa temático de temperatura média do ar. Os valores de lâminas brutas foram classificados em cinco intervalos: 800 a $1160 \mathrm{~mm} ; 1160$ a $1520 \mathrm{~mm} ; 1520$ a $1880 \mathrm{~mm} ; 1880$ a $2240 \mathrm{~mm}$ e 2240 a $2600 \mathrm{~mm}$.

\subsection{Zoneamento agrícola para cana-de-açúcar irrigada}

Os mapas do zoneamento agrícola para cana-de-açúcar irrigada foram resultados do cruzamento entre os mapas temáticos de declividade e lâmina bruta 
de irrigação por gotejamento. Como o mapa temático de temperatura média do ar, teve como resultado aptidão térmica de todo o Estado, o mesmo não foi incluído no cruzamento do zoneamento.

O cruzamento dos mapas temático vetorizado foi realizado por meio da ferramenta Intersecção, no Quantum Gis ${ }^{\circledR}$. A ferramenta é responsável por calcular a intersecção geométrica dos mapas de entrada.

Todos os mapas foram gerados no datum SIRGAS 2000 de acordo com os novos padrões cartográficos brasileiros, numa escala 1:250.000. 


\section{RESULTADOS E DISCUSSÃO}

\subsection{Aptidão térmica}

Os valores de temperatura média mensal estimadas apresentaram valores variando de 25 a $28{ }^{\circ} \mathrm{C}$, indicando aptidão térmica para a cana-deaçúcar em todo o Estado (figura 2).

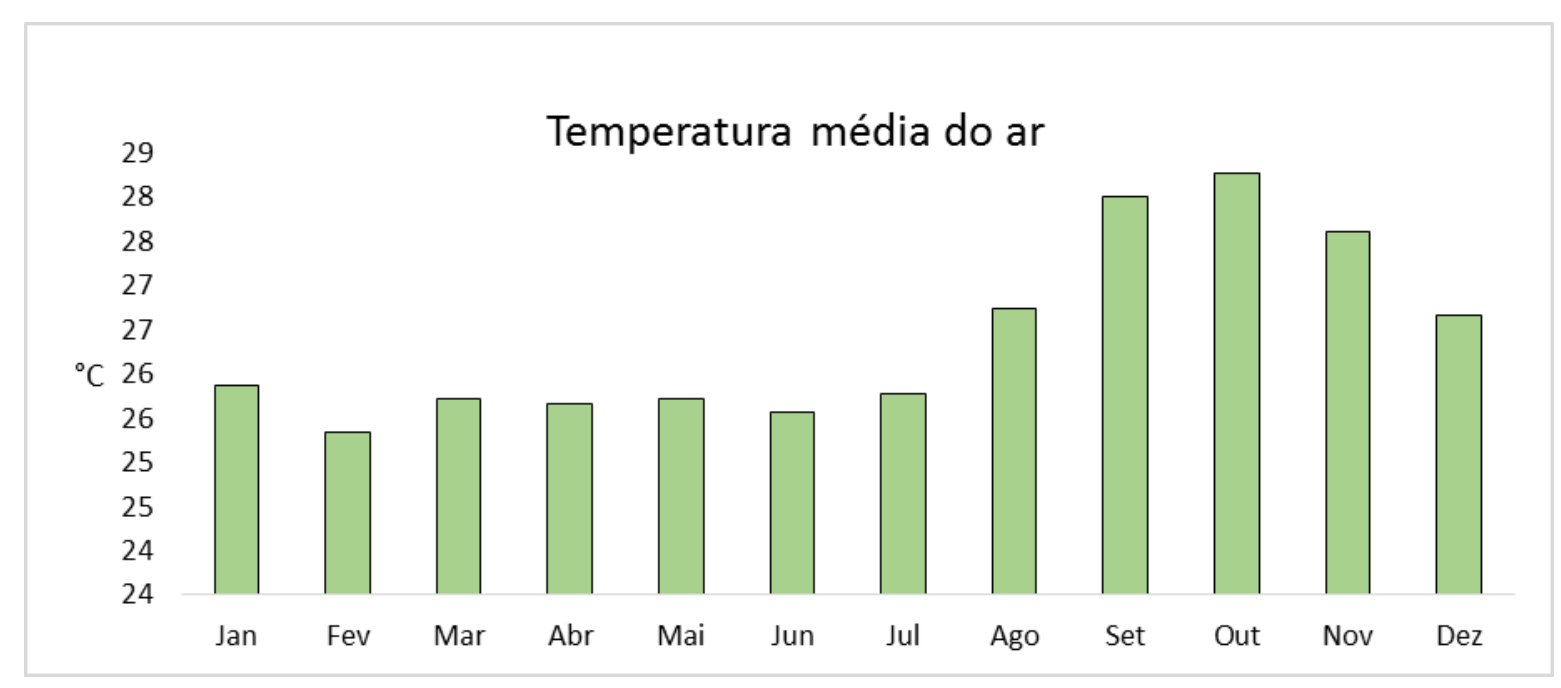

Figura 2 - Gráfico de temperatura média do ar mensal para o estado do Piauí Fonte: Silva, C. O da (2016).

Os valores mais elevados de temperatura média do ar foram observados de setembro a novembro, em todo o Estado, com valores variando de $27^{\circ} \mathrm{C}$ a $28^{\circ} \mathrm{C}$, período considerado o mais seco. $\mathrm{O}$ menor valor de temperatura foi observado no mês de fevereiro, no momento em que em que ocorre o período chuvoso no Estado. 
$\mathrm{Na}$ figura 3 observou-se valores de temperatura média do ar anual compreendidos entre 22,5 a $29,5^{\circ} \mathrm{C}$. A classe de temperatura média do ar anual de 26 a $27,7^{\circ} \mathrm{C}$ foi a que predominou em todo o Estado, correspondendo a $64,2 \%$ de todo o território.

As menores temperaturas média anual foram observadas na região fronteira com o Ceará, central, sudeste e extremo sul do Estado. Nessas regiões encontram-se as serras mais altas. As baixas temperaturas podem ser justificadas pela presença de um valor de umidade do ar bem maior que no restante do Estado, alta altitude e chuvas mais regulares.

As maiores temperaturas média anuais do ar foram de 27,7 a $29,5^{\circ} \mathrm{C}$, predominantes nos municípios de Barras, Canto do Buriti e Uruçuí, localizados nas regiões norte e sudeste. Esses valores de temperatura média do ar anual, encontra-se muito próximo do que foi observado por Andrade Júnior et al. (2004) no Altas Climatológico elabora para o Piauí, que indica as maiores temperaturas médias do ar anual variando de 28 e $30^{\circ} \mathrm{C}$. 


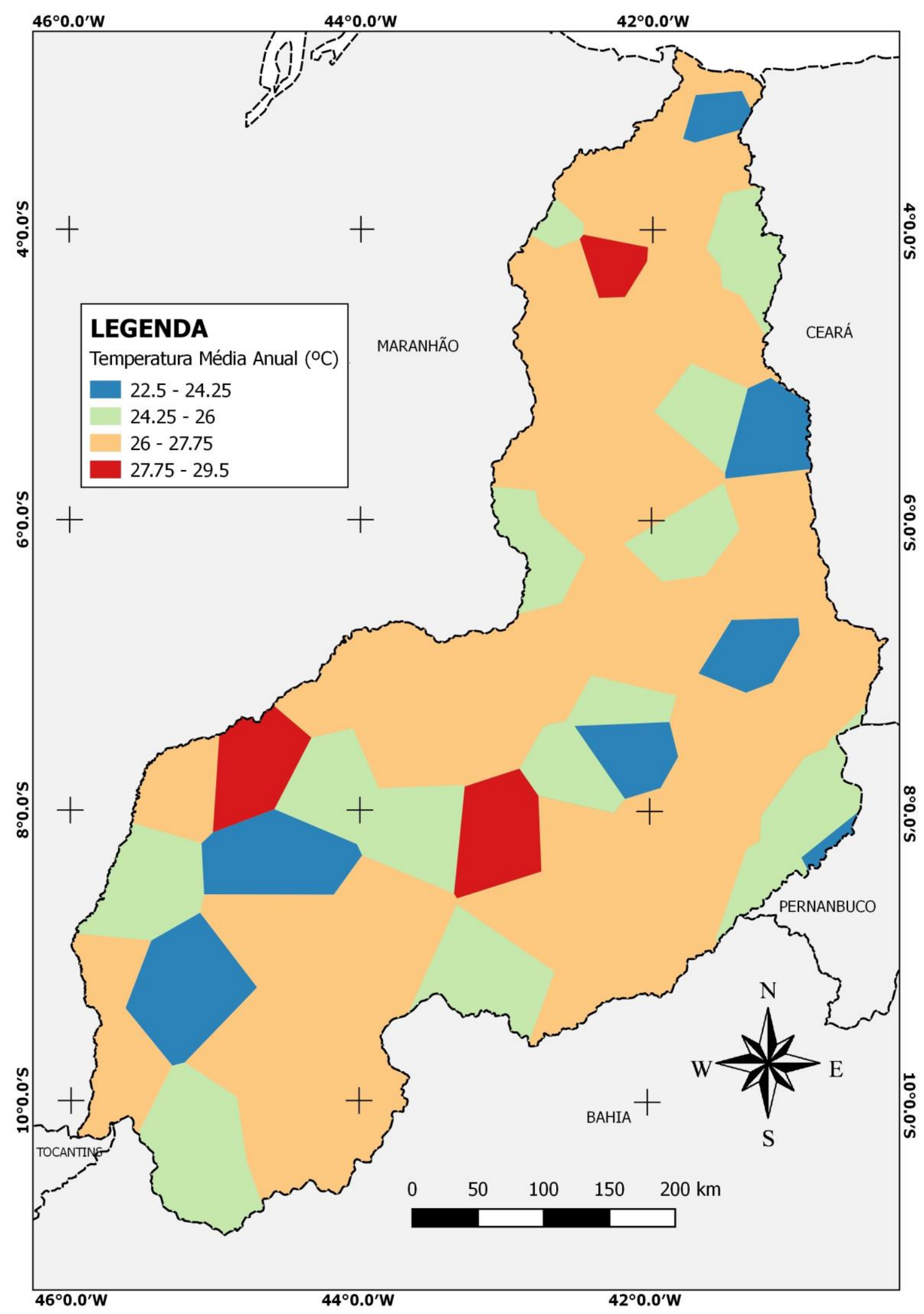

Figura 3 - Mapa de temperatura média do ar anual do estado do Piauí Fonte: Silva, C. O da (2016). 
Na figura 4 pode ser visualizado o mapa temático para aptidão térmica, com dados de temperatura média anual da cana-de-açúcar para o estado do Piauí. Nota-se que a temperatura média do ar não é um fator limitante para o cultivo da cana-de-açúcar, pois todo o Estado encontra-se dentro do critério de aptidão térmica menor que $21^{\circ} \mathrm{C}$, de acordo com as recomendações do MAPA (BRASILb, 2015). Os resultados, também, estão dentro dos critérios térmicos estabelecidos no Zoneamento Agroecológico da cana-de-açúcar (ZAE) elaborado por Manzatto et al. (2009) que define temperaturas médias do ar maiores que $19^{\circ} \mathrm{C}$, como um dos critérios a considerar aptidão climática para o cultivo no Brasil.

Resultados semelhantes aos do presente trabalho, foram observados por Waldheim et al. (2006), quando elaboraram o zoneamento climático da cana-de-açúcar, de sequeiro, para alguns municípios da região Nordeste do Brasil. Os municípios piauienses Picos e Paulistana, analisados por eles, no trabalho, apresentaram nenhuma restrição térmica, para o cultivo da cultura.

No município de União, onde encontra-se a única usina em atividade do Estado produtora de etanol e açúcar (COMVAP), observou temperatura média anual de $27^{\circ} \mathrm{C}$, portanto, dentro da aptidão térmica exigida pela cultura. 


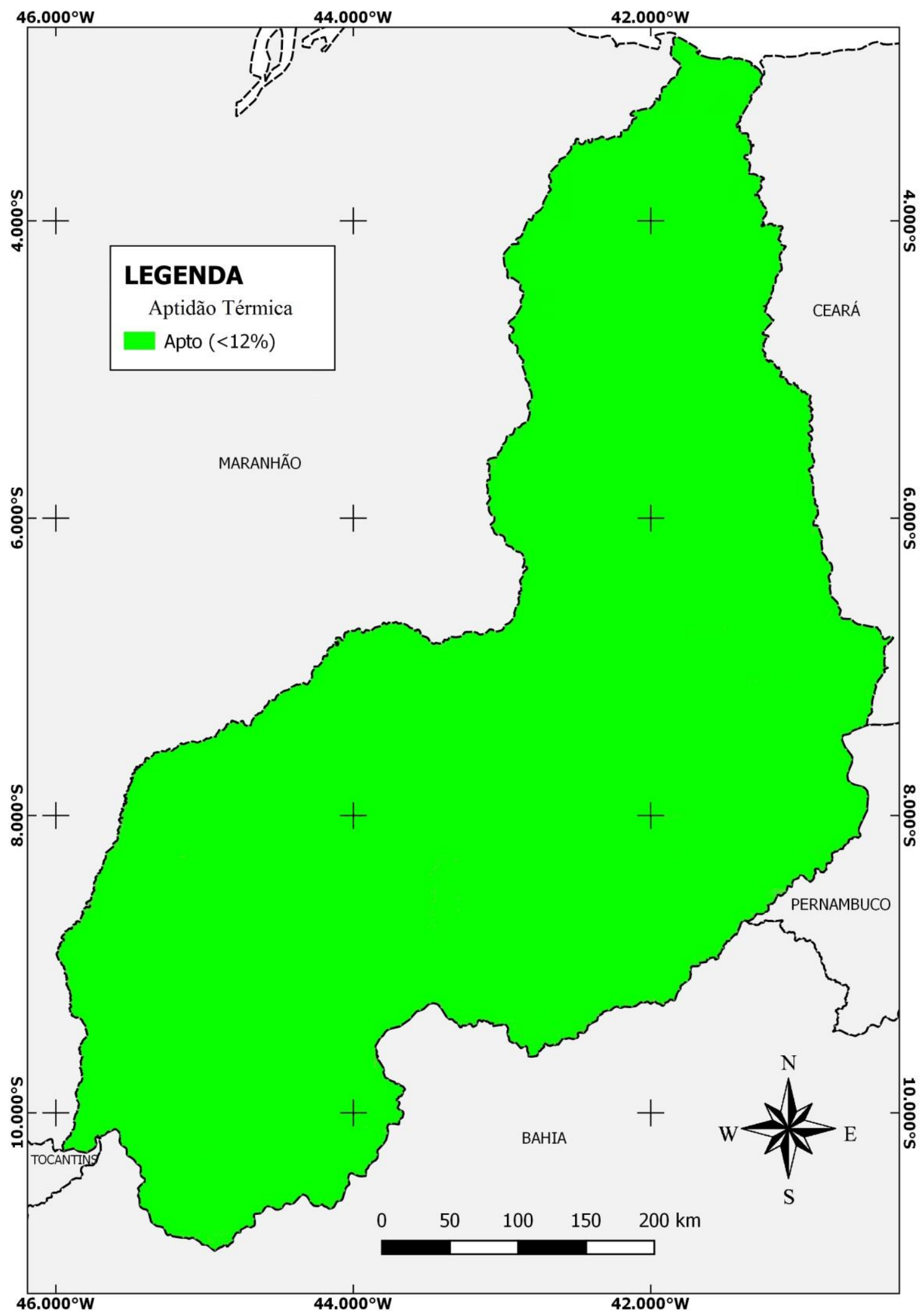

Figura 4 - Mapa temático de aptidão térmica para o cultivo da cana-de-açúcar no estado do Piauí

Fonte: Silva, C. O da (2016). 


\subsection{Aptidão para fins de mecanização - Declividade}

De acordo com a figura 5 observa-se que o estado do Piauí apresenta com grande potencial para utilização de máquinas agrícolas no cultivo da cana-de-açúcar. Do total de área, aproximadamente $222.263,3 \mathrm{~km}^{2} \quad(88,3 \%)$ apresentaram-se aptas para fins de mecanização agrícola, com declividade inferior a 12\%. Em 11,7\% das terras, aproximadamente $29450,5 \mathrm{~km}^{2}$, não recomenda-se para fins de mecanização, quando se leva a declividade como critério único para estabelecimento de grandes máquinas agrícolas, pois possuem valores acima de $12 \%$.

Apesar da sua média a baixa fertilidade, os solos do Piauí apresentam grande potencial agrícola graças às condições físicas e de topografia pouco movimentada (PIBH, 2008). Dessa forma, o Estado tem uma grande área em que pode ser utilizado para atividades agrícolas utilizando mecanização. No período entre 1970 e 2006, se constata uma elevação significativa no uso da terra para lavouras e o crescimento da mecanização agrícola, com uma elevação de 1431,6 \% apenas no uso de tratores (PIAUÍ, 2010).

Utilizando o mesmo critério para aptidão de área mecanizadas, o Relatório do Estudo sobre as Possibilidades e Impactos da Produção de Grandes Quantidades de Etanol, no Brasil, elaborado pelo Centro de Gestão de Estudos Estratégicos, observou que há uma condição de relevo muito favorável para operações mecanizadas, bem como para a distribuição de vinhaça e água para as áreas localizadas no Piaú, na região do município de Santa Filomena (CGEE, 2009). Resultados semelhantes a esses podem ser visualizados no mapa de aptidão para mecanização, no presente trabalho. A exceção, para a região de Santa Filomena, encontra-se na Serra Grande e na Serra de Uruçuí. Na região sudeste do Estado temos as Chapada dos Gerais, Serra Vermelha e Serra de Bom Jesus do Gurguéia, abrangendo uma maior concentração de área inapta para a mecanização.

$\mathrm{Na}$ região central do Estado, a Serra da Fava Preta, regiões próximas a Serra e próximo a capital Teresina, foi onde houve maior predomínio de áreas inaptas. De acordo com os dados gerados, o município de União, encontra-se com $56 \%$ de seu território inapto para mecanização agrícola. Segundo estudos de Moraes (2004), para o município de Teresina, observou que essa região possui chapadas baixas 
com alta declividade. As chapadas abrangem, também, o município de União. A Comvap encontra-se dentro dos $44 \%$ da área apto a mecanização. A região norte apresentou grande áreas territoriais aptas a mecanização. Essas regiões aptas se concentram mais ao centro da região. As áreas inaptas, da região norte foram observadas nas Serra da Ibiapaba e da Serra dos Matões e em suas aproximidades.

No ponto de vista ambiental, Torquato, Jesus e Zorzo (2015), relatam que a mecanização agrícola do plantio e colheita da cana-de-açúcar traz benefícios de sustentabilidade como: o fim da emissão de poluentes por queima dos canaviais; trabalho mais leve para os trabalhadores da lavoura; maior produtividade; e a utilização do palhiço como fonte de energia e nutrientes para o solo (cobertura vegetal). Dessa forma, se faz necessário o estudo dessa variável para o zoneamento da cana-deaçúcar. 


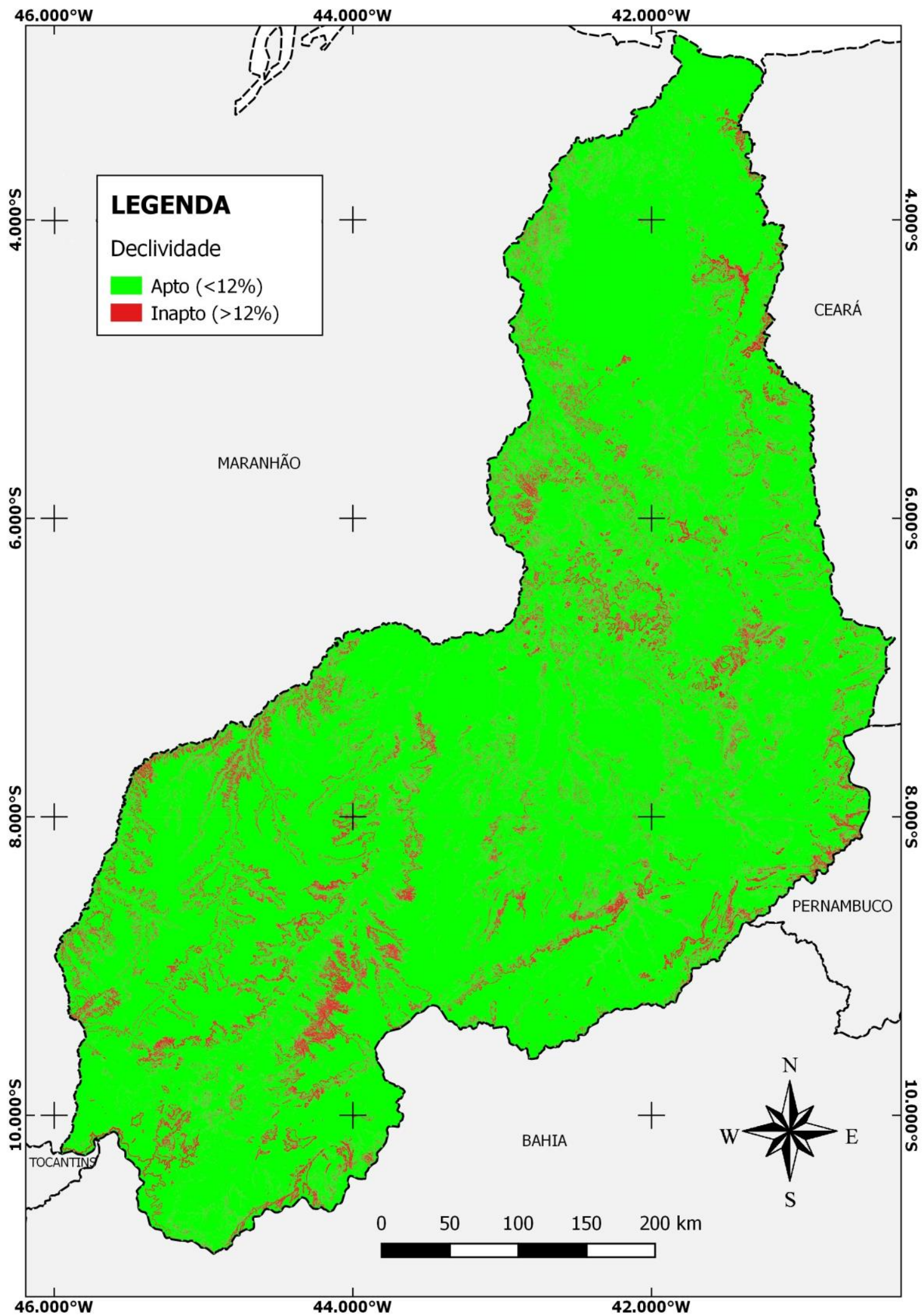

Figura 5 - Mapa temático de aptidão para fins de mecanização para cana-de-açúcar irrigada no estado do Piauí, tendo como referência da declividade Fonte: Silva, C. O da (2016). 


\subsection{Lâminas bruta de irrigação}

Analisando as figuras 6, 7 e 8 das CAD's 75, 100 e $125 \mathrm{~mm}$, observou que a medida que se aumenta o valor da CAD aumenta a área com a menor classe de lâmina bruta de irrigação por gotejamento (800 a $1.160 \mathrm{~mm}$ ) exigida pela cana-de-açúcar, isso foi apresentado em todos os meses de plantio analisadas. Por outro lado, observa-se redução da área das classes de intervalos de lâminas brutas de irrigação maiores, 1.520 a $1.880 \mathrm{~mm}$ e 1.880 a $2.240 \mathrm{~mm}$. Isso ocorre em virtude do aumento da capacidade de armazenamento de água do solo quando se eleva a CAD fazendo predominar um intervalo de lâmina de irrigação inferior.

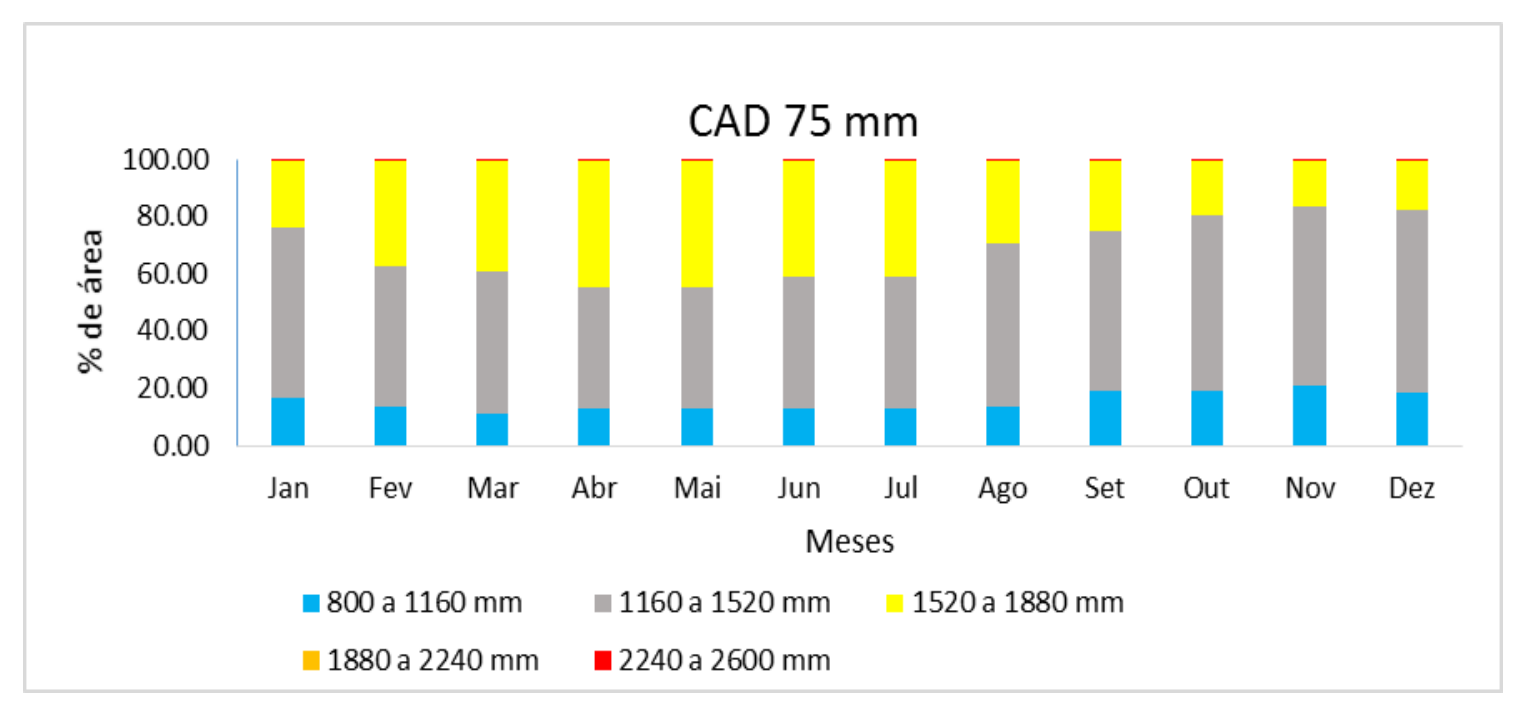

Figura 6 - Percentuais de área do Estado do Piauí referentes às classes de lâminas brutas de irrigação da cana-de-açúcar em solos com capacidade de água disponível de $75 \mathrm{~mm}$, para cada data de plantio

Fonte: Silva, C. O. da, 2016. 


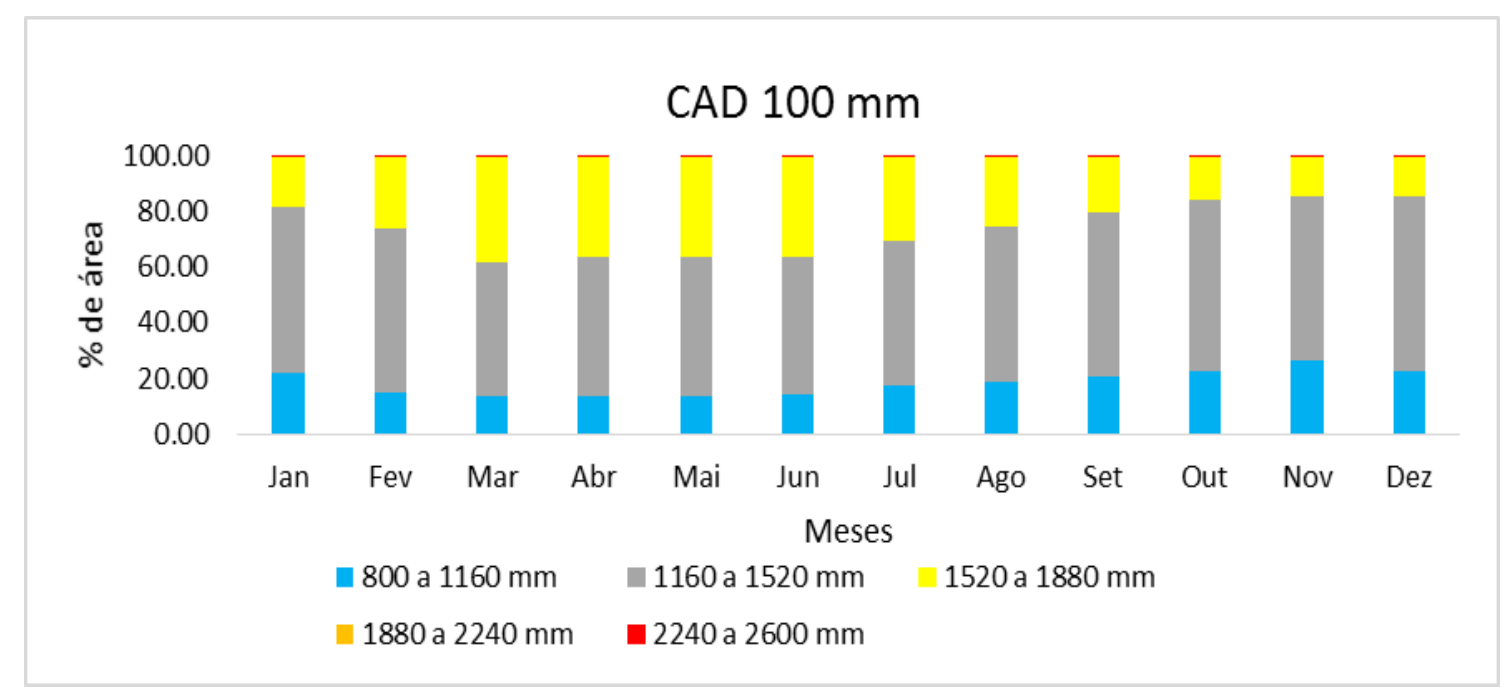

Figura 7 - Percentuais de área do Estado do Piauí referentes às classes de lâminas brutas de irrigação da cana-de-açúcar em solos com capacidade de água disponível de $100 \mathrm{~mm}$, para cada data de plantio

Fonte: Silva, C. O. da, 2016.

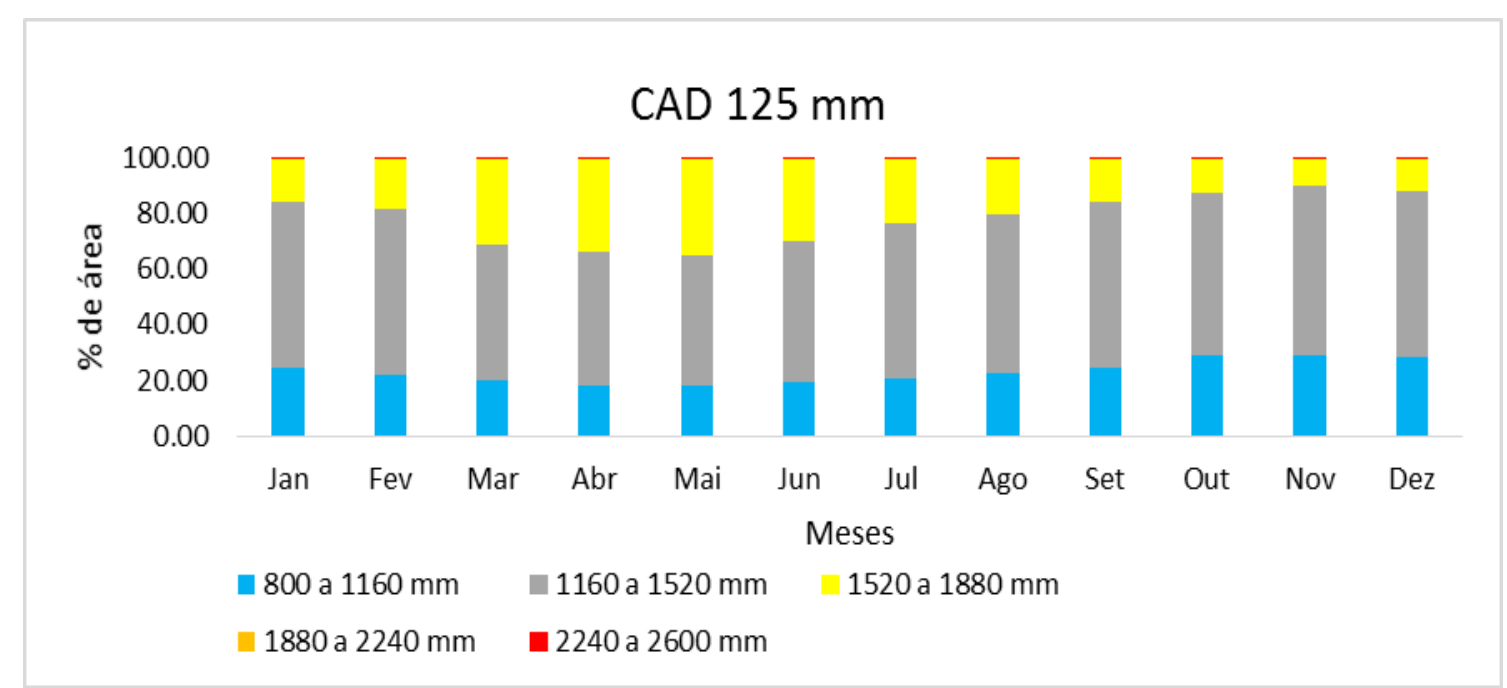

Figura 8 - Percentuais de área do Estado do Piauí referentes às classes de lâminas brutas de irrigação da cana-de-açúcar em solos com capacidade de água disponível de $125 \mathrm{~mm}$, para cada data de plantio

Fonte: Silva, C. O. da, 2016.

A maior área do Estado encontra-se dentro da classe de 1.160 a $1.520 \mathrm{~mm}$ em todas as CAD's analisadas, quando o plantio é feito nos meses de agosto, setembro, outubro, novembro e dezembro, se somado todas as áreas dos demais intervalos de classes analisados. Marin (2015), afirma que novos estudos apontam para um consumo hídrico da cana-de-açúcar de $1.200 \mathrm{~mm}$ a $1.300 \mathrm{~mm}$, esse valor de 
consumo encontra-se dentro do intervalo da classe citada, sendo a mesma o segundo menor intervalo de classes.

De acordo com a figura 6, o plantio realizado nos meses de abril e maio, em um solo de CAD $75 \mathrm{~mm}$, apresenta os intervalos de classes de lâminas brutas de 1.160 a $1.520 \mathrm{~mm}$ e 1.520 a $1.880 \mathrm{~mm}$ com porcentagem de áreas bem semelhantes, de 42,59\% e 42,69\% da área territorial, respectivamente. Nas CAD's 100 e $125 \mathrm{~mm}$ o predomínio da classe 1.160 a $1.520 \mathrm{~mm}$, no estado do Piauí, foi observada em todos os meses de plantio.

A classe de lâmina bruta que está compreendida entre 1.880 a $2.240 \mathrm{~mm}$, apresenta-se em uma área em abrange parte dos municípios de Cajueiro da Praia e Luiz Correia (região norte) e correspondendo a $0,11 \%$ do território do Estado, nos meses de maio a julho, apenas na CAD $75 \mathrm{~mm}$. Na CAD $100 \mathrm{~mm}$ permaneceu a mesma área somente no mês de maio. Isso se deve a redução da área com lâminas brutas maiores, pois em uma CAD maior existe uma maior retenção de água no solo, exigindo uma lâmina de irrigação menor.

A área que abrange partes dos municípios de Acauã, Betânia do Piauí e Curral Novo do Piauí, localizados no sudeste do Estado, região semiárida, permaneceu constante, em todos os meses de plantio, com a maior lâmina bruta que varia entre 2.240 a $2.600 \mathrm{~mm}$, totalizando $0,19 \%$ do território estadual.

De acordo com Rossato (2001), em sua análise de umidade do solo, com os dados do projeto RADAM Brasil, apresenta a CAD de $75 \mathrm{~mm}$ como predominante no semiárido piauiense. Sendo assim, conforme figura 6, essa região apresenta a predominância das menores lâminas brutas (classes 800 a 1.160 mm e 1.520 a $1.880 \mathrm{~mm}$ ) quando o cultivo é iniciado em dezembro início do período chuvoso ocorrendo uma ampliação da área ocupada por lâminas maiores de 1520 a 1880 mm, nos demais meses do período chuvoso, janeiro e fevereiro, indicando que a quantidade de precipitações ocorrida nessa região ainda não é suficiente para o pleno desenvolvimento da cana-de-açúcar.

Para uma melhor discussão dos dados da espacialização da lâmina bruta de irrigação, decidiu-se fazer a análise das por regionalização do Estado. Como referência de regionalização optou-se pela classificação de mesoregiões elaborada por Araújo (2006) que dividiu o Estado em: centro-norte piauiense, norte piauiense, sudeste piauiense e sudoeste piauiense. 


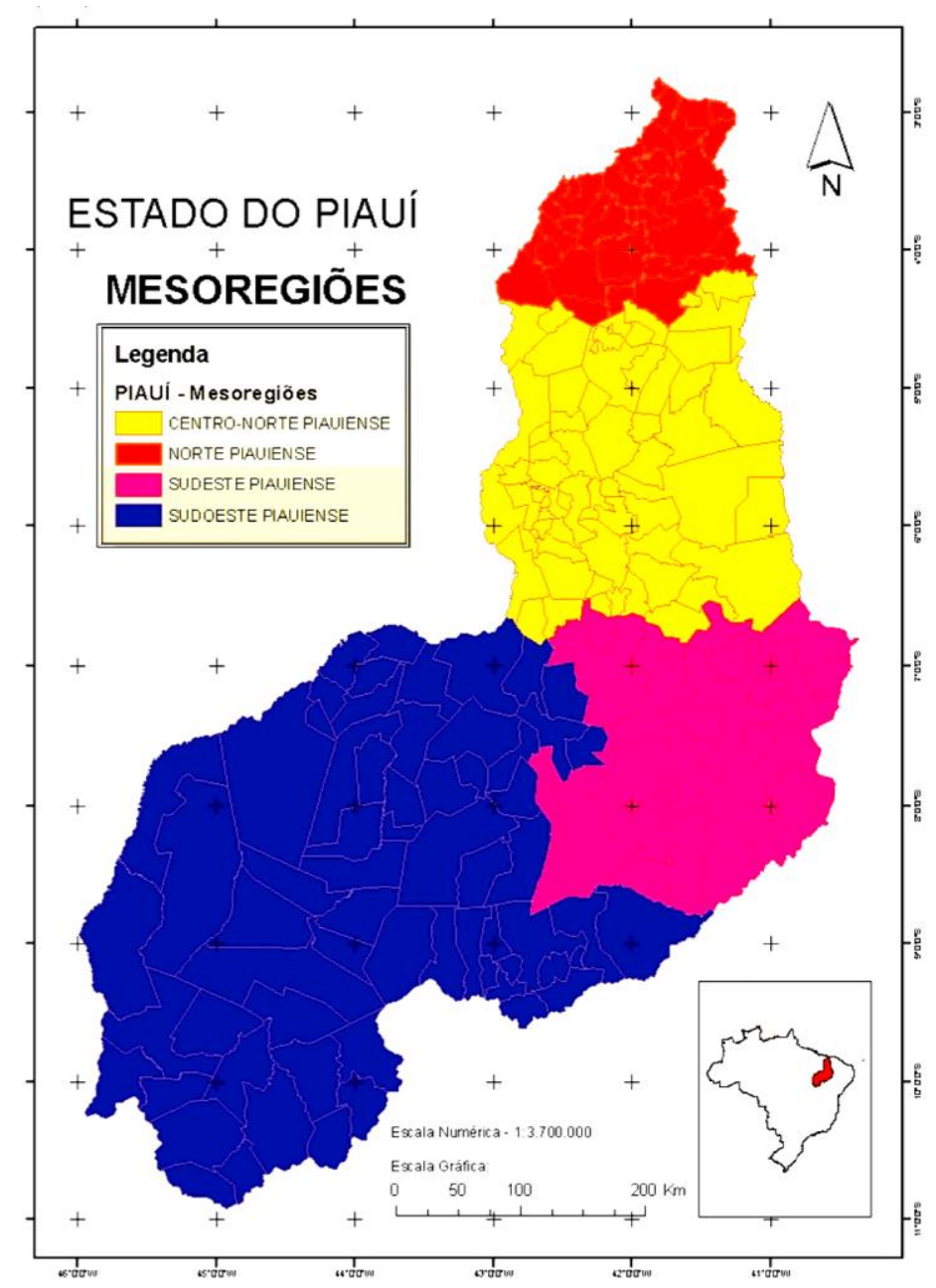

Figura 9 - Mapa das mesoregiões de estado do Piauí

Fonte: Araújo, J. L. L. (2006).

Na CAD 75 mm, observa-se que a mesoregião norte do Estado, apresenta sua menor lâmina bruta, classe de 1.160 a $1.520 \mathrm{~mm}$, em maior extensão territorial na data de plantio de dezembro (figura 10). Dessa forma, em virtude da exigência de aplicação de uma lâmina de irrigação não muito elevada, o mês de dezembro é a melhor data de plantio para cana-de-açúcar, em maior parte da mesoregião norte. Nas CAD's 100 e $125 \mathrm{~mm}$, verifica-se que a classe 1.1160 a $1.520 \mathrm{~mm}$ apresentaram as maiores áreas nos meses de plantio nos meses de outubro, novembro e dezembro (figuras 11 e 12). O intervalo maior de lâmina bruta apresentada foi de 1.520 a $1.880 \mathrm{~mm}$, em maiores áreas nos meses de plantio de abril, maio, indicando as mesmas como os piores meses para o plantio da cana na região. A data de maio, se apresentou, também, como a pior, na maior parte da região norte nas CAD's 100 e 125 $\mathrm{mm}$. 
Na mesoregião centro-norte, onde está localizado a Comvap (município de União) e a capital Teresina, a menor lâmina bruta com maior área foi observada na data de novembro, com intervalo de classe entre 1.160 a $1.520 \mathrm{~mm}$. Para os municípios de União e Teresina, os melhores meses para o plantio apresentadas foram: janeiro, setembro, outubro, novembro e dezembro. Analisando as CAD's 100 e $125 \mathrm{~mm}$ percebe-se que os meses de plantio permaneceram as mesmas da CAD $75 \mathrm{~mm}$ com o acréscimo da data de fevereiro. Barros et al. (2011), em seu trabalho, indicou o plantio da cana-de-açúcar em setembro uma máxima produtividade média de colmos (150,69 Mg.ha $\left.{ }^{-1}\right)$, com a menor lâmina aplicada para o município de Teresina, em um sistema de irrigação por aspersão. A simulação foi feita em um Argissolo VermelhoAmarelo, que segundo Moraes (2004), corresponde a CAD de 100 mm. Embora o sistema de irrigação analisado por esse trabalho seja diferente do que foi utilizado por Barros et al. (2011), setembro se mostrou com uma boa data de plantio em ambos os trabalhos.

Andrade Júnior et al. (2012), em trabalho desenvolvido na Comvap, encontrou uma produtividade máxima de colmos e açúcar, com uma lâmina bruta de $1.154 \mathrm{~mm}$, valor muito próximo ao apresentado no presente trabalho, para a mesma região, no mesmo período de plantio (setembro), para todas as CAD's analisadas. A pouca diferença verificada entre a lâmina de $1.154 \mathrm{~mm}$ e o intervalo de classe de 1.160 a 1.520 mm pode ser justificado pela antecipação do corte da cana-deaçúcar devido ao acamamento.

A mesoregião sudeste do Estado, a CAD $75 \mathrm{~mm}$, apresenta em sua área o predomínio da classe 1.520 a $1.880 \mathrm{~mm}$. Essa classe tem sua área reduzida nos meses de plantio: outubro, novembro, dezembro e janeiro. Sendo que os meses de dezembro e janeiro onde pode ser encontrado a menor classe de lâmina bruta analisada em uma extensão territorial maior (800 a 1.160 mm). As maiores áreas, em dezembro e janeiro, encontram-se no intervalo de classe de lâmina bruta de 1.160 a $1.520 \mathrm{~mm}$, indicando que esse período (dezembro e janeiro) é o melhor período para o cultivo da cana na maior parte da região. Esse mesmo comportamento pode ser observado nas CAD's 100 e $125 \mathrm{~mm}$ com o acréscimo da data de novembro. Apenas CAD $125 \mathrm{~mm}$ indica mais dois meses de plantio, novembro e fevereiro, para o cultivo da cana na maior parte da região. 
Em termos de lâminas e considerando o CAD $100 \mathrm{~mm}$, os resultados estão de acordo com Gava et al. (2011), que observaram para o município de Jaú, SP, um incremento médio de $24 \%$ na produção de colmos e de $23 \%$ na de açúcar, com a lâmina de $1.714 \mathrm{~mm}$, inserida no intervalo de 1.520 a $1.880 \mathrm{~mm}$ verificada na maior área do sudeste do estado do Piauí.

Na mesoregião sudoeste, a maior área de predominância dos menores intervalos de classes de lâminas brutas analisadas (800 a $1.160 \mathrm{~mm}$ e $1.160 \mathrm{a}$ $1.520 \mathrm{~mm}$ ), na CAD $75 \mathrm{~mm}$, foi encontrada nos meses de plantio: janeiro, agosto, setembro, outubro, novembro e dezembro. Nas CAD's 100 e $125 \mathrm{~mm}$, os meses permanecem com o acréscimo de fevereiro e julho. Na CAD $125 \mathrm{~mm}$, além dos meses já mencionadas foi observado julho como uma boa data de plantio para maioria da região.

No extremo da mesoregião sudoeste do Estado, fronteira com o Maranhão, a menor lâmina bruta de irrigação (800 a $1.160 \mathrm{~mm}$ ) permaneceu presente em todos os meses de plantio e CAD's analisadas. Essa região foi indicada pelo ZAE como área de expansão para a cana-de-açúcar em sequeiro, compreendendo a região de cerrado denominada de MATOPIBA, que está sendo contemplada com programas governamentais de incentivo à irrigação.

Em todas as CAD's analisadas, nas regiões sudeste e norte do Estado, não se observou a presença do menor intervalo de classe de lâmina bruta, 800 a $1.160 \mathrm{~mm}$, em todos os meses de plantio, conforme verificado nas demais regiões do Piauí. O contrário, ocorreu nas regiões sudeste e centro-norte, onde a menor classe de lâmina bruta analisado no trabalho, se mostrou presente em todos os meses de plantio. 


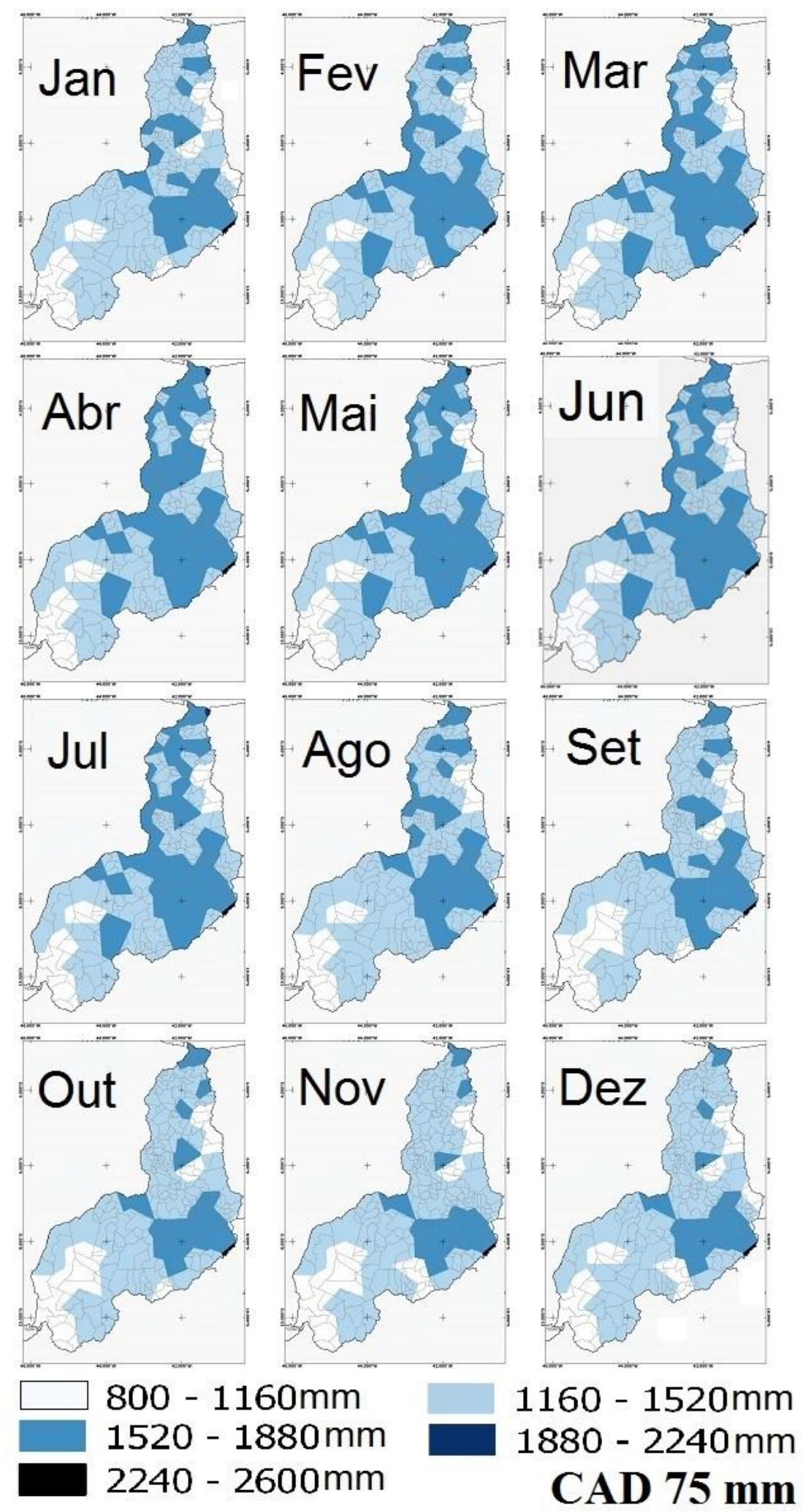

Figura 10 - Espacialização de lâmina bruta de irrigação por gotejamento, da cana-deaçúcar, especializadas para 12 meses de plantio em solos com capacidade de água disponível de $75 \mathrm{~mm}$, para o estado do Piauí Fonte: Silva, C. O. da, (2016). 


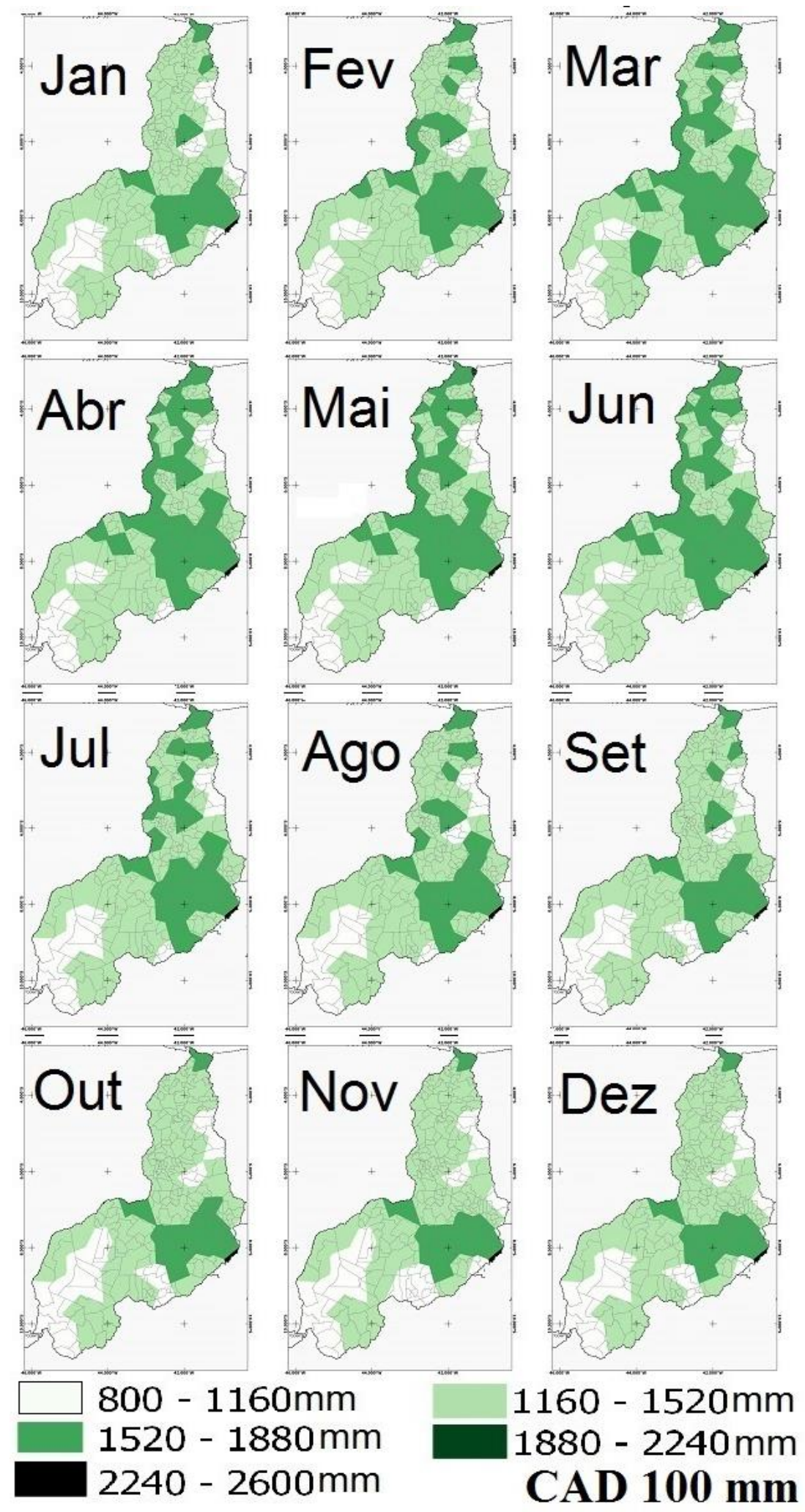

Figura 11 - Espacialização de lâmina bruta de irrigação por gotejamento, da cana-deaçúcar, especializadas para 12 meses de plantio em solos com capacidade de água disponível de 100 mm, para o estado do Piauí Fonte: Silva, C. O. da, (2016). 


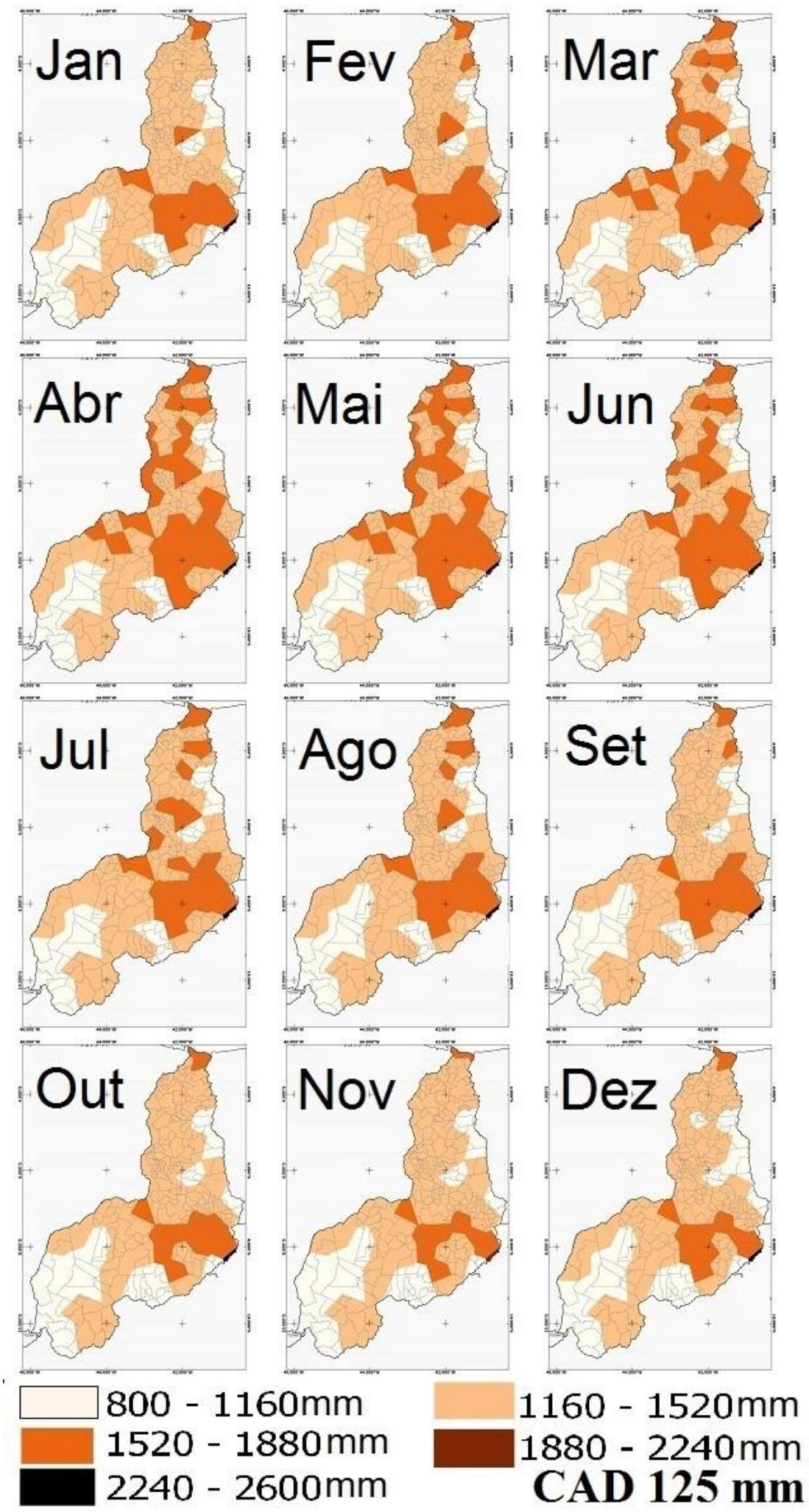

Figura 12 - Espacialização de lâmina bruta de irrigação por gotejamento, da cana-deaçúcar, especializadas para 12 meses de plantio em solos com capacidade de água disponível de $125 \mathrm{~mm}$, para o estado do Piauí Fonte: Silva, C. O. da, (2016). 


\subsection{Zoneamento agrícola da cana-de-açúcar irrigada}

O zoneamento agrícola das cana-de-açúcar irrigada podem ser visualizadas nas figuras 13,14 e 15 .

No zoneamento agrícola da cana-de-açúcar irrigada observa-se que das cinco classes de lâminas brutas avaliadas, quatro apresentaram comportamento semelhantes nas três CAD's analisadas, ou seja, reduziram a sua área. Com reduções de aproximadamente $13 \%, 13 \%, 0 \%$ e $47 \%$, nas classes 800 a $1.160 \mathrm{~mm} ; 1.160$ a 1.520 $\mathrm{mm} ; 1.880$ a $2.240 \mathrm{~mm}$ e 2.240 a $2.600 \mathrm{~mm}$; respectivamente.

O intervalo de classe de lâminas brutas que apresentou maior restrição territorial, quanto a mecanização foi a de 2.240 a 2.600 mm, que corresponde a uma pequena área no semiárido piauiense que abrange os municípios de Acauã, Betânia do Piauí e Curral Novo. Embora os municípios citados consumam a maior lâmina bruta de irrigação, possuem uma ampla área apta a mecanização (53\%).

O único intervalo de classe que apresentou comportamento diferenciado entre as três CAD's foi o de 1.520 a $1.880 \mathrm{~mm}$. Na CAD's $75 \mathrm{~mm}$ a classe de lâmina bruta apresentou uma restrição a mecanização de aproximadamente $12 \%$ de sua área. Na CAD $100 \mathrm{~mm}$ o mesmo intervalo restringiu em aproximadamente $11 \%$ da sua área e na CAD $125 \mathrm{~mm}$ houve uma restrição em aproximadamente 10\%. Isso pode estar associado ao aumento da CAD, ou seja, na medida em que se aumentou a CAD, a capacidade de armazenamento de água do solo elevou, reduzindo a área de intervalo de classe de lâminas brutas maiores.

No ZAE elaborado por Manzatto et al. (2009) para o Brasil, que indica áreas aptas para seleção de terras potenciais para a expansão do seu cultivo de forma sustentável, apresentou uma pequena área da região sudeste, fronteira com o Maranhão, como área de aptidão media a expansão do cultivo da cana-de-açúcar no Piauí. Embora o ZAE apresente um cultivo de sequeiro, no presente para trabalho observou que essa área, encontra-se dentro da maior extensão territorial que abrange o menor intervalo de classe de lâmina bruta analisada (800 a $1.160 \mathrm{~mm})$. 

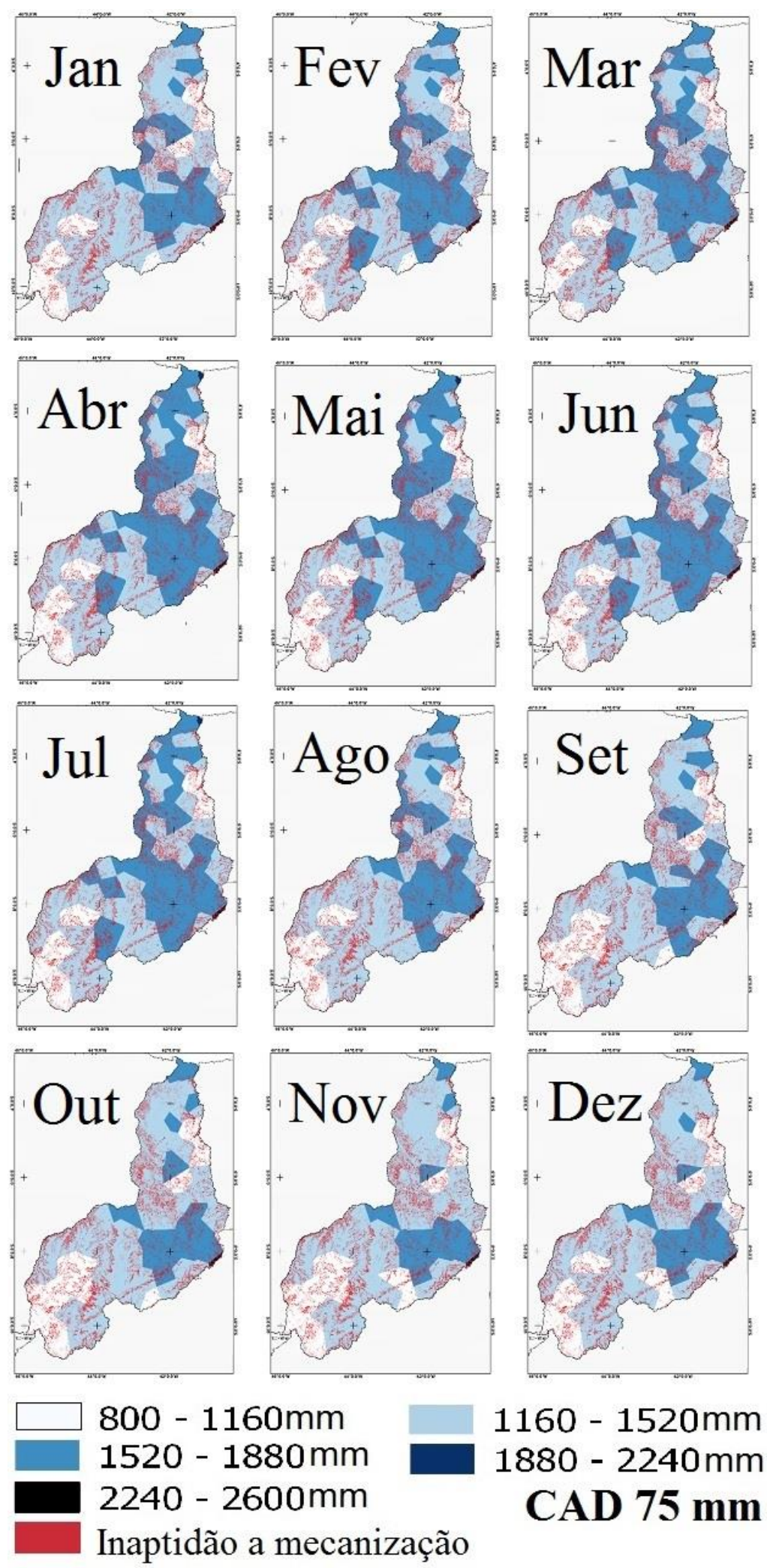

Figura 13 - Mapa do zoneamento agrícola para a cana-de-açúcar irrigada, para 12 meses de plantio em solos com capacidade de água disponível de $75 \mathrm{~mm}$, para o estado do Piauí

Fonte: Silva, C. O. da, (2016). 


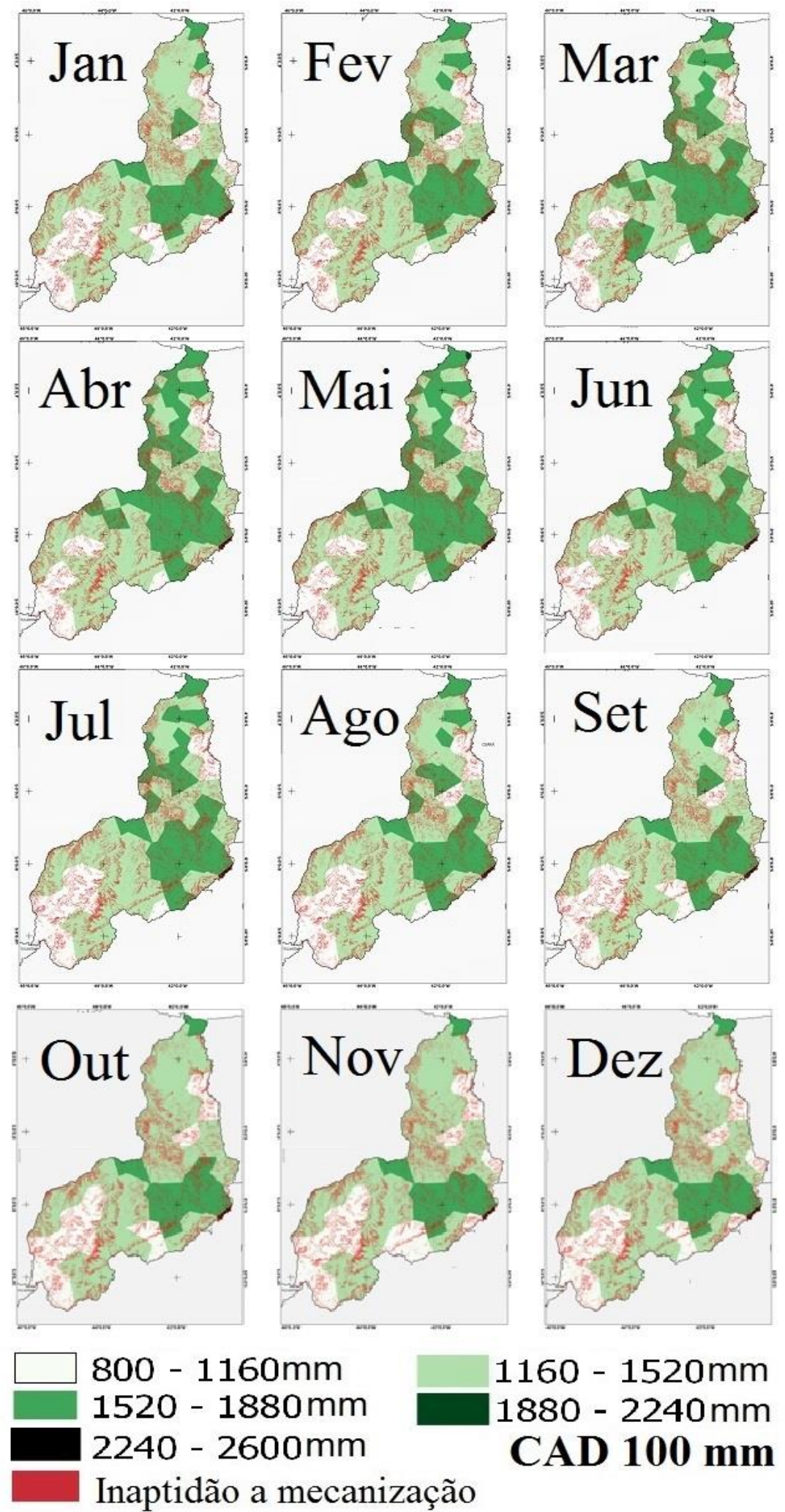

Figura 14 - Zoneamento agrícola para a cana-de-açúcar irrigada, para 12 meses de plantio em solos com capacidade de água disponível de $100 \mathrm{~mm}$, para o estado do Piauí Fonte: Silva, C. O. da, (2016). 

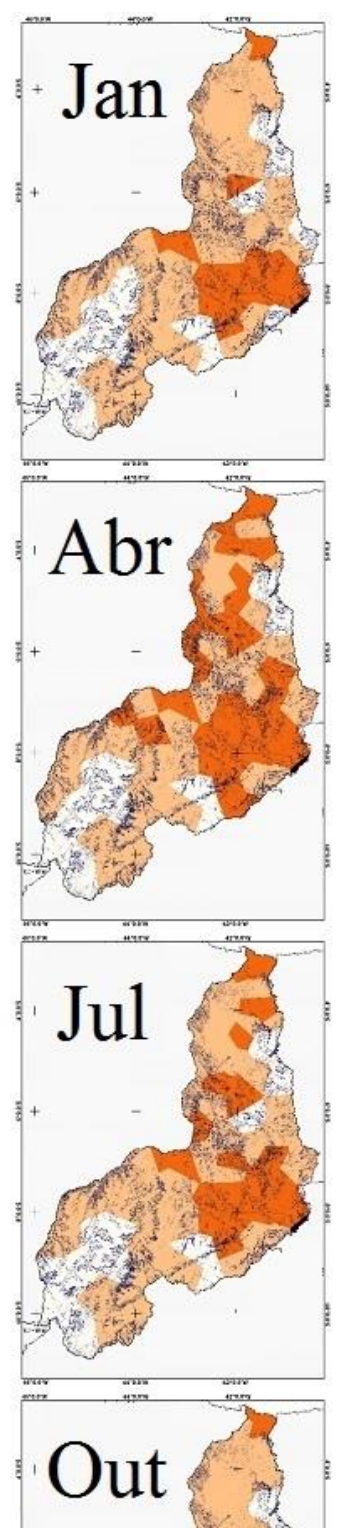

it+

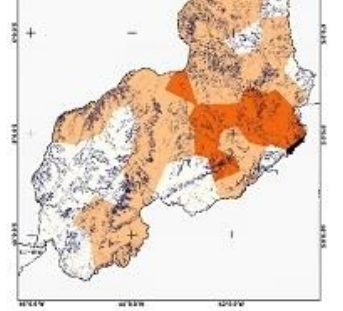

$800-1160 \mathrm{~mm}$

$1520-1880 \mathrm{~mm}$

2240 - $2600 \mathrm{~mm}$

\section{Inaptidão a mecanização}
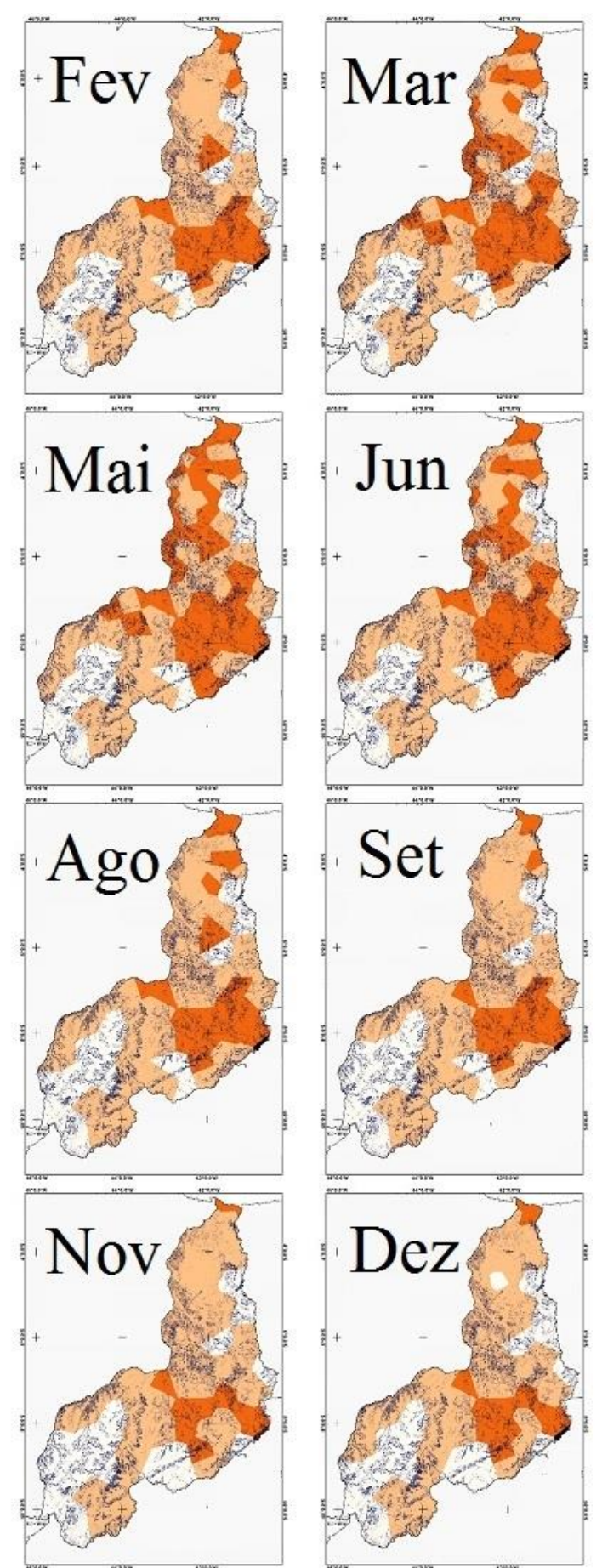

$1160-1520 \mathrm{~mm}$

$1880-2240 \mathrm{~mm}$

CAD 125 mm

Figura 15 - Zoneamento agrícola para a cana-de-açúcar irrigada, para 12 meses de plantio em solos com capacidade de água disponível de $125 \mathrm{~mm}$, para o estado do Piauí Fonte: Silva, C. O. da, (2016). 


\section{CONCLUSÕES}

O Estado do Piauí não possui restrições térmicas para o cultivo da cana-de-açúcar.

Os melhores meses de plantio com o menor consumo de lâmina bruta de irrigação forma de setembro a dezembro, observados no período seco da região, o que indica que o período de maior exigência hídrica da cultura ocorrerá no período de maior precipitação.

O zoneamento agrícola da cultura da cana-de-açúcar irrigada indicou áreas aptas e inaptas para fins de mecanização agrícola.

O uso das técnicas de geoprocessamento contribuiu de forma satisfatória nos resultados do zoneamento agrícola da cultura da cana-de-açúcar irrigada, embora o nível de detalhamento tenha sido reduzido em função escala trabalhada. 


\section{REFERÊNCIAS}

ALMEIDA, T. S.; CALIJURI, M. L.; PINTO, L. B. Zoneamento agroclimático da canade-açúcar para o estado de Minas Gerais com base em regressões múltiplas. Revista Brasileira de Meteorologia, São Paulo, v.28, n.3, 2013.

ANDRADE JÚNIOR, A. S. et al. Níveis de água, nitrogênio e potássio por gotejamento subsuperficial em cana-de-açúcar. Pesquisa Agropecuária Brasileira, Brasília, v.47, n.1, 2012.

ANDRADE JÚNIOR. A. S. et al. Atlas Climatológico do Estado do Piauí. Teresina: Embrapa Meio-Norte, 2004, 151 p. (Embrapa Meio-Norte. Documentos; 101).

ARAÚJO, J. L. L. (Coord.). Atlas Escolar do Piauí - geohistórico e cultural. João Pessoa: Editora Grafset, 2006.

ARAÚJO FILHO, J. C. et al. Levantamento de reconhecimento de baixa e média intensidade dos solos do Estado de Pernambuco. Rio de Janeiro: Embrapa Solos, 2000. (Embrapa Solos, Boletim de Pesquisa; 11).

BARROS, A. C. Utilização do modelo CANEGRO para estimativa da produtividade de cana-de-açúcar irrigada em diferentes regiões do Brasil. 2011. Tese (Doutor em Ciências) - Escola Superior de Agricultura "Luiz de Queiroz", Universidade de São Paulo, Piracicaba, 2011, 118p.

BERNADO, S. Impacto ambiental da irrigação no Brasil. 2008. Disponível em:<http://www.agr.feis.unesp.br/imagens/winotec_2008/winotec2008_palestras/Impac to_ambiental_da_irrigacao_no_Brasil_Salassier_Bernardo_winotec2008.pdf >. Acesso em: 02 ago. 2013.

BRASIL. Decreto $n^{\circ}$ 6.961, de 17 de setembro de 2009. Aprovação do Zoneamento Agroecológico da Cana-de-açúcar. Diário Oficial, Brasília, DF, 18 set. 2009. 
BRASIL. Lei 12.651 de 2012. Disponível em:

<http://www.planalto.gov.br/ccivil_03/_Ato2011-2014/2012/Lei/L12651.htm.> Acesso em: 13 nov. 2012.

BRASILa. Ministério da Agricultura e Abastecimento. Cana-de-açúcar. Disponível em: <http://www.agricultura.gov.br/vegetal/culturas/cana-de-acucar>. Acesso em: 17 out. 2015.

BRASILb. Ministério da Agricultura e Abastecimento. Cana-de-açúcar. Disponível em:<http://www.agricultura.gov.br/arq_editor/file/zoneamento_agricola/parametros $\% 20$ de\%20risco\%20climatico.pdf $>$. Acesso em: 08 set. 2015.

BRASIL. Ministério do Meio Ambiente (MMA). Panorama de desertificação do Estado do Piauí (Relatório de consultoria). Teresina, PI, nov. 2005. 21 p.

BRUNINI, O. Zoneamento de culturas bioenergéticas no estado de São Paulo. 2007. Artigo em Hypertexto. Disponível em:

<http://www.infobibos.com/Artigos/2007_3/zoneamento/index.htm>. Acesso em: 08 ago. 2014.

BRUNINI, O. et al. Zoneamento de culturas bioenergéticas no Estado de São Paulo: aptidão edafoclimática da cultura da cana-de-açúcar. Disponível em: <http://www.ciiagro.sp.gov.br/zoneamento/2008/ZONEAMENTO DE CULTURAS BIOENERGÉTICAS NO ESTADO DE SÃO PAULO_2.pdf>. Acesso em: 17 abr. 2010.

CAMARGO, A.P de et. al. Zoneamento da aptidão climática para culturas comerciais em zonas de cerrado. In: Simpósio sobre Cerrado, 4, Anais...São Paulo: Ed. USP, 1977. p. 89-105.

CARVALHO, C. M. de et al. Rendimento de açúcar e álcool da cana-de-açúcar submetida a diferentes níveis de irrigação. Revista Brasileira de Ciências Agrárias, Recife, v.4, n.1, p.72-77, jan.-mar. 2009.

CARVALHO, L. G. de et. al. Zoneamento da cana-de-açúcar e do eucalipto: aspectos geofísicos e bióticos. Disponível em: < http://www.zee.mg.gov.br/pdf/zoneamento_e_cenarios_exploratorios/4zoneamento_da_ cana_de_acucar_e_do_eucalipto_aspectos_geofisicos_e_bioticos.pdf $>$. Acesso em: 18 jul. 2015. 
CECILIO, R. A. et al. Zoneamento climático associado ao potencial de cultivo das Culturas do café, cana-de-açúcar e amendoim nas sub-bacias do Alto e Médio São Francisco em Minas Gerais. IN: XI SBSR - INPE. Belo Horizonte, Anais... Belo Horizonte, 2003, 39-45 p.

CGEEE - Centro de Gestão e Estudos Estratégicos. Estudo sobre as possibilidades e impactos da produção de grandes quantidades de etanol visando à substituição parcial de gasolina no mundo - Fase 2. Relatório Final. Brasília: Centro de Gestão e Estudos Estratégicos, 2009. Disponível em: www.cgee.org.br/atividades/redirect/3621. Acesso em: 22 set. 2015.

CHATTHA, M.U. Studies on growth, yield and quality of sugarcane (.) under different planting techniques, irrigation methods, water levels and mulch types. 2007. 162p. Tese (Doutorado em Filosofia e Agronomia) - Faculty of Agriculture, Faisalabad, 2007.

CIIAGRO - Centro integrado de informações agrometeorológicas. Zoneamento da cana-de-açúcar. Disponível em:〈http://www.ciiagro.sp.gov.br/znmt_cana.html〉. Acesso em: 30 ago. 2015.

CNPTIA - Embrapa Informática Agropecuária. Projetos em andamento: Resumo. Disponível em:

<https://www.macroprograma1.cnptia.embrapa.br/gestaomacrograma1/projetos/projetos -em-execucao/producao-sustentavel-da-cultura-da-cana-de-

acucar/portal_skins/custom/navegador.html>. Acesso em: 19 ago. 2015.

COSTA, M. C. G. et al. Distribuição radicular, estado nutricional e produção de colmos e de açúcar em soqueiras de dois cultivares de cana-de-açúcar em solos distintos.

Revista Brasileira de Ciências do Solo, v. 31, p. 1503-1514, 2007.

COLLICCHIO, E. Zoneamento edafoclimático e ambiental para a cana-de-açúcar e as implicações das mudanças climáticas do estado de Tocantins. 2008. 156 p. Tese (Doutorado em Ecologia Aplicada) - Escola Superior de Agricultura "Luiz de Queiroz", Universidade de São Paulo, Piracicaba, 2008.

DALRI, A.B.; CRUZ, R.L. Efeito da freqüência de irrigação subsuperficial por gotejamento no desenvolvimento da cana-de-açúcar (Saccharum spp.). Irriga, Botucatu, v. 7, n.1, p. 29-34, 2002.

DALRI, A.B.; CRUZ, R.L. Produtividade da cana-de-açúcar fertirrigada com N e K via gotejamento subsuperficial. Irriga, Botucatu, v. 28, n.3, p. 516-524, 2008. 
DANTAS NETO, J. et al. Resposta da cana-de-açúcar, primeira soca, a níveis de irrigação e adubação de cobertura. Revista Brasileira de Engenharia Agrícola e Ambiental, Campina Grande, v.10, n.2, p.283-288, 2006.

DATAGRO. Produção de açúcar no Nordeste tem queda de $28 \%$. Disponível em:< http://www.novacana.com/n/acucar/mercado/producao-acucar-nordeste-queda040314/>. Acesso em: 22 set. 2015.

DOORENBOS, J; KASSAM, A. H. Efeito da água no rendimento das culturas. Campina Grande: Universidade Federal da Paraíba, 2000. 221p.

FARIAS, C. H. A. et al. Índices de crescimento da cana-de-açúcar irrigada e de sequeiro no Estado da Paraíba. Revista Brasileira de Engenharia Agrícola e Ambiental, Campina Grande, v.12, n.4, p.356-362, 2008.

FARONI, C.E. Sistema radicular de cana-de-açúcar e identificação de raízes metabolicamente ativas. Dissertação (Mestrado em Agronomia) - Escola Superior de Agricultura “Luiz de Queiroz", Universidade Estadual Paulista, Piracicaba, 2005.

FERNANDES, P. G. Formas de plantio de mudas de cana-de-açúcar no sistema Meiosi. 2009. Dissertação (Mestrado em Produção Vegetal) - Universidade Estadual do Norte Fluminense "Darcy Ribeiro”, Campos dos Goitacazes, 2009.

FRANÇA, B. H. C.; JASINSKI, M. Cultivo de cana-de-açúcar. Dossiê Técnico. Rede de Tecnologia do Rio de Janeiro, Rio de Janeiro, 2007. 19 p. Disponível em:

<http://respostatecnica.org.br/dossie-tecnico/downloadsDT/Mjgw>. Acesso em: 10 set. 2014.

GAVA, G. J. G. et al. Produtividade e atributos tecnológicos de três cultivares de canade-açúcar irrigada por gotejamento subsuperficial. In: Congresso Nacional da STAB, 9, 2008. Anais. Maceió: STAB, 2008, p. 751-755.

GOMES, A. A. N.; ANDRADE JÚNIOR, A. S.; MEDEIROS, R. M. Evapotranspiração de Referência para o Estado do Piauí. Revista Brasileira de Engenharia Agrícola e Ambiental. Campina Grande, PB, v.9, n.4, p.560-564, 2005.

HERNANDEZ, F.B.T. Irrigação aumenta produtividade e qualidade da cana. Revista Campo e Negócio, Minas Gerais, p.78-79, 2006.

IBGE - EMBRAPA - Mapa de Solos do Brasil. Escala 1:5.000.000. Rio de Janeiro, IBGE, 2001. 
IBGE - INSTITUTO BRASILEIRO de GEOGRAFIA e ESTATÍSTICA. Censo 2010. Disponível em: < http://www.ibge.gov.br/estadosat/perfil.php?sigla=pi>. Acesso em: 11 ago. 2013.

IBGEa - INSTITUTO BRASILEIRO de GEOGRAFIA e ESTATÍSTICA. Mapas. Escala 1:250.000. Disponível em:

<http://portaldemapas.ibge.gov.br/portal.php\#homepage>. Acesso em: 28 set. 2015.

IBGEb - INSTITUTO BRASILEIRO de GEOGRAFIA e ESTATÍSTICA.

Levantamento Sistemático da Produção Agrícola. Disponível em:<

http://ftp.ibge.gov.br/Producao_Agricola/Levantamento_Sistematico_da_Producao_Agr icola_[mensal]/Fasciculo/lspa_201509.pdf >. Acesso em: 28 set. 2015.

IBGE - INSTITUTO BRASILEIRO de GEOGRAFIA e ESTATÍSTICA. Produção agrícola municipal - lavoura temporária - 2014. Disponível em: < http://www.cidades.ibge.gov.br/comparamun/compara.php?lang=\&coduf=22\&idtema= $149 \& \operatorname{codv}=v 41 \&$ search=piaui|uniao|sintese-das-informacoes-2014>. Acesso em: 23 mar. 2015.

LACERDA, C. F. de; ENÉAS FILHO, J.; PINHEIRO, C. B. Fisiologia vegetal (apostila). 2007. Disponível em:< http://www.fisiologiavegetal.ufc.br/APOSTILA/>. Acesso em: 23 set. 2012.

LANDELL, M. G. de A. et al. Seleção de novas variedades de cana-de-açúcar e seu manejo de produção. Encarte do Informações Agronômicas, Geórgia, n. 110, jun. 2005.

LIMA, M. G. de; RIBEIRO, V. Q. Equações de estimativa da temperatura do ar para o Estado do Piauí, Brasil. Revista Brasileira de Agrometeorologia, Santa Maria, v.6, n.2, p.221-227, 1998.

MANZATTO, C.V. et al. Zoneamento agroecológico da cana- de-açúcar. Rio de Janeiro: Embrapa solos, 2009. 55p.

MARIN, F.R. Clima. Disponível em:

$<$ http://www.agencia.cnptia.embrapa.br/gestor/cana deaçúcar/arvore/CONTAG01_10_711200516716.html>. Acesso em: 25 ago. 2015.

MARIN, F.R. Zoneamento agrícola. Disponível em: < https://www.agencia.cnptia.embrapa.br/gestor/cana-deacucar/arvore/CONTAG01_64_22122006154840.html>. Acesso em: 30 jan. 2014. 
MAPA - Ministério da Agricultura Pecuária e Abastecimento. Zoneamento de risco climático. Disponível em: < http://www.agricultura.gov.br/politicaagricola/zoneamento-agricola>. Acesso em: 30 ago. 2010.

MEDEIROS, R. M. de. Estudo agrometeorológico para o estado do Piauí. 2007, 123p. 2007.

MEDEIROS, R. M. de et al. Classificação climática e zoneamento agroclimático para o município de Amarante - PI. Revista Brasileira de Agricultura Irrigada, Fortaleza, v.7, n. 2, p. 170 - 180, 2013.

MEDEIROS, R. M. de et al. Estudo da evapotranspiração de referência mensal e anual sobre a bacia hidrográfica do rio Uruçuí Preto - Piauí, Brasil. IN: CONGRESSO DE EDUCAÇÃO AGRÍCOLA SUPERIOR, 9, 2014, Areia, Anais, Areia: ABEAS, 2014.

MEDINA, C. de C. et al. Crescimento radicular e produtividade de cana-de-açúcar em função de doses de vinhaça em fertirrigação. Semina: Ciências Agrárias, Londrina, v. 23, n. 2, p. 179-184, jul./dez. 2002.

MORAES, A. M de. Capacidade de uso da terra no município de Teresina: elementos para uma política de conservação dos recursos. Dissertação (Mestrado em Desenvolvimento e meio ambiente) - Universidade Federal do Piauí, Teresina, 2004. $153 p$.

MOUSINHO, F. E. P. Viabilidade econômica da irrigação do feijão caupi no Estado do Piauí. 2005. Tese (Doutorado em Agronomia) - Escola Superior de Agricultura "Luiz de Queiroz", Universidade de São Paulo, Piracicaba, 2005. 125p.

MOUSINHO, F. E. P.; ANDRADE JÚNIOR, A. S. de; FRIZZONE, J. A. Viabilidade econômica do cultivo irrigado do feijão-caupi no Estado. Acta Sci. Agron, Maringá, v. 30, n. 1, p. 139-145, 2008.

OLIVEIRA, E. C. A. de et al. Produtividade, eficiência de uso da água e qualidade tecnológica de cana-de-açúcar submetida a diferentes regimes hídricos. Pesquisa agropecuária brasileira, Brasília, v.46, n.6, p.617-625, jun., 2011.

OLIVEIRA, J. R. Espacialização das lâminas de irrigação para a cultura da melancia no Estado do Piauí. 2014. Dissertação (Mestrado em Agronomia) Universidade Federal do Piauí, Teresina, 2014. 84 p. 
PEREIRA, A. R.; ANGELUCCI, L. R.; SENTELHAS, P. C. Agrometeorologia: fundamentos e aplicações práticas. Editora Agropecuária, 2002. 478p.

PEREIRA, L.S. et al. Irrigation scheduling strategies for cotton to cope with water scarcity in the Fergana Valley, Central Asia. Agricultural water Management, v. 96, p. 723-735, 2009.

PEREIRA, A. R.; VILLA NOVA, N. A.; SEDIYAMA, G. C. Evapo(transpi)ração. Piracicaba: ESALQ/USP, 1997. 183p.

PIAUÍ, Secretaria Estadual do Meio Ambiente e Recursos Hídricos. Programa de Ação Estadual de Combate à Desertificação - PAEPI. Teresina: Ministério do Meio Ambiente / Secretaria Estadual do Meio Ambiente e Recursos Hídricos, 2010. 229p.

PIBH - Plano de integração das bacias hidrográficas do Piauí: aproveitamento das infraestruturas existentes, irrigação e abastecimento hídrico da fronteira seca estadual. Etapa II - Planejamento: compatibilização e articulação das alternativas. Relatório Final. 2008. 268 p.

QUANTUM GIS DEVELOPMENT TEAM, 2015. Geographic Information System User Guide. Open Source Geospatial Foundation Project. Disponível em: $<$ http://qgis.osgeo.org>. Acesso em: 14 mar. 2015.

RAMALHO FILHO, A.; BEEK, K. J. Sistema de avaliação da aptidão agrícola das terras. 3.ed. Rio de Janeiro: EMBRAPA-CNPS, 1995. 65p.

ROSSETTO, R. Árvore do conhecimento cana-de-açúcar: queima. Disponível em: $<$ http://www.agencia.cnptia.embrapa.br/gestor/cana-deacucar/arvore/CONTAG01_92_22122006154841.html_. Acesso em: 12 ago. 2015.

ROSSIN, B.G.; TOMMASELLI, J.T.G. Efeitos do clima sobre a produção da canade-açúcar na região de Presidente Prudente - SP. Disponível em: < http://egal2009.easyplanners.info/area07/7079_Bruna_Bruna_Gomes_Rossin.pdf >. Acesso em 24 ago. 2010.

PIAUÍ. SEMARH - Secretaria de Estado do Meio Ambiente e Recurso Hídricos. Panorama de dessertificação do Estado do Piauí. 2005. Disponível em: < http://www.mma.gov.br/estruturas/sedr_desertif/_arquivos/panorama_piaui.pdf>. Acesso em: 10 abr. 2014.

SANTOS, H. G. dos et al. Mapa de solos do brasil (pdf). Embrapa solos núcleo de geométricas - NGEO - Embrapa Solos, 2011. Disponível em: 
<http://mapoteca.cnps.embrapa.br/download/obj/ok1754.pdf >. Acesso em: 09 mai. 2015.

SILVA, M. de A.; GAVA, G.J.C.; AGUIAR, F.L.; KRONTAL, Y.; SILVA, R.C. Yield potential of drip irrigated sugarcane varieties. In: AGRONOMY WOKSHOP Sugarcane production: Integration among sugar, alcohol, residue cycling and sustainability, 2009, Uberlândia, MG, Brazil. Resumos... Uberlândia: International Society of Sugar Cane Technologists, p. 13 -14, 2009.

SILVA, V. de P. R. da et al. Risco climático da cana-de-açúcar cultivada na região Nordeste do Brasil. Revista Brasileira de Engenharia Agrícola e Ambiental, Campina Grande, PB, v.17, n.2, p.180-189, 2013.

TEODORO, I. et al. Avaliação de variedades de cana-de-açúcar irrigadas por gotejamento. IN: CONGRESSO BRASILEIRO DE AGROMETEOROLOGIA, 16, 2009, Anais... Belo Horizonte, MG, 2009.

THORNTHWITE, C. W. An Approach toword a rational classification of climate. Geografical Riview, v.38, n.1, p55-94, 1948.

THORNTHWAITE, C. W.; MATHER, J. R. 1995. The water balance. Centerton, NJ, USA: Drexel Institute of Technology, 1955.

TORQUATO, S. A.; JESUS, K. R. E. de; ZORZO, C. R. B. Inovações no sistema de produção de cana-de-açúcar: uma contribuição do Protocolo Agroambiental para a região de Piracicaba, Estado de São Paulo. Informações Econômicas, São Paulo, v. 45, n. 2, p. 30-43. 2015.

TOWNSEND, C. R. Recomendações técnicas para o cultivo da cana-de-açúcar forrageira em Rondônia. EMBRAPA-CPAF, Rondônia, n. 21, p. 1-5, nov. 2000.

UNICA - União das Indústrias da Cana-de-açúcar. Produção. Disponível em:< http://www.unicadata.com.br/historico-de-producao-e-

moagem.php?idMn $=31 \&$ tipoHistorico $=2 \&$ acao $=$ visualizar\&idTabela $=1621 \&$ produto $=\mathrm{c}$ ana\&safraIni $=2013 \% 2 \mathrm{~F} 2014 \&$ safraFim $=2014 \% 2 \mathrm{~F} 2015 \&$ estado $=\mathrm{RS} \% 2 \mathrm{CSC} \% 2 \mathrm{CPR} \% 2$ CSP $\% 2 \mathrm{CRJ} \% 2 \mathrm{CMG} \% 2 \mathrm{CES} \% 2 \mathrm{CMS} \% 2 \mathrm{CMT} \% 2 \mathrm{CGO} \% 2 \mathrm{CDF} \% 2 \mathrm{CBA} \% 2 \mathrm{CSE} \% 2 \mathrm{CAL}$ $\% 2 \mathrm{CPE} \% 2 \mathrm{CPB} \% 2 \mathrm{CRN} \% 2 \mathrm{CCE} \% 2 \mathrm{CPI} \% 2 \mathrm{CMA} \% 2 \mathrm{CTO} \% 2 \mathrm{CPA} \% 2 \mathrm{CAP} \% 2 \mathrm{CRO} \% 2 \mathrm{C}$ AM\%2CAC\%2CRR>. Acesso em: 12 set. 2015. 
VAREJÃO - SILVA, M. A.; BARROS, A. H. C. Zoneamento de aptidão climática do Estado de Pernambuco para três distintos cenários pluviométricos. Recife, 2002. Disponível em: <www.itep.br/meteorologia/lamepe/zoneamento/docs/doc_can.doc>. Acesso em: 15 abr. 2010.

VASCONCELOS, A. C. M. de; DINARDO-MIRANDA, L. L. Dinâmica do desenvolvimento radicular da cana-de-açúcar e implicações no controle de nematoides. Editora Adonis, Americana, 56 p, 2010.

WALDHEIM, P. V. et al. Zoneamento Climático da Cana-de-Açúcar, da Laranja e do Algodão Herbáceo para a Região Nordeste do Brasil. Anuário do Instituto de Geociências: UFRJ. v 29. p. 30-43, 2006. 
APÊNDICE 
Apêndice 1 - Postos pluviométricos, utilizados no estudo, de onde foram extraídos valores diários de precipitação, com suas respectivas localizações geográfica, utilizados no estudo.

\begin{tabular}{|c|c|c|c|c|}
\hline Ordem & Postos & Latitude (Sul) & Longitude (Oeste) & Altitude (m) \\
\hline 1 & Alívio & $05^{\circ} 27^{\prime}$ & $41^{\circ} 06^{\prime}$ & 730 \\
\hline 2 & Alto Alegre & $04^{\circ} 01^{\prime}$ & $41^{\circ} 27^{\prime}$ & 80 \\
\hline 3 & Alto Parnaíba & $09^{\circ} 08^{\prime}$ & $45^{\circ} 56^{\prime}$ & 220 \\
\hline 4 & Altos & $05^{\circ} 02^{\prime}$ & $42^{\circ} 28^{\prime}$ & 160 \\
\hline 5 & Amarante & $06^{\circ} 15^{\prime}$ & $42^{\circ} 51^{\prime}$ & 72 \\
\hline 6 & Anísio de Abreu & $09^{\circ} 09^{\prime}$ & $42^{\circ} 59^{\prime}$ & 460 \\
\hline 7 & Aroazes & $06^{\circ} 07^{\prime}$ & $41^{\circ} 47^{\prime}$ & 400 \\
\hline 8 & Assunção & $05^{\circ} 52^{\prime}$ & $41^{\circ} 03^{\prime}$ & 480 \\
\hline 9 & Barras & $04^{\circ} 15^{\prime}$ & $42^{\circ} 18^{\prime}$ & 75 \\
\hline 10 & Barroquinha & $02^{\circ} 59^{\prime}$ & $41^{\circ} 05^{\prime}$ & 5 \\
\hline 11 & Beneditinos & $05^{\circ} 27^{\prime}$ & $42^{\circ} 22^{\prime}$ & 80 \\
\hline 12 & Bocaína & $06^{\circ} 54^{\prime}$ & $41^{\circ} 19^{\prime}$ & 250 \\
\hline 13 & Bom Jardim & $09^{\circ} 21^{\prime}$ & $42^{\circ} 25^{\prime}$ & 600 \\
\hline 14 & Bom Jessus do Itaueira & $07^{\circ} 05^{\prime}$ & $43^{\circ} 01^{\prime}$ & 95 \\
\hline 15 & Bom Princípio & $03^{\circ} 15^{\prime}$ & $41^{\circ} 38^{\prime}$ & 50 \\
\hline 16 & Boqueirão dos Felipes & $09^{\circ} 45^{\prime}$ & $45^{\circ} 40^{\prime}$ & 580 \\
\hline 17 & Brejo & $09^{\circ} 24^{\prime}$ & $45^{\circ} 14^{\prime}$ & 550 \\
\hline 18 & Buriti dos Lopes & $03^{\circ} 11^{\prime}$ & $41^{\circ} 52^{\prime}$ & 23 \\
\hline 19 & Cachoeira do Roberto & $08^{\circ} 38^{\prime}$ & $41^{\circ} 09^{\prime}$ & 630 \\
\hline 20 & Campos Santo & $08^{\circ} 19^{\prime}$ & $40^{\circ} 34^{\prime}$ & 34 \\
\hline 21 & Cantinho & $05^{\circ} 51^{\prime}$ & $42^{\circ} 29^{\prime}$ & 150 \\
\hline 22 & Canto do Buriti & $08^{\circ} 07^{\prime}$ & $42^{\circ} 57^{\prime}$ & 280 \\
\hline 23 & Capitão de Campos & $04^{\circ} 28^{\prime}$ & $41^{\circ} 57^{\prime}$ & 120 \\
\hline 24 & Cocal de Telha & $03^{\circ} 29^{\prime}$ & $41^{\circ} 34^{\prime}$ & 220 \\
\hline 25 & Conceição do Canindé & $07^{\circ} 54^{\prime}$ & $41^{\circ} 34^{\prime}$ & 249 \\
\hline 26 & Conceição II & $08^{\circ} 46^{\prime}$ & $44^{\circ} 24^{\prime}$ & 390 \\
\hline 27 & Curral Novo & $09^{\circ} 01^{\prime}$ & $41^{\circ} 58^{\prime}$ & 350 \\
\hline 28 & Esperantina & $03^{\circ} 54^{\prime}$ & $42^{\circ} 14^{\prime}$ & 50 \\
\hline 29 & Fazenda Alegria & $04^{\circ} 41^{\prime}$ & $42^{\circ} 17^{\prime}$ & 190 \\
\hline 30 & Fazenda Barra & $10^{\circ} 03^{\prime}$ & $45^{\circ} 54^{\prime}$ & 490 \\
\hline 31 & Fazenda Barreiros & $09^{\circ} 59^{\prime}$ & $44^{\circ} 37^{\prime}$ & 310 \\
\hline 32 & Fazenda Boa Esperança & $05^{\circ} 17^{\prime}$ & $41^{\circ} 44^{\prime}$ & 195 \\
\hline 33 & Fazenda Bravo & $07^{\circ} 08^{\prime}$ & $40^{\circ} 54^{\prime}$ & 490 \\
\hline 34 & Fazenda Bugiu & $08^{\circ} 12^{\prime}$ & $41^{\circ} 58^{\prime}$ & 250 \\
\hline 35 & Fazenda Ipiranga & $05^{\circ} 01^{\prime}$ & $42^{\circ} 05^{\prime}$ & 140 \\
\hline 36 & Fazenda Lustosa & $04^{\circ} 20^{\prime}$ & $42^{\circ} 33^{\prime}$ & 90 \\
\hline
\end{tabular}


Apêndice 1 - Postos pluviométricos, utilizados no estudo, de onde foram extraídos valores diários de precipitação, com suas respectivas localizações geográfica, utilizados no estudo (continuação).

\begin{tabular}{|c|c|c|c|c|}
\hline Ordem & Postos & Latitude (Sul) & Longitude (Oeste) & Altitude (m) \\
\hline 37 & Fazenda Madeira Cortada & $04^{\circ} 29^{\prime}$ & $41^{\circ} 10^{\prime}$ & 600 \\
\hline 38 & Fazenda Prevenido & $03^{\circ} 34^{\prime}$ & $41^{\circ} 44^{\prime}$ & 120 \\
\hline 39 & Fazenda Veneza & $05^{\circ} 35^{\prime}$ & $43^{\circ} 02^{\prime}$ & 70 \\
\hline 40 & Formosa & $07^{\circ} 34^{\prime}$ & $42^{\circ} 10^{\prime}$ & 230 \\
\hline 41 & Gado Bravo & $06^{\circ} 56^{\prime}$ & $43^{\circ} 50^{\prime}$ & 180 \\
\hline 42 & Inhuma & $06^{\circ} 40^{\prime}$ & $41^{\circ} 42^{\prime}$ & 300 \\
\hline 43 & Itainópolis & $07^{\circ} 24^{\prime}$ & $41^{\circ} 31^{\prime}$ & 210 \\
\hline 44 & Jaicós & $07^{\circ} 22^{\prime}$ & $41^{\circ} 08^{\prime}$ & 255 \\
\hline 45 & Japecanga & $08^{\circ} 44^{\prime}$ & $43^{\circ} 56^{\prime}$ & 240 \\
\hline 46 & Jenipapeiro & $10^{\circ} 39^{\prime}$ & $45^{\circ} 11^{\prime}$ & 510 \\
\hline 47 & José de Freitas & $04^{\circ} 45^{\prime}$ & $42^{\circ} 35^{\prime}$ & 130 \\
\hline 48 & Luiz Corrêia & $02^{\circ} 53^{\prime}$ & $41^{\circ} 40^{\prime}$ & 10 \\
\hline 49 & Luzilândia & $03^{\circ} 27^{\prime}$ & $42^{\circ} 22^{\prime}$ & 20 \\
\hline 50 & Matias Olímpio & $03^{\circ} 43^{\prime}$ & $42^{\circ} 33^{\prime}$ & 50 \\
\hline 51 & Miguel Alves & $04^{\circ} 10^{\prime}$ & $42^{\circ} 54^{\prime}$ & 34 \\
\hline 52 & Morais & $07^{\circ} 39^{\prime}$ & $40^{\circ} 24^{\prime}$ & 570 \\
\hline 53 & Moreira & $08^{\circ} 37^{\prime}$ & $42^{\circ} 08^{\prime}$ & 250 \\
\hline 54 & Nazaré do Piauí & $06^{\circ} 58^{\prime}$ & $42^{\circ} 40^{\prime}$ & 180 \\
\hline 55 & Oeiras & $07^{\circ} 01^{\prime}$ & $42^{\circ} 08^{\prime}$ & 170 \\
\hline 56 & Olho D’Água Grande & $04^{\circ} 15^{\prime}$ & $41^{\circ} 17^{\prime}$ & 330 \\
\hline 57 & Palmeirais & $05^{\circ} 58^{\prime}$ & $43^{\circ} 04^{\prime}$ & 85 \\
\hline 58 & Patos & $07^{\circ} 40^{\prime}$ & $41^{\circ} 15^{\prime}$ & 260 \\
\hline 59 & Pio IX & $06^{\circ} 50^{\prime}$ & $40^{\circ} 37^{\prime}$ & 550 \\
\hline 60 & Piracuruca & $03^{\circ} 56^{\prime}$ & $41^{\circ} 43^{\prime}$ & 70 \\
\hline 61 & Piripiri & $04^{\circ} 17^{\prime}$ & $41^{\circ} 47^{\prime}$ & 160 \\
\hline 62 & Piripirizinho & $07^{\circ} 25^{\prime}$ & $43^{\circ} 11^{\prime}$ & 230 \\
\hline 63 & Porto & $03^{\circ} 54^{\prime}$ & $42^{\circ} 43^{\prime}$ & 32 \\
\hline 64 & Puca & $08^{\circ} 03^{\prime}$ & $43^{\circ} 39^{\prime}$ & 280 \\
\hline 65 & Puca II & $08^{\circ} 24^{\prime}$ & $44^{\circ} 24^{\prime}$ & 390 \\
\hline 66 & Retiro & $04^{\circ} 40^{\prime}$ & $41^{\circ} 28^{\prime}$ & 530 \\
\hline 67 & Riacho da Mata & $04^{\circ} 56^{\prime}$ & $40^{\circ} 45^{\prime}$ & 290 \\
\hline 68 & Riacho do Mendes & $07^{\circ} 38^{\prime}$ & $43^{\circ} 40^{\prime}$ & 170 \\
\hline 69 & Ribeiro Gonçalves & $07^{\circ} 32^{\prime}$ & $45^{\circ} 14^{\prime}$ & 150 \\
\hline 70 & Saco dos Reis & $07^{\circ} 14^{\prime}$ & $42^{\circ} 11^{\prime}$ & 230 \\
\hline 71 & Salinas & $08^{\circ} 06^{\prime}$ & $42^{\circ} 34^{\prime}$ & 170 \\
\hline 72 & Sangue & $07^{\circ} 34^{\prime}$ & $44^{\circ} 43^{\prime}$ & 170 \\
\hline 73 & Santa Cruz dos Milagres & $05^{\circ} 49^{\prime}$ & $41^{\circ} 58^{\prime}$ & 80 \\
\hline 74 & São João da Serra & $05^{\circ} 30^{\prime}$ & $41^{\circ} 55^{\prime}$ & 180 \\
\hline 75 & São Pedro & $06^{\circ} 27^{\prime}$ & $41^{\circ} 20^{\prime}$ & 260 \\
\hline 76 & Serra Vermelha & $07^{\circ} 51^{\prime}$ & $44^{\circ} 10^{\prime}$ & 360 \\
\hline 77 & Serra Vermelha II & $07^{\circ} 56^{\prime}$ & $40^{\circ} 53^{\prime}$ & 280 \\
\hline
\end{tabular}


Apêndice 1 - Postos pluviométricos, utilizados no estudo, de onde foram extraídos valores diários de precipitação, com suas respectivas localizações geográfica, utilizados no estudo (continuação).

\begin{tabular}{llrrc}
\hline Ordem & Postos & Latitude (Sul) & Longitude (Oeste) & Altitude $(\mathrm{m})$ \\
\hline 78 & Sete Lagoas & $08^{\circ} 27^{\prime}$ & $41^{\circ} 42^{\prime}$ & 380 \\
79 & Sítio Estação & $08^{\circ} 47^{\prime}$ & $42^{\circ} 44^{\prime}$ & 510 \\
80 & Socorro do Piauí & $07^{\circ} 48^{\prime}$ & $42^{\circ} 30^{\prime}$ & 180 \\
81 & Tasso Fragoso & $08^{\circ} 28^{\prime}$ & $45^{\circ} 46^{\prime}$ & 191 \\
82 & Teresina & $05^{\circ} 05^{\prime}$ & $42^{\circ} 49^{\prime}$ & 72 \\
83 & Tucuns & $07^{\circ} 07^{\prime}$ & $44^{\circ} 20^{\prime}$ & 130 \\
84 & União & $04^{\circ} 35^{\prime}$ & $42^{\circ} 52^{\prime}$ & 50 \\
85 & Várzea Grande & $06^{\circ} 34^{\prime}$ & $42^{\circ} 13^{\prime}$ & 270 \\
86 & Veados & $06^{\circ} 49^{\prime}$ & $43^{\circ} 30^{\prime}$ & 85 \\
87 & Vereda da Glória & $09^{\circ} 45^{\prime}$ & $44^{\circ} 52^{\prime}$ & 290 \\
\hline
\end{tabular}

